\title{
A presença dos moinhos hidráulicos no Brasil
}

\section{Francisco de Carvalho Dias de Andrade ${ }^{1}$}

RESUMO: $O$ presente artigo pretende recolocar a importância do estudo da história da técnica para o entendimento das estruturas agrárias e das paisagens culturais brasileiras. Investigando a história dos moinhos hidráulicos no país, procura-se apontar o potencial existente no estudo da cultura material a eles associada e em uma abordagem histórica da terminologia. Desse modo três grandes questões são abordadas: o papel dos moinhos nas estruturas agrárias do interior do país, as raízes mediterrânicas das técnicas envolvidas na construção desses maquinismos e a importância das mós remanescentes.

PALAVRAS-CHAVE: Moinhos hidráulicos. História da técnica. Patrimônio cultural.

ABSTRACT: This article seeks to recall the importance of the study of the history of techniques for understanding the agrarian structures and cultural landscapes of Brazil. Through the history of hydraulic mills in the country, it seeks to point out the existing potential in the material culture associated and in a historical approach to terminology. Thus three major issues are addressed: the role of the mills in the agrarian structures of the hinterlands, the Mediterranean roots of the techniques involved in the construction of these machines and the importance of remaining millstones.

KEY-WORDS: Hydraulic mills. History of techniques. Cultural heritage.

A presença dos moinhos hidráulicos no Brasil ${ }^{2}$

$\bigcirc$ velho moinho hidráulico europeu, cujas origens remontam ao Mediterrâneo helenístico, foi um dos elementos mais marcantes nas paisagens rurais de quase todos os estados do Centro-Sul do Brasil. Sua presença desde há muito é notada nessa ampla região, seja em grandes fazendas ou em pequenos sítios mais prósperos. Na realidade, os moinhos se fizeram presentes desde o início do

\begin{abstract}
1. Doutorando do programa de pós-graduação em História da Arte da UNICAMP. Bolsista de doutorado da FAPESP. E-mail: <chicodandrade@ gmail.com>.

2. Logo após a conclusão deste artigo, veio a notícia da morte de João Evangelista de Faria, um dos grandes defensores da cultura do Vale do Paraíba. Dedico, assim, este estudo ao João Rural, como era conhecido, com quem aprendi a riqueza polissêmica das lides agrícolas.
\end{abstract}


3. Tal expressão parece ter sido utilizada pela primeira vez por Maria Isaura Pereira de Queiroz, em estudos de sociologia rural brasileira. Sempre careceu, no entanto, de critérios mais sólidos que fundamentassem melhor seu emprego, que, em verdade, nunca pretendeu se referir à cultura material. Assim, seu uso, aqui, faz-se também sem maiores preocupações. Pretende apenas indicar certas particularidades dos habitats rurais dessa região, já visíveis a observadores externos desde épocas bastante recuadas.Ver Maria Isaura Pereira de Queiroz (1973, p. 8).

4. Cf. Jean Baptiste Debret apud Júlio Bandeira e Pedro Corrêa Lago (2009, p. 197). Os moinhos do Morro da Conceição aparecem ao menos em duas peças da iconografia carioca: Ver o panorama feito em 1821 por Henry Chamberlaind View of the city of Rio de Janeiro taken from the Anchorage, $\mathrm{e}$ a prancha de Debret, em sua Voyage pittoresque, "Vista geral da cidade do Rio de Janeiro tomada do Convento de São Bento". povoamento dessa vasta área, excetuando algumas poucas zonas de ocupação mais precoce, como a orla litorânea.

Os moinhos d'água desempenharam importante papel na vida humana nessas paragens - só abalado nas últimas décadas, quando a industrialização e urbanização do país deixaram de ser um fenômeno circunscrito às grandes capitais. Ainda assim, algumas poucas localidades mais afastadas mantêm seus moinhos operantes. E por mais valiosos que os remanescentes sejam, eles só podem fornecer, contudo, um frágil indício do enorme peso que esses maquinismos tiveram na conformação das antigas estruturas agrárias dessa vasta região.

Em realidade, a presença dos moinhos d'água no interior do Brasil é um dos melhores indícios daquilo que os estudos da cultura material brasileira chamavam, um tanto impropriamente, de "civilização caipira" ${ }^{3}$. Os antigos moinhos d'água serviriam como um bom indicador desse fenômeno não só pela sua grande difusão nessa área, mas principalmente pela enorme estabilidade de seu agenciamento técnico, que se manteve o mesmo tanto no espaço como no tempo.

Apenas dois cenários fugiriam dessa regra: um como fato realmente excêntrico e outro como uma inovação técnica, que mais aprimorou do que transformou o papel dos moinhos no Brasil. $O$ primeiro refere-se aos moinhos de trigo cuja presença chegou a ser recorrente em dois momentos e regiões distintas: no Planalto Paulista no século XVII e nas zonas de imigração na Região Sul nos séculos XIX e XX. O caso dos moinhos do século XVII será analisado adiante de forma mais demorada. Já os moinhos de trigo do sul do país demandariam um estudo com enfoques mais particularizados e só serão aqui referidos de maneira secundária.

O segundo cenário trata da presença de outros tipos de moinho que não o pequeno moinho de roda horizontal, ou moinho de rodízio, claramente distinguível no cenário nacional das azenhas, atafonas e moinhos de vento aqui por ventura instalados. A existência de moinhos de vento foi realmente um dos mais raros fatos no Brasil. Apenas dois casos são conhecidos: o mais antigo seria um moinho de vento cujas ruínas ainda existem em Ouro Preto, no Morro da Queimada, próximo à capela de São João Batista (Figura 1). É provável, contudo, que se tratasse de um maquinismo destinado a triturar rochas nas operosas lavras ali existentes até 1720 - quando o local foi arrasado após a revolta de Felipe dos Santos.

Existem também referências a moinhos de vento que teriam funcionado na cidade do Rio de Janeiro até os primeiros anos do século XIX. A mais destacada menção a moinhos eólicos na cidade é de Jean Baptiste Debret, que encontrou dois deles construídos "no morro perto do convento de São Bento" - referindo-se ao Morro da Conceição4.

As atividades desses moinhos de vento cariocas não teriam sido muito intensas, nem durado muito tempo. Foram construídos, provavelmente, em meados do século XVIII para garantir o abastecimento da cidade em caso de ataque e teriam tido um funcionamento apenas intermitente. Quando a decadência da 
mineração deixou para trás os tempos em que o Rio de Janeiro era o porto mais cobiçado dos mares do Sul, tais moinhos foram rapidamente abandonados ${ }^{5}$.

No caso das azenhas - moinhos movidos por uma roda d'água vertical e providos de um sistema de engrenagens que transforma o vetor da rotação -, sua presença em terras brasileiras só se deu a partir da imigração europeia do século XIX. E, de fato, as azenhas correspondem ao tipo de moinho mais comum no Sul. Os moinhos verticais sulinos, entretanto, distanciam-se da tradição ibérica das azenhas, conforme pode-se ver no caso de um moinho existente em Gramado, no Rio Grande do Sul (Figura 2). Trata-se antes de uma manifestação da herança técnica de italianos, alemães e europeus do Leste do que de obras filiadas à tradição artesanal ibérica.

E se no sul do país, a forte presença do trigo - que nunca deixou de ser cultivado pelos imigrantes e seus descendentes - fez com que seus moinhos fossem capazes de moer tanto o cereal europeu quanto o milho americano, o mesmo não se deu no Sudeste. Em São Paulo, onde também não se conheceu moinhos verticais até então, as azenhas quase nunca moeram qualquer outro cereal que não o milho. A razão para tanto deve-se à maior presença em São Paulo de imigrantes italianos,
5. Outro desses moinhos, certamente, é o que pode ser visto no interior da fortaleza da Ilha das Cobras, no panorama da cidade elaborado por Dom Miguel Angelo Blasco, por volta de 1760. Teria uma função claramente estratégica, a qual se pode atribuir a singular solução de recorrer ao vento - de modo nenhum inapropriada, tendo em vista as fortes brisas marítimas. Sua origem talvez remonte à reforma das fortificações da cidade, empreendida após o ataque do corsário francês Duguay-Troin, em 1711.

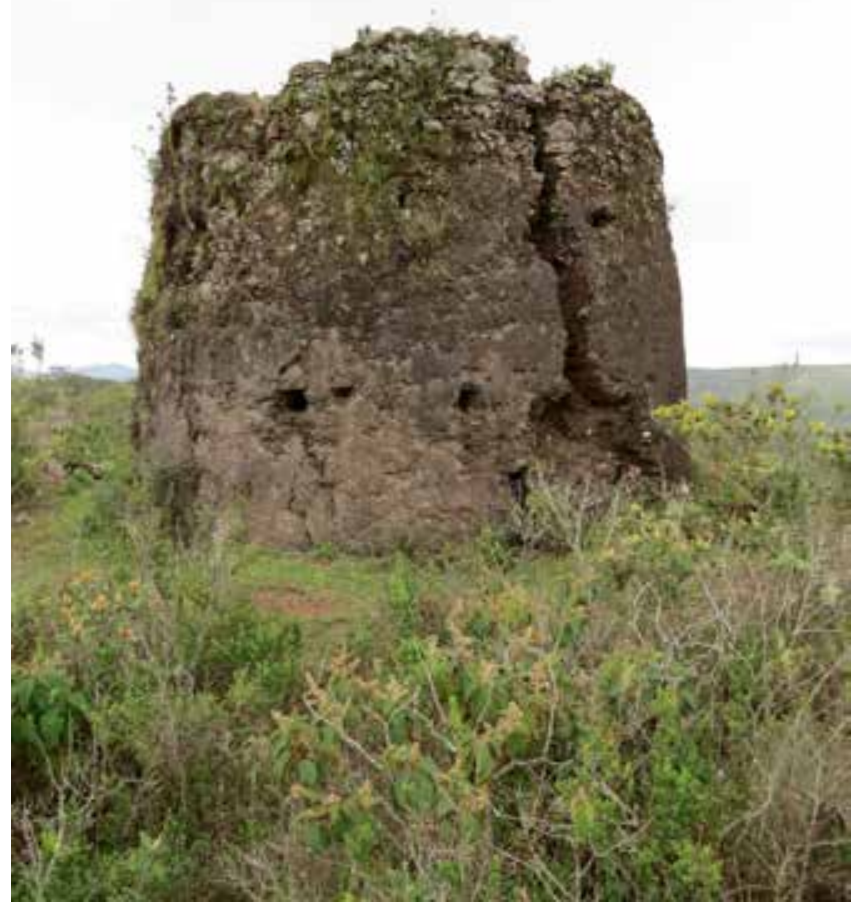

Figura 1 - Ruínas do moinho de vento no topo do Morro da Queimada, em Ouro Preto, MG, 2013. Fotografia do autor.

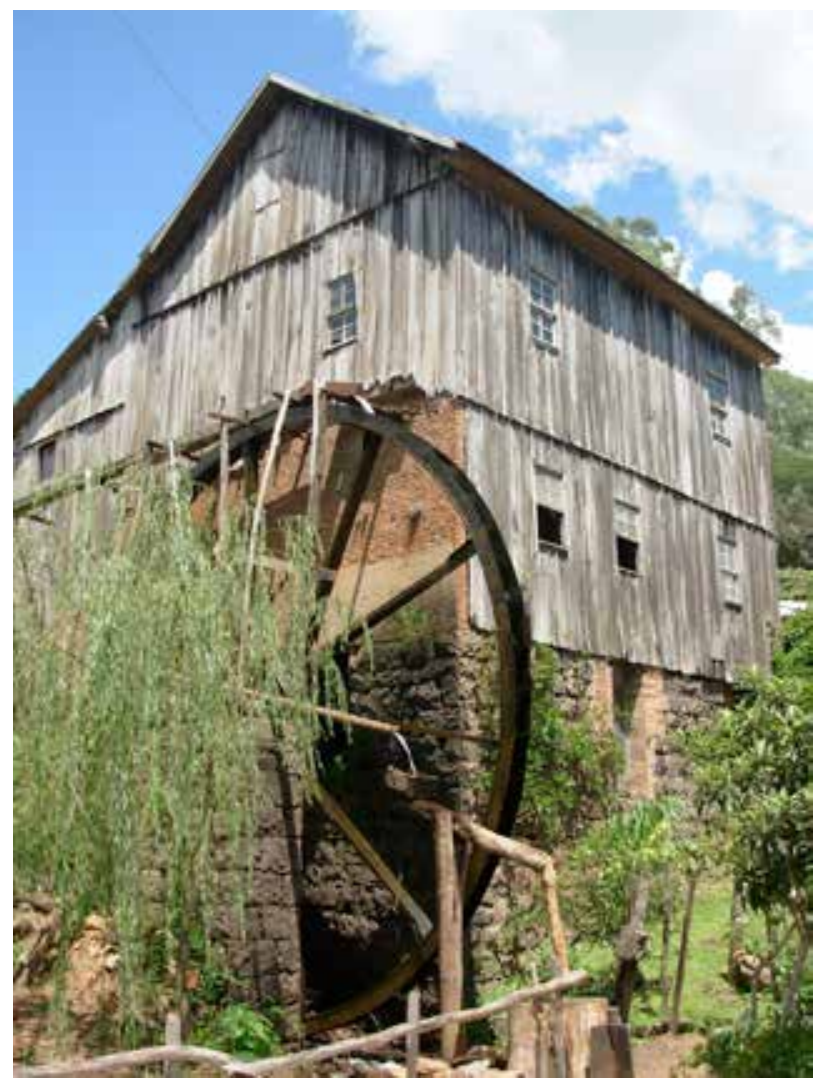

Figura 2 - Azenha de Gramado, RS, construída no início do século XX por imigrantes italianos. Notar o pequeno monjolo associado à roda hidráulica. Fotografia do autor, 2007.

Annals of Museu Paulista. v. 23. n.1. Jan.-Jun. 2015. 
6. No norte da Itália, o milho já exercia função alimentar importante desde a segunda metade do séc. XVI. E desde o século XVIII começou a ser usado de forma mais ampliada pelos camponeses do restante do país. Ver Jean-Louis Flandrin; Massimo Montanari (1998, 539-540).

7. Uma propriedade bem antiga (chegou a contar com uma sede bandeirista), a fazenda foi quase totalmente reconstruída entre as décadas de 1890 e 1920 período em que se construiu, certamente obra de um carpinteiro italiano, a azenha, que ainda hoje mantém-se íntegra.

8. O próprio termo "azenha" sempre foi pouco usual no Brasil colonial, e mesmo quando utilizado, não raro visava descrever outros tipos de maquinismo, como os empregados nos engenhos de açúcar nordestinos. Não é outro o caso do relato do padre jesuíta Jacome Monteiro, que se faz valer do termo "azenha" para descrever as novas moendas empregadas nos engenhos da Bahia. Cf. Serafim Leite (2000, p. 404). já habituados ao consumo do milho e à raridade da triticultura no estado no período 6 . Explica-se, desse modo, a disseminação de pequenas azenhas em diversos núcleos coloniais, como a que existiv em Gavião Peixoto, então parte do município de Araraquara (Figura 3).

Mais raras foram as azenhas nas fazendas maiores, já que, por essa época, o desflorestamento e a facilidade de acesso às rodas d'água de ferro inglesas dispensavam os fazendeiros mais prósperos de contratar a obra de carpintaria. Ainda assim, encontra-se hoje um exemplar interessantíssimo em ltu, na fazenda da Serra, localizada na estrada para Cabreúva (Figura 4) ${ }^{7}$. As muitas famílias italianas ali estabelecidas parecem ter tornado a região próxima a ltu pródiga em pequenas azenhas - como indica outro exemplar em Cabreúva, que chegou a ser inventariado pelo Condephaat em fins dos anos 1970 (Figura 5).

Da excentricidade dos moinhos eólicos e do surgimento tardio de azenhas no Brasil, resulta a impossibilidade da moagem colonial ter sido baseada nesses tipos de maquinismo ${ }^{8}$. Na verdade, azenhas e moinhos eólicos eram máquinas cuja sofisticação e boa potência sempre foram associadas a moagens de maiores proporções. Uma das principais características dos moinhos brasileiros foi a de ter sempre operado em uma escala muito reduzida quando comparada com a moagem europeia. E é justamente o predomínio da pequena moagem que explica a enorme estabilidade das soluções e agenciamentos técnicos que caracterizaram os moinhos hidráulicos brasileiros.

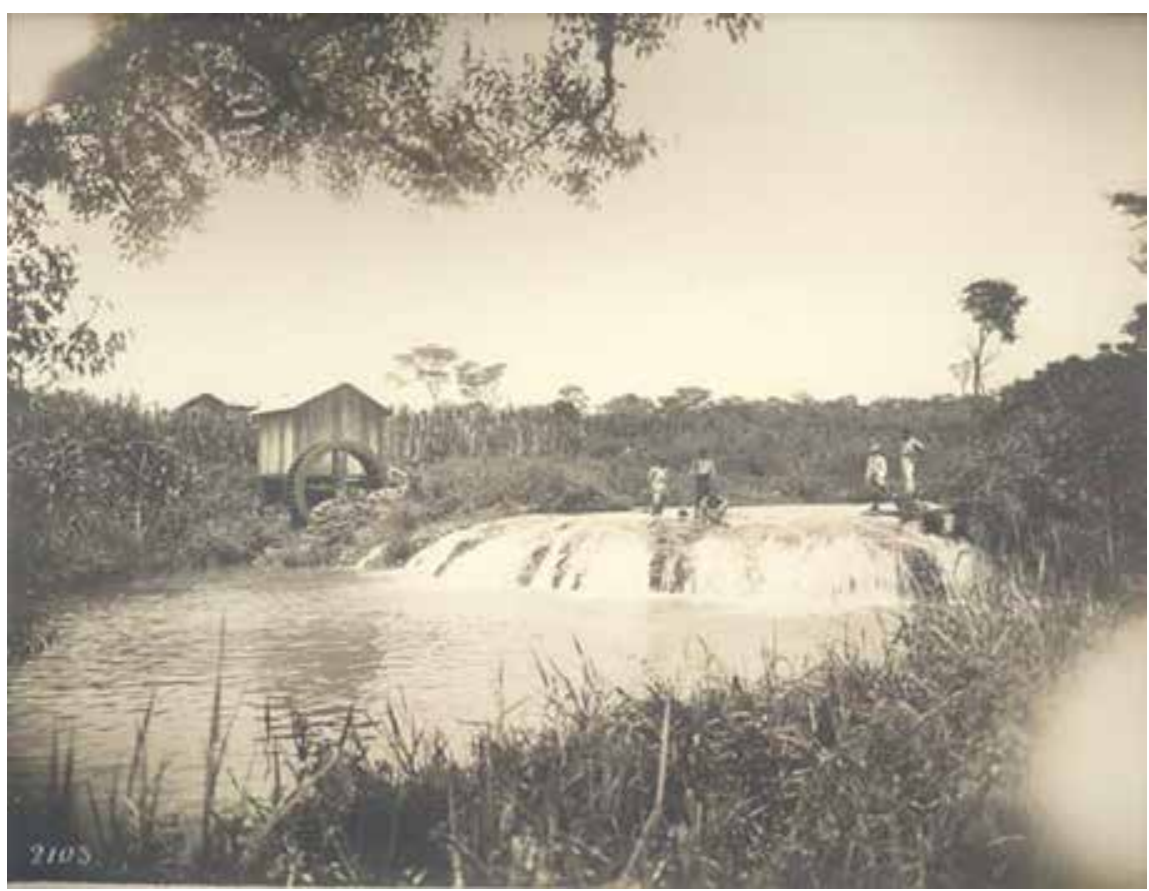

Figura 3 - Azenha construída no núcleo colonial Gavião Peixoto, em Ibitinga, SP. Fotografia de Guilherme Gaensly, 1906, fotografia sobre papel, 22×28cm, acervo do Centro de Memória da Unicamp - Coleção Secretaria de Agricultura, Comércio e Obras Públicas do Estado de São Paulo. 
Desse modo, durante a maior parte de sua história, o Brasil só conheceu os moinhos horizontais, também chamados de moinhos de rodízio. Tratava-se, quase sempre, de pequenos moinhos, cuja simplicidade se demonstra pelo esquema presente na (Figura 6). São moinhos de rodízio também os únicos descritos pelos viajantes estrangeiros do século XIX. Não se somam muitos testemunhos deles algo facilmente compreensível, dado o abismo existente entre a moagem brasileira e a europeia. Exemplar, nesse sentido, é o relato de John Luccock, viajante inglês que percorreu o Rio de Janeiro e Minas Gerais em 1817, sobre o moinho existente na fazenda do Padre Correia, hoje proximidades de Petrópolis:

Ali havia também um moinho, tal como os que são muito comuns no interior do Brasil, mas talvez peculiares a esse país. Compõe-se de uma roda horizontal, de diâmetro aproximado de quatro a cinco pés; em redor da circunferência, acha-se colocado, no plano da roda, um certo número de pás, que semelham uma metade de coco cortado longitudinalmente. A água é encaminhada por uma calha de madeira a que possa bater com força de encontro às pás, imprimindo rotação ao moinho. $\bigcirc$ eixo passa através do soalho de um pequenino edifício, onde impele somente um par de mós?.

A errônea suposição de Luccock sobre a peculiaridade dos moinhos de rodízio brasileiros é plenamente compreensível. Como europeu, vindo de um continente que explorara ao máximo o aproveitamento da energia hidráulica por rodas d'água de madeira, os modestos rodízios brasileiros deveriam atrai-lo também

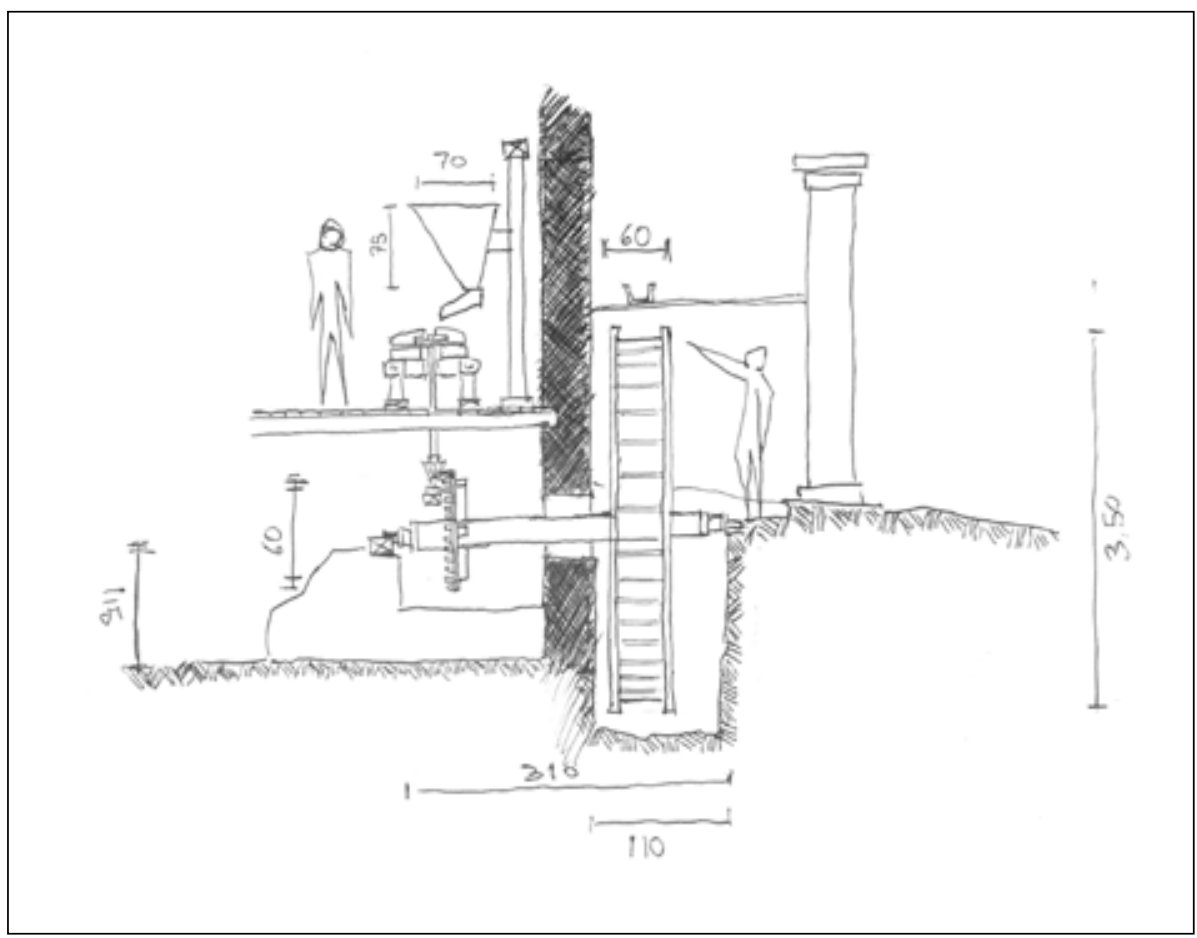

Figura 4 - Azenha existente em fazenda em antiga estrada de ltu para Cabreúva, SP. Desenho do autor.
9. Cf. John Luccock ([s.d.], p. 252). 


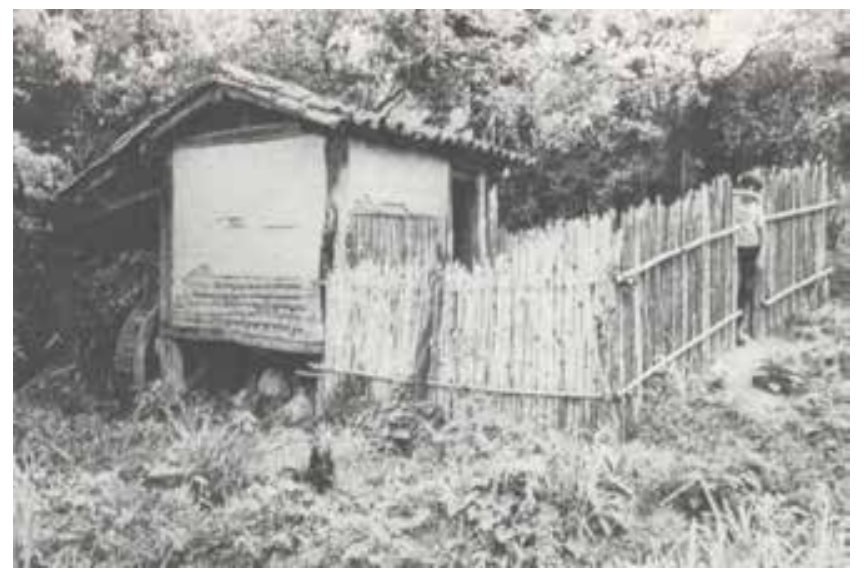

Figura 5 - Pequena azenha que existiu em Cabreúva, SP, até a década de 1990. Fotografia de Eduardo Castanho. Fonte: Júlio Roberto Katinsky (1985).

Figura 6 - Esquema de moinho de rodízio com indicação da terminologia mais utilizada no Sudeste. Desenho do autor.

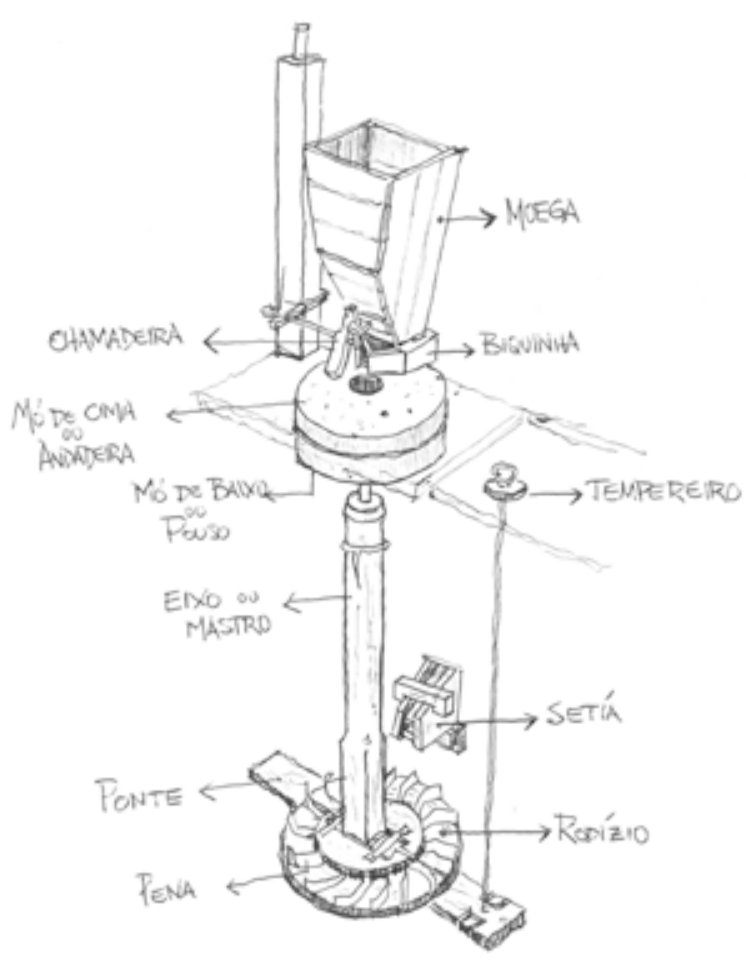

10. Em outros casos de descrições de técnicas aqui adotadas, foi a atração pelo pitoresco que também deu a tônica dos registros dos viajantes. Não por outro motivo, o exótico monjolo pareceu muito mais assíduo nessa literatura do que outros equipamentos tão ou mais comuns que o maquinismo de origem oriental.

11. Cf. John Luccock ([s.d.], p. 252). pelo seu ar canhestro ${ }^{10}$. Ao olhar pitoresco, contudo, não escapou a pertinência do moinho horizontal ao contexto brasileiro. É o próprio Luccock, ainda comentando sobre o moinho por ele encontrado na Serra dos Órgãos, que observa que, apesar de possuir "potência muito restrita (...) recomenda-se nas regiões montanhosas por poder aplicar-se a quase que qualquer posição, pela simplicidade de sua estrutura e pequeno custo de sua instalação" 1 .

A observação de Luccock sobre a relação entre pequenos moinhos e relevos acidentados nos fornece uma das chaves para compreendermos as causas da ampla difusão do moinho hidráulico pelo vasto interior brasileiro. Os moinhos de rodízio foram mesmo um equipamento aqui sempre associado a terrenos mais movimentados, cujos cursos d'água encachoeirados poupavam maiores despesas em sua construção. Na realidade, as ótimas condições topográficas características do relevo do interior do país podem ter atenuado as restrições de potência imputadas aos moinhos brasileiros por Luccock. $\bigcirc$ depoimento de John Mawe, outro viajante inglês contemporâneo a Luccok, é esclarecedor nesse sentido: no relato de sua jornada pelas capitanias de São Paulo, Rio de Janeiro e Minas Gerais, encontram-se algumas interessantes descrições de moinhos encontrados. Em Cantagalo, região serrana do Rio de Janeiro, observou que ali o milho era 
moído "por uma roda d'água horizontal, que alcança grande velocidade, movida pela água" 12 . $\bigcirc$ relato de Mawe também oferece aquele que provavelmente é o mais antigo registro pormenorizado de um moinho de rodízio brasileiro (Figura 7). A ilustração, referente ao moinho de Cantagalo, retrata um moinho do mesmo porte que os moinhos descritos por Luccock. Ainda assim, são maquinismos maiores do que os moinhos caipiras conhecidos.

Aos movimentados leitos dos riachos e ribeirões do Planalto Brasileiro, mais do que a qualquer outro fator, deveu-se o tão bom aproveitamento de um maquinismo que no Velho Mundo estava, há muito, obsoleto. Em toda sua área de ocorrência dos moinhos brasileiros, suas implantações sempre procuraram garantir o melhor aproveitamento energético possível dos riachos em que se localizavam. Assim, poupavam aos seus construtores não apenas o custoso trabalho de construir azenhas e engrenagens (nas quais o acesso ao ferro de boa qualidade é imprescindível), mas também obras muito mais onerosas, como barragens e açudes.

Esse princípio, de valor eminentemente prático, não raro produzia quadros de grande beleza cênica. Em Minas Gerais, foram muito comuns os moinhos instalados nas próprias cachoeiras, tendo seus arrimos e fundações estruturados sobre um ou dois rochedos dispostos naturalmente. É esse o caso de um moinho ainda operante atualmente, localizado em São Gonçalo do Rio das Pedras, em Minas Gerais (Figura 8).

Em verdade, o moinho hidráulico difundiu-se justamente pelas regiões do amplo planalto interior brasileiro nas quais as condições morfoclimáticas eram quase ótimas em termos de sua instalação e rendimento. Nesse sentido, nenhuma região brasileira parece ter conhecido associação mais feliz com o velho maquinismo europeu do que o domínio de mares de morros florestados típicos da região sudeste do país ${ }^{13}$. Elevando-se entremeadamente a diversas serras que estruturam o relevo do Planalto Brasileiro, os mares de morros apresentavam
12. Cf. John Mawe (1944. p. 138, itálico nosso).

13. Ver Aziz Nacib Ab'Sáber (2003, p. 16-17).

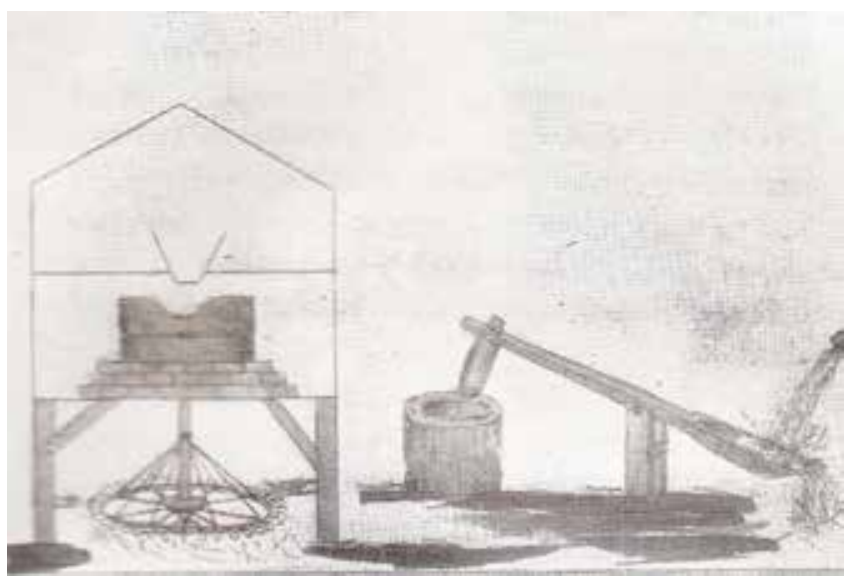

Figura 7 - Esquemas feitos por John Mawe para seu livro Travels in the Interior of Brazil, publicado em 1812, em que são retratados um moinho de rodízio e um monjolo.

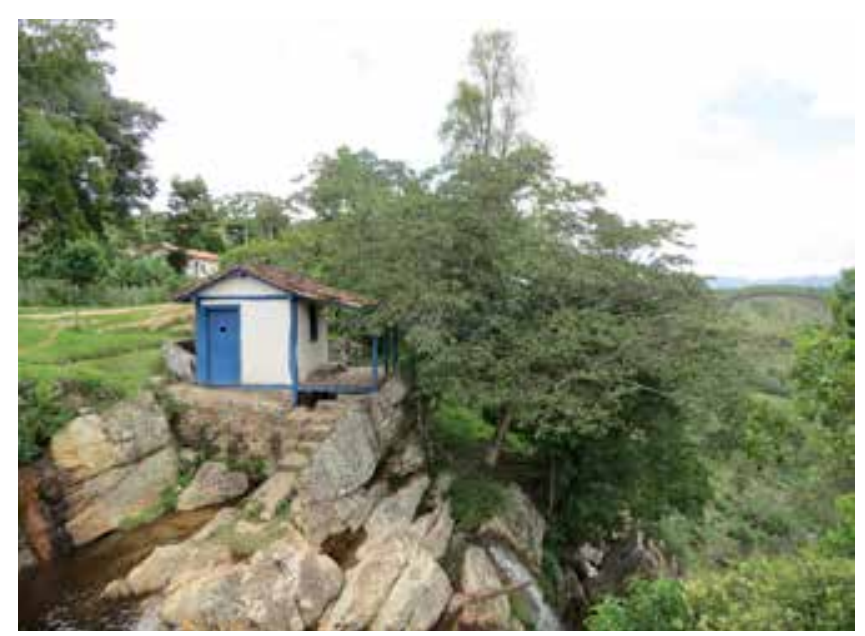

Figura 8 - Moinho construído sobre cachoeira em São Gonçalo do Rio das Pedras, MG. Fotografia do autor, 2013. 
14. Nesse sentido fazem-se válidos também para o interior do Sudeste os argumentos de Gilberto Freyre acerca da maior contribuição dos pequenos riachos e ribeiros na formação das paisagens rurais nordestinas. Diferentemente dos grandes rios de várzea, cujas enchentes e terrenos alagadiços traziam mais estorvos e incômodos, foram os menores cursos d'água muito mais úteis aos estabelecimentos rurais $\mathrm{e}$ urbanos no Brasil. Ver Gilberto Freyre (1967, p. 24). No caso do sudeste do país, a existência de uma rede de drenagem ainda mais generosa aumentava em muito o potencial de aproveitamento dos ribeiros, o que só deve ter começado a rarear quando $o$ desflorestamento passou a comprometer o ciclo hidrológico da região.

15. Ainda que existam outros exemplos de multiplicações de equipamentos idênticos como resposta às pressões produtivas, tais casos sempre procuravam responder a desafios surgidos de limitações provenientes da organização do trabalho humano dentro da cadeia produtiva. Tal é o caso da multiplicação presente nas cozinhas de engenhos de cana, onde a figura do trabalhador artesanal resistiu até a chegada das usinas a vapor. Os moinhos parecem se diferenciar desses casos por não envolver a operação do maquinismo em si, mas sim a sua construção. Ou seja, não seria tanto um caso de organização do trabalho humano dentro da cadeia produtiva, mas sim de busca de outras soluções técnicas. Ver Ruy Gama (1978, p. 80 e 165).

16. Exemplos de até três pequenos moinhos assentados em uma mesma levada chegavam a ser excelentes terrenos para moinhos, dotados de abruptas variações na declividade. Além disso, os altos índices pluviométricos sempre associados a esse domínio paisagístico garantiam uma boa propulsão obtida a partir de seus riachos e ribeirões ${ }^{14}$

Não se deve, contudo, tomar as condições topográficas aqui encontradas como o único fator determinante para a ampla difusão do moinho hidráulico no Centro-Sul brasileiro. A dispersão do habitat rural também parece ter sido fundamental para o predomínio no Brasil da pequena moagem. A conjunção da baixa densidade populacional no campo e da fraca urbanização foi um fator que nunca permitiu desenvolvimento similar aos que levaram ao surgimento dos grandes moinhos europeus do início da Era Moderna. Dada a baixa demanda demográfica, qualquer moinho bem disposto em queda d'água propícia seria capaz, por mais rústico que fosse, de suprir satisfatoriamente a demanda dos habitantes das redondezas.

Foi a partir dessas condições iniciais que os pequenos moinhos se tornaram tão arraigados em nossas paisagens rurais que, quando o desempenho de um deles já não era mais suficiente, poucos foram os esforços de aperfeiçoamento técnico. Quando se fazia necessário um aumento da oferta, a solução usual sempre foi a da multiplicação da unidade base. Assim, a instalação de dois moinhos de idêntico mecanismo em uma mesma levada d'água não foi um fato raro nas zonas rurais de regiões mais bem drenadas. Se as condições demográficas da ocupação do interior parecem ter sido tão ou mais determinantes na difusão dos moinhos no Brasil, aqui se veria uma solução diretamente resultante das ótimas condições topográficas. Graças às dádivas dos rios de leitos acidentados, respondia-se mais prontamente ao aumento da demanda com a multiplicação dos moinhos do que por meio do aprimoramento de seu mecanismo, já rústico por si só ${ }^{15}$.

Se tal expediente nunca foi desconhecido em Portugal, convém ressaltar os contextos bem diferentes em que a multiplicação se dava nos dois casos. Em Portugal, país em que mesmo as regiões montanhosas apresentam redes de drenagem de pouca monta, a multiplicação de moinhos sempre foi restrita às pequenas aldeias ${ }^{16}$. Ali a baixa demanda e a sazonalidade da moagem nunca justificaram grandes maquinismos, tornando comuns soluções como a de Ribeira de Pena, em que a mesma levada podia tocar até três moinhos, conforme a necessidade (Figura 9). E mesmo assim, conflitos advindos da superexploração dos cursos d'água sempre foram uma constante, principalmente durante o estio.

Já no Brasil, e de maneira muito significativa, foi um recurso comum tanto aos médios sitiantes quanto às grandes fazendas monocultoras. A fazenda Pau d'Alho, em São José do Barreiro, é exemplar nesse caso: ali uma mesma levada de água movia a robusta bateria de pilões, que beneficiava os grãos de café, e as pedras de dois moinhos de fubá, que garantiam a alimentação da escravaria local (Figura 10). 


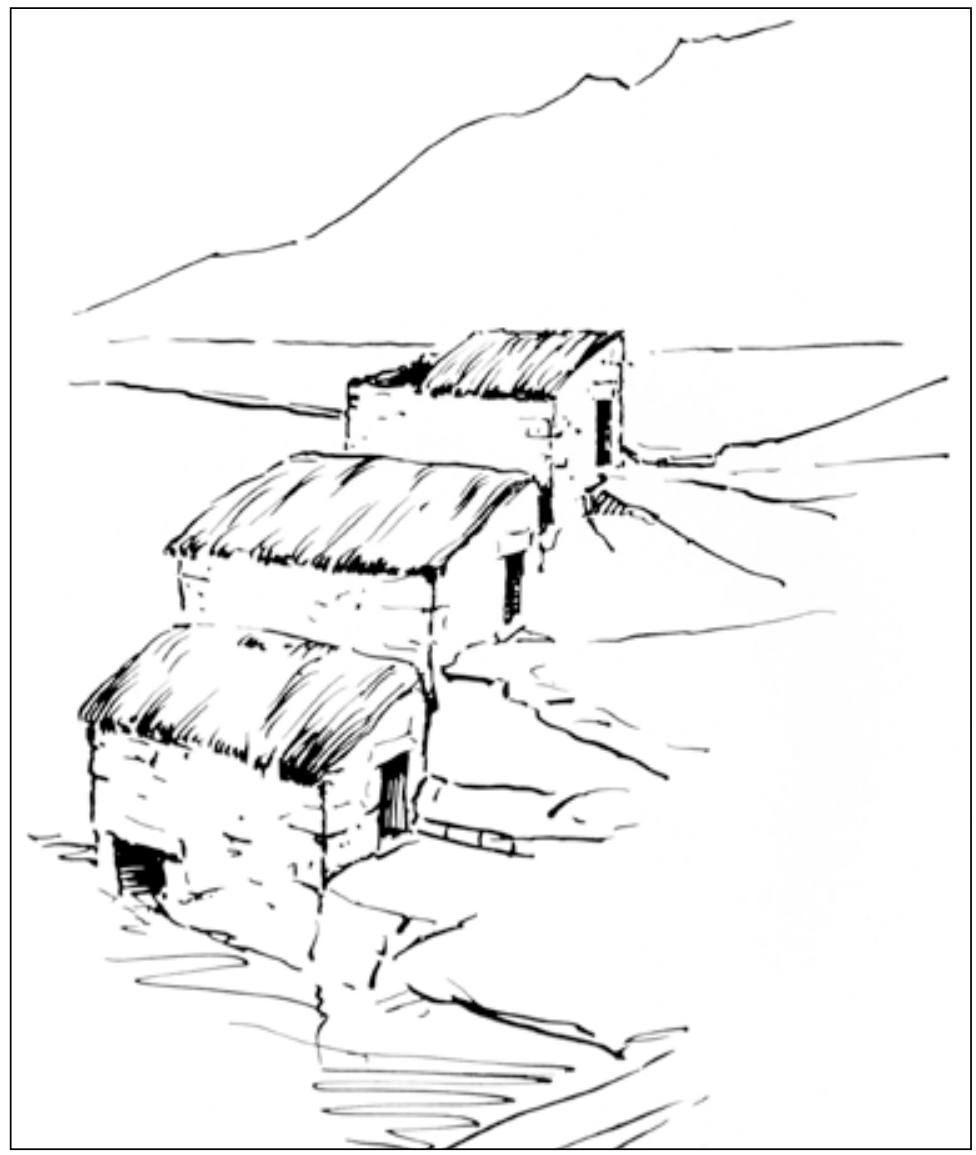

encontrados em Portugal. Ver Ernesto Veiga de Oliveira; Fernando Galhano e Benjamim Pereira (1983, p. 145) e Figura 115.

Figura 9 - Multiplicação de moinhos horizontais em uma mesma levada. Fernando Galhano. Ribeira de Pena, nanquim sobre papel, [s.d.]. Fonte: Fernando Galhano (1985)

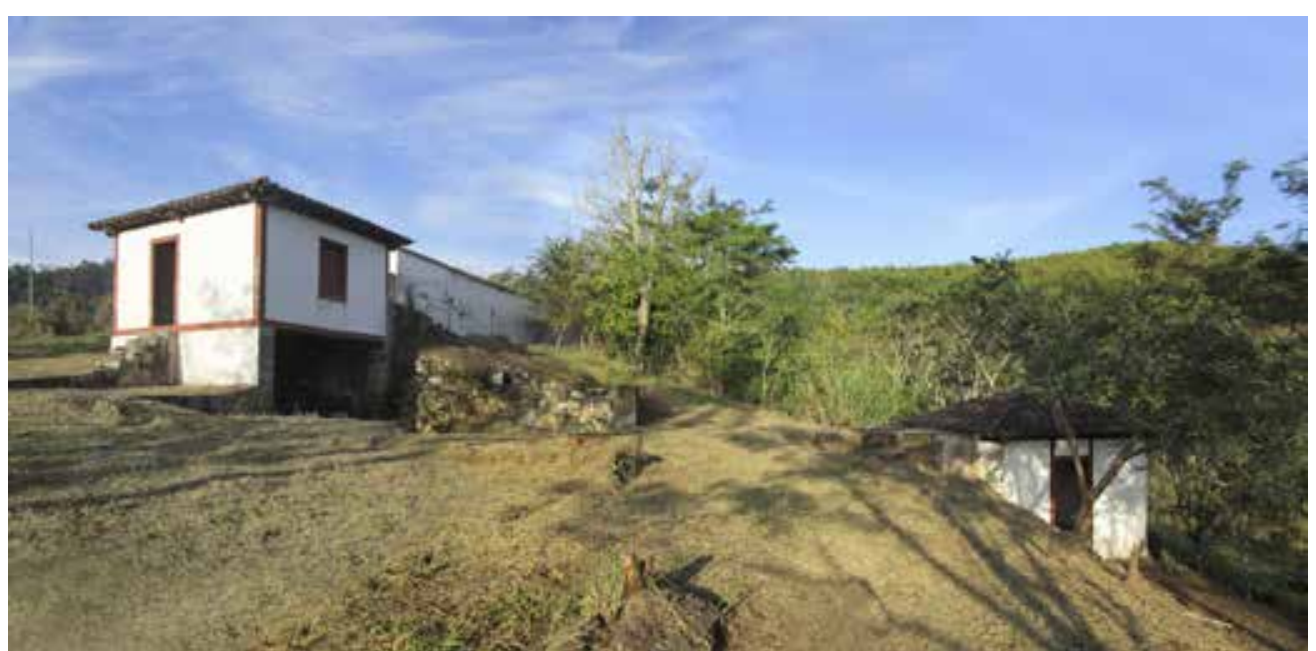

Figura 10 - Moinhos de rodízio da fazenda Pau d'Alho, em São José do Barreiro, SP. Fotografia de Victor Hugo Mori, 2014. 
17. Ver Sérgio Buarque de Holanda (1957, p. 221-222).

18. "Complexo do milho" é a expressão mais comum para designar as demais plantas consorciadas ao cereal americano nas roças, como os feijões e as abóboras, que além de diversificar a dieta alimentar também cumprem a importante função de repor nitrogênio e azoto nos solos agrícolas. A expressão abrange também a criação de pequenos animais domésticos cuja alimentação o milho participa com mais peso, como a das aves domésticas e do gado suíno.

19. Ver Sérgio Buarque de Holanda (1957, p. 225). Ao dar importância à adaptação de técnicas adventícias ao meio colonial, as teses de Holanda explicavam, muito mais plausivelmente, as circunstâncias da introdução do monjolo asiático no Brasil - fato que ainda guardava aura de lenda na historiografia brasileira do período. Ver Sérgio Buarque de Holanda (1957, p. 226244).

20. A distinção entre os dois padrões alimentares é bem antiga nos estudos brasileiros e operaram sempre como fatores diferenciadores entre duas grandes macrorregiões. No Norte e Nordeste, além de toda a costa marítima do país, a mandioca preponderava na alimentação de toda a população. Já no interior dos estados do Sudeste, CentroOeste e Sul do país, os habitantes teriam no milho seu esteio alimenta. Ver Josué de Castro (1966, 136152).

21. O estudo da historiadora Laura de Mello e Souza é um belo exemplo de como a dinâmica da vida em trânsito era estruturada em ritmos e técnicas advindas do intercâmbio com os indígenas. Ver Laura de Mello e Souza (1997).
Os moinhos de fubá e os sistemas agrários brasileiros

Vistos os principais tipos de moinhos outrora presentes no Brasil e a plena adequação dos pequenos moinhos horizontais às paisagens e à evolução demográfica do país, resta verificar como os usos a que foram destinados contribuíram para sua difusão. E a resposta, à primeira vista, é bem simples, e há muito conhecida: foi a importância que o cultivo do milho adquiriu no interior do país que levou os colonos a adaptar as técnicas da moagem europeia para 0 cereal nativo da América, vulgarizando os moinhos conforme novas paragens iam sendo povoadas. Essa tese, por mais que esteja correta em linhas gerais, oculta pormenores de grande interesse à história das técnicas no Brasil.

De acordo com a famosa interpretação de Sérgio Buarque de Holanda, não só as técnicas de beneficiamento, mas toda própria agricultura baseada no milho devia sua preponderância, em São Paulo, à influência de um tipo social muito bem definido: o mameluco ${ }^{17}$. O "complexo do milho" teria emergido como resultado de maiores pressões comerciais sobre a cultura andeja e fronteiriça própria dos mamelucos paulistas ${ }^{18}$. Os moinhos hidráulicos de São Paulo, sem uso desde que participaram de uma malograda experiência de integrar o trigo à dieta alimentar paulistana durante século XVII, teriam sido então adaptados para a moagem do milho ${ }^{19}$.

Grande parte do sucesso da tese da "civilização do milho" buarqueana, entre historiadores e cientistas sociais, reside no fato de ela ter postulado, pela primeira vez, razões históricas para a existência de regimes alimentares marcadamente distintos no Brasil: um baseado no milho e outro na mandioca ${ }^{20}$. Por meio de argumentos simples e elegantes, fortemente calcados nos distintos contextos sociais, o eminente historiador mostrava o quão simplistas eram as explicações que atribuíam causas eminentemente climáticas para a prevalência do "complexo do milho" apenas no interior do país.

Há algo inquietante, contudo, quando se examina a interpretação de Holanda sob as óticas da história da técnica e, principalmente, sob a ótica da história da agricultura. E essa inquietação está na implausibilidade de todo um sistema agrário (pois o "complexo do milho", bem como o da mandioca, não são senão sistemas agrários) encontrar sua justificação na cultura alimentar de uma camada um tanto circunscrita da população. Dada a alta complexidade de um sistema agrário, qualquer que seja seu nível de desenvolvimento técnico, seria um tanto improvável que sua vigência por séculos em uma região tão vasta fosse devido à adaptabilidade de sua planta-base ao cotidiano de uma pequena, ainda que destacada, parcela de sua população ${ }^{21}$. Por mais notórios que tenham sido os sertanistas, monçoeiros, peões e tropeiros, que faziam dos caminhos sua rotina, é difícil crer que tivessem uma influência tão grande em questões tão complexas. Ainda mais em um território em que os transportes foram sempre um obstáculo, e as viagens, verdadeiras provações. Não é, portanto, em um tipo de homem que se deve procurar as respostas, mas em um modo específico de organizar a produção agrária. 
Em estudos hoje clássicos, Maria Yedda Linhares defendia que somente um conhecimento mais aprofundado da história da agricultura brasileira permitiria avanços historiográficos para além dos modelos econômicos iniciais sobre o passado colonial. Como argumentava a historiadora, estavam, então, patentes as limitações dessas abordagens no estudo da produção agrária existente na colônia, malgrado os tratamentos diferenciados propostos por seus defensores. E, de maneira generalizante, pode-se dizer que sua principal falta foi sempre ter postulado o predomínio das plantations escravistas exportadoras. Dentro do paradigma da plantation, única forma possível de se organizar a produção econômica efetiva, pouco restaria às regiões onde sua implantação não fora possível a não ser a marginalização econômica que delongava ali os ares de sertão ${ }^{22}$.

Tão profícua foi a contribuição das críticas de Linhares e seus colegas que, seguindo a direção por eles proposta, os estudos sobre o passado colonial brasileiro vêm obtendo alguns de seus mais interessantes resultados. Em particular, cabe aqui apontar o quanto a interpretação dicotômica entre plantations colonialistas e roças de subsistência primitivas vem dando lugar à emergência de cenários agrários mais diversificados. Como resultado, um "mosaico de formas não capitalistas de produção" - na feliz expressão de João Luís Fragoso - vem emergindo com um potencial muito maior para elucidar as particularidades regionais da formação histórica brasileira ${ }^{23}$. Mesmo a noção de "complexos" baseados em um cultivo principal e extensivos à amplas zonas já não dá conta da diversidade agrária que existiu no Brasil desde a colônia.

Nesse contexto, a crítica à interpretação de Sérgio Buarque de Holanda não é de modo algum gratuita - muito menos inédita. E o interesse que ela desperta neste artigo reside na função que os moinhos hidráulicos podem exercer como sinalizador eficiente de alguns tipos de sistemas agrários comuns durante a ocupação do interior do Brasil. Como foram os moinhos o equipamento mais sofisticado e polivalente empregado para o beneficiamento do milho, sua presença em um local em determinada época tem muito a dizer acerca de diversos aspectos da organização agrária existente. Permanecem sendo eles um sinal claro da vigência do "complexo do milho" no seu entorno. A dinâmica que mediava essa relação, contudo, deu-se de maneira bem mais complexa do que se costuma considerar. Desse modo, para avançar mais no desvendamento do papel dos moinhos d'água é preciso discriminar os diferentes usos do milho, bem como o peso econômico correspondente a cada um deles.

Onde quer que se localizassem, os moinhos cumpriam um importante papel nas suas paragens, fornecendo o fubá para a confecção de bolos, broas, sopas e o angu - cujo papel sempre foi destacado na alimentação de escravos negros. Da moagem realizada nesses rústicos maquinismos, provinha também a quirera (ou canjiquinha, como é chamada em Minas Gerais), fundamental na criação de porcos, cavalos e aves domésticas. $\bigcirc$ recurso à moagem do milho distingue-se também do seu beneficiamento por meio dos diversos tipos de pilões e monjolos, que serviam exclusivamente para a preparação da farinha de milho
22. Ver Maria Yedda de Linhares e Francisco Carlos Teixeira da Silva (1981, p. 73-170).

23. Cf. João Luis Fragoso (1992, p. 104). 
24. Aqui a distinção entre fubá e farinha de milho é de fundamental importância. Ainda que nem sempre considerada aos olhos de observadores provindo dos meios urbanos, a diferença entre os dois sempre foi gigantesca no meio rural: a farinha é um produto prestigiado, o verdadeiro "pão do milho", ao passo que o fubá nunca gozou de status semelhante - pelo contrário, ao seu uso sempre se associou uma alimentação empobrecida, degradada. Ver Carlos Borges Schmidt (1967, p. 110).

25. A predominância do fubá na alimentação escrava é fato largamente documentado por diversas fontes oitocentistas. Viajantes como Saint-Hilaire, Tschudi, Eschewege registram o fubá como principal recurso alimentar de negros escravos nas províncias do Rio de Janeiro e Minas Gerais. E mesmo Thomas Davatz, o colono alemão da fazenda Ibicaba relata o mesmo papel do fubá entre os primeiros colonos europeus em São Paulo (apud Carlos Borges Schmidt, 1967, p. 106-107). O fubá como esteio alimentar dos escravos foi um fator comum à ocupação de vazios demográficos no Centro-Sul. Nos sertões de Minas Gerais, uma agricultura fortemente baseada no milho conseguiu responder a um boom populacional de escala até então inédita no interior da colônia, sem interferir nas atividades mineradoras; ver José Newton Coelho Meneses (2000, p. 177-180). Ver também Angelo A. Carrara, (2007). O mesmo parece ter se dado na ocupação dos sertões do vale do rio Paraíba do Sul, onde a alimentação baseada no milho cumpria um papel fundamental na administração dos cativos negros; ver Rafael Bivar Marquese (2010, 203-231). propriamente dita ${ }^{24}$. Se a farinha de milho gozava de prestígio, o fubá foi sempre a base da alimentação dos escravos, principalmente quando não se podia contar com bons aportes de gêneros cultivados em tempo livre ${ }^{25}$.

O fubá era, sobretudo, parte importante da ração de criações de animais, enfim para o qual nunca se empregou a farinha de milho ${ }^{26}$. Aqui esbarramos em uma característica do complexo do milho poucas vezes explorada a fundo - cujas consequências podem ter sido nada pequenas e de impressionante duração: o entrelaçamento profundo entre as populações humanas e seus animais de criação. Foi a prodigiosa fecundidade do milho que permitiu alimentar relativamente densas populações de homens e seus rebanhos, provendo as paragens interiores tanto de diversidade alimentar como de melhores meios de inserção nos circuitos mercantis. Desse modo, seria não somente seu uso na alimentação humana, mas o sólido consórcio entre homens e animais possibilitado pelo milho que teria determinado sua preponderância na agricultura do Centro-Sul do Brasil.

Na verdade, o milho foi de vital importância para que os sistemas agrários do centro-sul nunca tenham cindido completamente a lavoura da pecuária. O divórcio entre agricultura e criação de gado há muito é considerado como mais um dos desatinos técnicos do atraso colonial ${ }^{27}$. E foi uma solução que marcou de maneira profunda os sistemas agrários das regiões açucareiras coloniais mais antigas. As maiores regiões produtoras de açúcar do litoral chegaram mesmo a desassociar completamente os canaviais da lavoura de gêneros alimentícios, ganhando mesmo ares de regra. E o fato de que mesmo os efêmeros engenhos quinhentistas de Santos e São Vicente foram capazes de fazer do seu abastecimento de carne e couro uma das únicas alternativas econômicas aos campos de Piratininga demonstra a força dessa dinâmica econômica ${ }^{28}$.

É interessante observar, contudo, como - a partir da estruturação de sistemas agrários baseados no milho no interior da colônia - essa tripartição pode ter perdido força em algumas áreas. Nesse sentido, é útil comparar o quanto formas de abastecimento regionais foram se diferenciando ao longo do tempo. As provisões de gêneros agrícolas e da pecuária das zonas açucareiras do Nordeste e da costa do Atlântico Sul eram bem similares inicialmente. No entanto, é patente - quanto começaram a se distanciar na medida em que uma agropecuária baseada no milho ganhava força na hinterland da costa do Sudeste. A partir do século XVIII, a intensa tripartição entre zona canavieira, zona de agricultura de abastecimento e zona de currais parece não mais ter vigorado nas capitanias ao sul - ou o fez de maneira muito mais atenuada ${ }^{29}$. E tal desaparecimento intriga ainda mais quando se considera que a tripartição foi uma das molas do desenvolvimento regional nos séculos anteriores. Ao longo de quase todo o século XVII, os engenhos existentes ao redor baía de Guanabara contavam com o gado bovino dos campos de Santa Cruz, onde se localizavam os extensos currais da Companhia de Jesus. E boa parte dos gêneros consumidos na cidade do Rio de Janeiro provinha também das fazendas do planalto paulista ${ }^{30}$. 
Não se trata de postular protagonismos desmedidos aos novos regimes agrários nesse processo. Ainda mais porque essa mudança acontece no mesmo período em que uma maior diversificação da economia colonial era um fato notável em toda a região do Centro-Su| ${ }^{31}$. Mas como são ainda poucas as pesquisas sobre as formas produtivas que permitiram o progressivo incremento da agricultura colonial, a influência de novos rearranjos técnicos pode ter sido maior do que se pensava. Nesse caso, faz-se útil observar que nada similar à cisão agrária entre plantation, abastecimento e pecuária surgiu nos Campos de Goitacazes ou na região conhecida como o Primeiro Oeste paulista - zonas açucareiras importantes no século XIX32.

Em uma situação quase totalmente oposta, estaria o Nordeste brasileiro, onde a tripartição produtiva perdurou na agricultura até a transição para uma economia urbanizada ${ }^{33}$. Sintomaticamente, nas regiões açucareiras da Zona da Mata, onde concentrava-se o maior contingente populacional da região, o milho sempre teve um papel reduzido nas lavouras e na mesa de seus habitantes ${ }^{34}$. Uma característica não explicada inteiramente pela preferência da mandioca como o esteio alimentar da população do litoral nordestino. A ausência de grandes milharais, por exemplo, foi fato sempre ressentido nas zonas pecuarista do Vale do Rio São Francisco e do alto sertão. Como são regiões áridas e de solos pobres, ambas tinham ainda nas baixas densidades populacionais - típicas da pecuária extensiva - um entrave a mais para o incremento da lavoura. E as consequências desse arranjo nunca foram poucas nem pequenas. Sem poderem contar com uma complementação alimentar, tanto o gado como os homens ficavam mais vulneráveis às grandes secas que, periodicamente, abatiam-se sobre a região - e que nos anos mais terríveis viram zonas inteiras sucumbir à fome e ao despovoamento.

A força ou frouxidão dos laços entre lavoura e pecuária repercutiu até mesmo na diferenciação das espécies de plantas e animais adotadas em uma região ou em outra. E em um arrolamento das espécies mais comuns aos sistemas agrários do Nordeste e do Centro-Sul encontra-se, mesmo que implicitamente, a marca da presença (ou da ausência) do milho.

A pecuária nordestina apresentava algumas peculiaridades esclarecedoras a esse respeito. No Vale do Rio São Francisco, por exemplo, dominava o gado bovino, que era apto, mesmo que a duras penas, a manter-se apenas com as pastagens disponíveis na região e com o sal que conseguia encontrar nos "lambedouros" 35 . Notável é a ausência ali do gado suíno, o qual precisa ser mantido com rações que, em terras brasileiras, sempre tiveram no milho o seu principal ingrediente ${ }^{36}$. Do mesmo modo, mas de forma atenuada, rareavam grandes criações de aves como galinhas e perus, também grandes consumidores de grãos de milho.

Em verdade, na ausência de milharais encontram-se fortes razões que ajudam a explicar a notoriedade dos caprinos na pecuária nordestina. Animais de admirável resistência, foram as cabras e bodes uma das grandes distinções da pecuária nordestina em relação à do restante do Brasil. Seu primado, contudo, não se dava sem alguns reveladores transtornos, como a necessidade de robustas cercas separando as roças e hortas da voracidade de cabras e bodes esfomeados ${ }^{37}$.
26. Na verdade, desde LeviStrauss, há boas razões para crermos que o prestígio da farinha de milho se deva mais ao distanciamento entre homens e animais, conferido pelo seu consumo, do que às suas qualidades sensíveis.

27. Caio Prado Jr. foi um dos primeiros a considerar toda a extensão dos efeitos dessa cisão na formação econômica brasileira. E apontava alguns casos de maior interesse na pecuária bovina no trecho mineiro da bacia do Rio Grande, cuja superioridade técnica foi alicerçada justamente pelo seu consórcio com a lavoura ali praticada. Ver Caio Prado Jr. (1942, p. 182 e ss).

28. Ver John Monteiro (1994. p. 101-102).

29. É forçoso reconhecer que a produção de açúcar da Guanabara, onde se concentrava o maior número de engenhos da costa do Sudeste, já apresentava sinais de esgotamento quando uma economia rural sólida se estabeleceu no seu interior, cujo povoamento só se iniciou mesmo a partir do século XVIII. Ver Marcos Guimarães Sanches (1990, p. 12-22).

30. Ver Maurício de Abreu (2010, vl. I, p. 280) e (vol. II, p. 64-65).

31. Ver Marcos Guimarães Sanches (1990, p. 22-24).

32. Itu parece ter conhecido, na realidade, uma forma de especialização regional presente no termo da vila. Os bairros rurais de Pirahy e Anhambu concentravam as grandes fazendas de açúcar, enquanto na região da outra margem do Tietê, no Apotrebu, concentravam propriedades menores cuja produção consistia basicamente de milho, feijão, amendoim e outros gêneros alimentícios. Ver 
Jaelson Bitran Trindade (1980, p. 114-121.). Ainda assim, trata-se de uma especialização em escala muito reduzida, que não condiz com o grande volume de açúcar que distinguiu a produção da região.

33. Na Bahia, por exemplo, os engenhos predominaram por todo o Recôncavo. O abastecimento dessa área dependia, em grande parte, de remessas de mandioca e lenha de vilas nas capitanias de Porto Seguro e Ilhéus. Sem falar que a Bahia foi um ponto de penetração da pecuária pelo vale do rio São Francisco mais importante do que Pernambuco. Ver Stuart B. Schwartz (1988, p. 86-89).

34. Ver Josué de Castro (1966, 142-145).

35. Ainda que os meses de seca castigassem muito o rebanho, obrigando a longas caminhadas atrás de um olho d'água ou de alimento, somente nas estiagens mais drásticas as perdas eram anormais. Ver Jozé Norberto Macedo (1953, p. 4).

36. O sertão chegou mesmo a conhecer uma raça "crioula", rústica e apequenada. Seus rebanhos, contudo, nunca foram significativos, justamente por ser dificultoso dispor de alimentos para a engorda de muitos porcos ao mesmo tempo. Há alguns dados bem mais recentes, mas que espelhariam dinâmicas antigas -referentes às ocasiões em que as vazantes de início de inverno destruíam as plantações de milho, quando o preço do porco subia de maneira singular. Ver Jozé Norberto Macedo (1952, p. 45).

37. Surgidas em grande parte para responder a restrições como essas, as cercas e divisórias do Nordeste conheceram uma
Em uma região em que a cisão entre agricultura e pecuária tornava constante o risco de escassez, animais que, em poucas cabeças, podiam trazer sérios prejuízos às hortas e roças tinham que compensar suas penas de algum modo. E eles o faziam fornecendo leite e carne prescindindo de qualquer outro suplemento nutritivo, nem sal, nem milho ${ }^{38}$.

Muito diferente é o quadro encontrado ao se voltar novamente a atenção para as capitanias ao sul, principalmente nos seus sertões. Nessas paragens, a fecundidade do milho jogou importante papel na conformação de um sistema agrário muito distinto da tripartição nordestina. As colheitas do cereal permitiram não só alimentar os contingentes de mão de obra escravizada, cujo crescimento só cessou no período após 1850, como também sustentaram grandes rebanhos de porcos e as criações de aves domésticas.

Não foi pouca a importância dos rebanhos suínos nessas regiões interiores. Da criação dos porcos, provinha a maior parte da carne consumida no interior do Centro-Sul até o século XIX; em forma de toucinho, a carne de porco era também um item importante do comércio inter-regional; de grande utilidade era também a banha do porco, servindo para cozinhar e também como o principal método de conservar alimentos em qualquer local em que abundassem os suínos. Na realidade, como bem definiu Carlos Borges Schmidt, o mais profundo conhecedor das antigas técnicas rurais caipiras, o porco é o milho que anda: ao se autocarregar, a vara de porcos facilitava a comercialização da safra:

Tal é o caso das regiões distantes dos mercados maiores, e com difíceis meios de comunicações, onde o lavrador, para tornar menos a dificultosa venda da sua safra de milho, transforma-a em carne e toucinho, tangendo-a depois estrada afora. Transformando o milho em produto animal, fica assim poupado o trabalho de descascar, debulhar, pesar, ensacar e transportar: o porco encarrega-se de tudo ${ }^{39}$.

Escrevendo sobre a realidade que conhecera em suas lides como fazendeiro e técnico da Secretaria de Agricultura do governo paulista, Schmidt apresenta um quadro estendível a quase todo o Centro-Sul brasileiro desde épocas bem remotas. Assim, a cena registrada em Paraibuna, no começo do século XX, em que uma grande vara de porcos era conduzida para um mercado (Figura 11 ), repetia uma rotina que foi comum a toda essa grande região desde os primórdios de seu povoamento. Em São Paulo, um dos núcleos irradiadores da ocupação dessa vasta zona, o número de cabeças de porcos parece sempre ter ultrapassado em muito os rebanhos bovinos ${ }^{40}$.

As razões para o predomínio do gado suíno, em grande parte, estavam na abundante disponibilidade de milho para a engorda do rebanho. Tão íntima foi a associação entre milharais e gado suíno que ela não escapou aos olhos dos altos funcionário da administração lusa. Em relatório sobre o estado da agricultura nas vilas litorâneas de São Paulo em fins do século XVIII, um dos governadores da capitania nos fins do século XVIII escreveu que era a ausência do cultivo de milho 


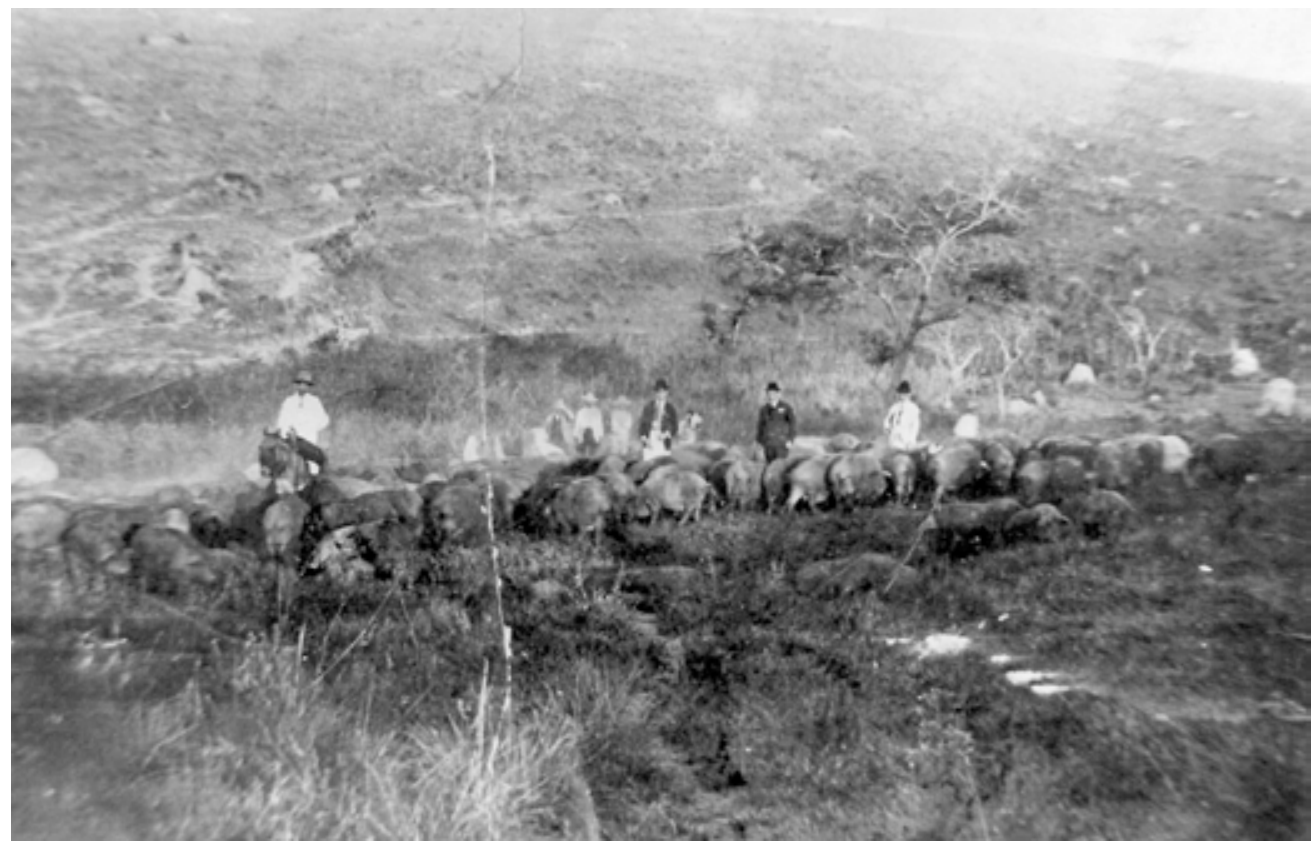

Figura 11 - Transporte de uma vara de porcos da zona rural de Paraibuna, SP, para os mercados de cidades vizinhas. Fotografia de autor desconhecido, ca. 1930, acervo particular.

e feiião entre "os Povos de Serra abaixo" que motivava "nestas paragens a falta de carne de porco" 41 .

Outra diferença notável - e raramente considerada - nas formas de se organizar a produção entre as duas regiões faz-se ver nas distintas técnicas de transporte que acabaram por se impor em cada uma delas. Na região nordestina, por exemplo, nenhum outro meio de transporte terrestre superou, em importância econômica e difusão geográfica, o multimilenar carro de bois. Era por meio desse rústico veículo que se transportavam feixes de cana e cepos de lenha para as casas de engenho, que as caixas de açúcar eram levadas até os portos e que as famílias ricas e remediadas seguiam em suas viagens e passeios ${ }^{42}$. E se a presença do carro de bois fez-se notar em todas as regiões brasileiras, em nenhuma outra sua identificação foi tão forte quanto como no antigo Nordeste açucareiro ${ }^{43}$. Fato que as gravuras topográficas de Frans Post capturam muito bem, ao mostrar o carro de bois, ora nas fainas dos engenhos, ora servindo de transporte à aristocracia local (Figura 12).

Não era apenas a topografia regional, marcada por terrenos baixos e planos, que favorecia a adoção desse meio de transporte. Imprescindíveis aqui eram as reses que vinham do Vale do São Francisco e dos altos sertões. A pecuária sertaneja não só abastecia a marinha de carne e leite, mas também fornecia os bois para as numerosas juntas de carro que transportavam materiais, mercadorias e gentes por toda a região. Nos bois, eram encontrados também importantes "motores vivos" para os trabalhos agrícolas, podendo ser empregados no preparo das terras das fazendas mais diligentes e, sobretudo, nas moendas de almanjarra ${ }^{44}$. variedade de tipos e soluções que não parecem ter encontrado similares no Brasil - fato que mereceu mesmo um interessantíssimo estudo sobre o tema, no qual são elencados mais de vinte tipos de cercas. Ver Manuel Sousa Barros (1985).

38. Ver Mauro Mota, et. al. (1961).

39. Cf. Carlos Borges Schmidt (1946, p. 137).

40. Embora faltem números mais consistentes sobre a criação de porcos durante a colônia, é patente a preponderância do gado suíno nos inventários e testamentos paulistas do século XVII. Os dados, ainda que obtidos em pesquisas cujos focos eram outros, indicam que os suínos sempre responderam pelos maiores volumes de carne arrolados no período. As varas de porcos abundariam sobremaneira que mesmo os maiores criadores de reses - ainda que devessem sua fortuna ao gado bovino - não raro as tinham em menor número do que o de porcos. Ver Milena Fernandes Maranho (2001, 147-148). A pecuária bovina teve sempre um caráter comercial mais acentuado do que a criação de suínos durante o mesmo período, diferença em que o emprego do milho na alimentação dos porcos teve grande influência; sobre o tema ver Rafaela Basso (2011, p. 142-143).

41. Cf. Antonio Manuel de Mendonça (1961, p. 202).

42. Ver José Alípio Goulart (1959, p. 77-79).

43. Ver Bernardino de Souza (1958, p. 111).

44. Ver Pedro Puntoni (2002, p. 21-22). 
45. O transporte fluvial, contudo, era voltado principalmente para cargas, criando, assim, numerosos pequenos portos particulares ao longo dos rios navegáveis. Ver José Alípio Goulart (1959, p. 2932).

46. A bibliografia sobre as tropas de mulas e a antiga rede viária desenvolvida pelo emprego dos muares sempre foi restrita, não fazendo jus à sua importância para a ocupação do território nacional. Para as tropas de mulas, além dos estudos pioneiros de Aluísio de Almeida e José Alípio Goulart, ver Herbert Samuel Klein (1990, p. 1-25) e Jaelson Bitran Trindade e João Urban (1992). Sobre as estradas coloniais, ver Antonio Gilberto da Costa (2005) e Maria Cristina Wolff de Carvalho (2008).

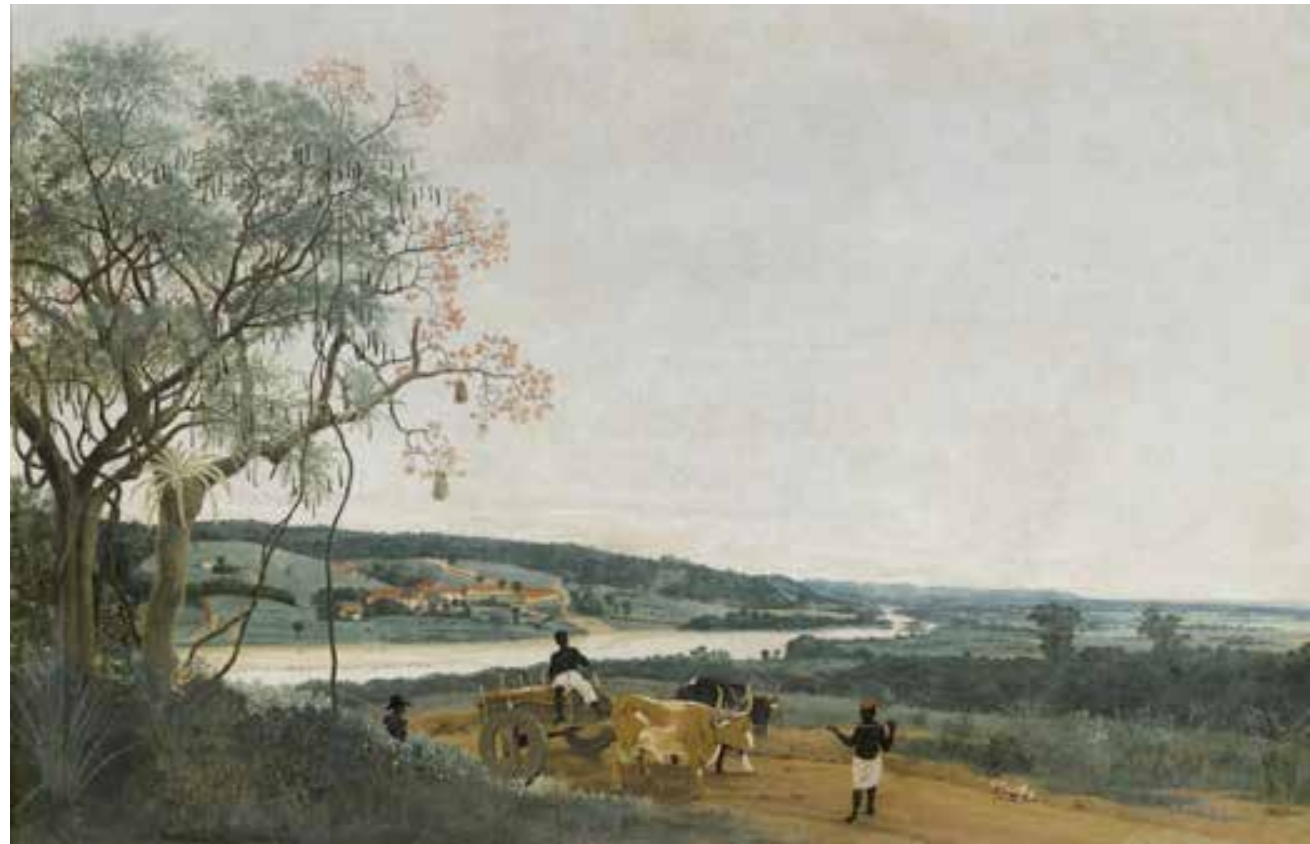

Figura 12 - $\bigcirc$ carro de bois ganha destaque nas paisagens de Frans Post, realçando sua adequação a topografia da zona açucareira do Nordeste. Frans Post. O carro de bois, 1638, óleo sobre tela, $62 \times 95 \mathrm{~cm}$. Acervo do Museu do Louvre.

Em verdade, tão adaptados se fizeram os bois e vacas ao mundo rural nordestino que o único outro meio de transporte importante que ali se conheceu foram as barcaças e canoas - técnicas também típicas de regiões de planícies ${ }^{45}$.

Nesse âmbito, em tudo diferem as soluções dominantes nas capitanias ao Sul. Nessa região dominada por planaltos e serras, o transporte fluvial não se fazia sem muitas dificuldades, e o carro de bois sempre teve um préstimo reduzido. As técnicas de transporte, portanto, teriam que ser outras. E é interessante ver o quanto a solução prevalecente - o uso maciço de tropas de mulas cargueiras - acabou por ser mais um fator da solidariedade entre lavoura e pecuária no Centro-Sul.

Fenômeno típico de zonas montanhosas, as tropas de muares eram, em verdade, o único meio disponível na época da colonização para vencer as dificuldades impostas pela acidentada topografia do interior do continente ${ }^{46}$. Em realidade, a presença de diversas serras e uma real cordilheira la serra do Espinhaço), aliada aos altos índices pluviométricos, fazia da hinterland dos portos do Sudeste uma das zonas tropicais mais inóspitas para a circulação de grandes comboios, como retratam bem mais de uma antiga ilustração (Figura 13). A conquista desse vasto espaço, portanto, muito deve à incrível resistência e obstinação desses animais, capazes de suportar pesadas cargas sob condições tão penosas que fariam um bom cavalo de marcha perecer em poucos dias. E o aditivo do qual dependia toda essa intensa circulação de gentes e riquezas era, basicamente, o milho administrado às mulas a cada parada da tropa. 
Um documento um tanto tardio, de meados do século XIX, estabelece com clareza a dependência estreita entre a circulação colonial e a disponibilidade de altas quantidades de milho cultivado:

O cadastro do preço do transporte entre nós é o custo do milho; tem aquelle sempre sido regulado por este, e acompanhado todas as suas phases e oscillações.

No interior, como se sabe, todo o transporte é feito ás costas de bestas, por meio das tropas; e o burro, em compensação de tantos trabalhos que pacientemente presta á agricultura, exige apenas uma retribuição diaria, um pouco de milho, nutrição a que está affeito, e que é indispensável para manutenção de suas forças e conservação de sua saúde, que sobremodo soffrem com a falta do uso desse grão; o emmagrecimento, a peste e todas as enfermidades próprias das bestas muares são as conseqüências immediatas de sua privação. Por isso, por elevado que seja o seu peso, o milho há de ser fornecido aos animaes ${ }^{47}$.

Nesse texto, escrito em 1855 por Luis Peixoto de Lacerda Verneck, filho do Barão de Paty de Alferes e rico cafeicultor do Rio de Janeiro, fica clara a importância que o milho tinha para todo o sistema de transporte brasileiro. Era a gramínea que garantia o suplemento alimentar necessário às dezenas de milhares de mulas que transitavam pelos caminhos do interior entre o final do século XVIII e meados do séc. $X \mid X^{48}$.

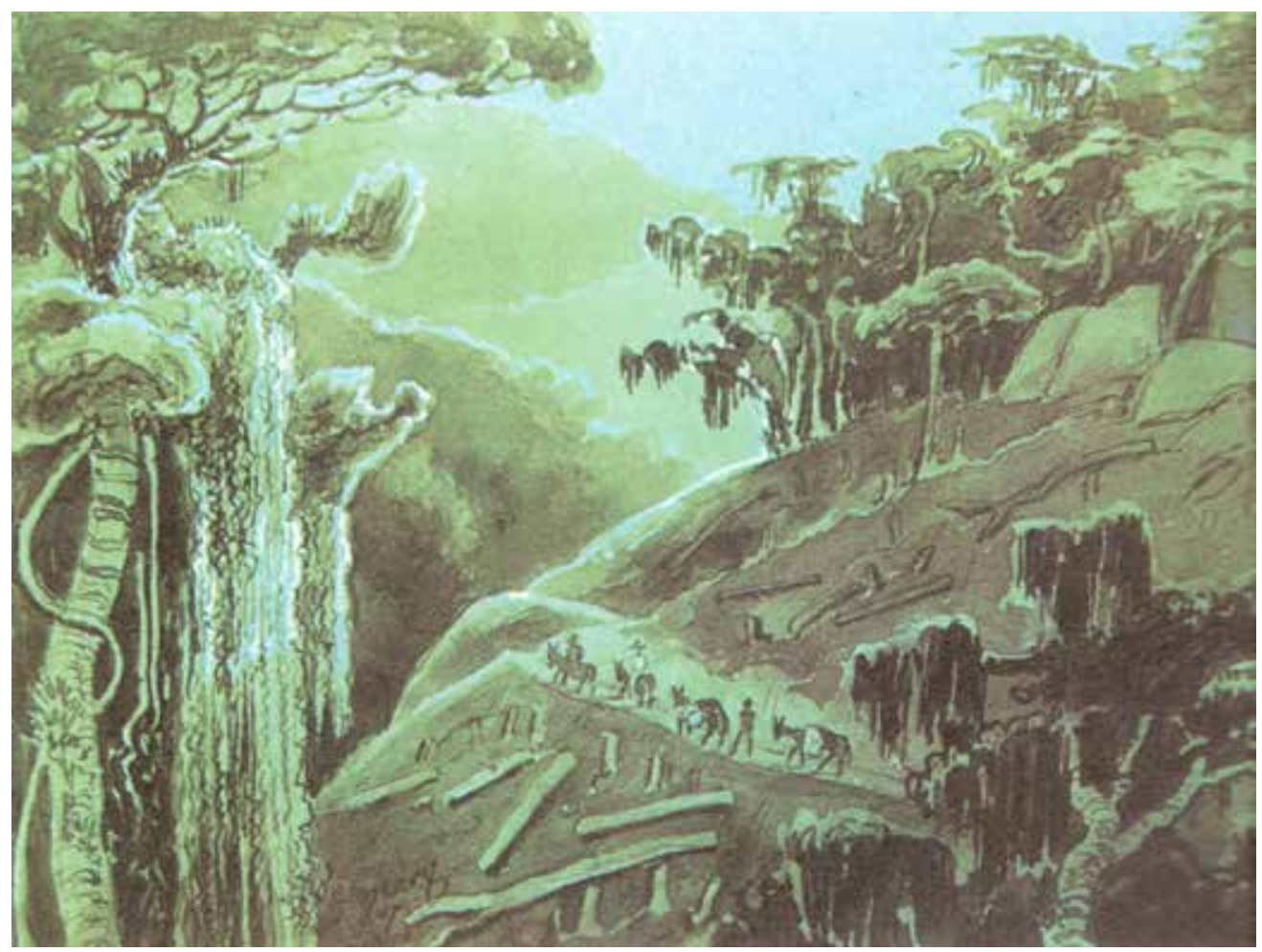

Figura 13 - Tropas de mulas galgando a Serra dos Órgãos. Note-se o desbastamento da mata próxima à estrada para favorecer a insolação e evitar os lamaçais. Benjamin Mary. Estrada na Serra do Mar, 1834/1838, sépia sobre papel azulado, 14×19cm, acervo do Museu Imperial de Petrópolis.
47. Cf. Luís Peixoto Lacerda Werneck (1855. p. 98). É preciso notar que, ainda que Verneck estivesse se referindo às agruras dos transportes em meados do século XIX, o país de então ainda era dependente de uma rede viária herdada, quase sem modificações, do período colonial. Agradeço a Rafael Bivar Marquese a indicação do texto de Verneck.

48. Para alguns números sobre o tamanho dos rebanhos e lotes de mulas comercializados no Brasil no século XIX, ver Herbert Samuel Klein (1990, p. 7-12). 
49. As rotas que ligavam os campos de criação no Rio Grande do Sul à Sorocaba foram estabelecidas também em função da ocorrência dos campos nativos, onde as mulas encontravam substanciosas pastagens. Ver Jaelson Bitran Trindade e João Urban (1992) e Rafael Straforini (2001). Esses campos nunca foram formados apenas por gramíneas, proliferando também inúmeras espécies de compostas e leguminosas, capazes de fornecer aos muares uma rica dieta em nutrientes que aliviariam a demanda por milho. Ver Ilsi Iob Boldrini (2010 p. 8-9), que faz referência a mais de 2.200 espécies campestres apenas no Rio Grande do Sul. Na medida em que tais campos iam perdendo sua diversidade florística, aumentava a necessidade de complementação alimentar das mulas, contribuindo para que milharais fossem ainda mais presentes nas paisagens rurais do sudeste e centro oeste do Brasil.

50. Deve-se o nome "quirerão" bem como seu uso no Vale do Paraíba ao culinarista João Rural.

51. Cf. Fernand Braudel (1995, p. 101).
A importância do milho na dieta dos muares aumentava conforme a qualidade das pastagens naturais diminuía. Em uma conjunção que pode não ter sido aleatória, o cultivo do milho ganhava força à medida em que as rotas das tropas deixavam os domínios das pradarias mistas sulinas. Ao afastarem-se das campanhas e coxilhas, cuja composição vegetal variada garantia uma rica alimentação para rebanhos de qualquer espécie, as tropas passavam a depender mais das rações de milho49.

As rações eram administradas a cada parada nos pousos e ranchos, que invariavelmente dispunham de milharais ou estoques de milho. Na realidade, as melhores paragens eram autossuficientes, dispondo de acomodações para os tropeiros, pastagens cercadas para os animais, além de roças e criações para a alimentação de homens e animais. Na economia dos pousos e ranchos, os milharais, além garantir a oferta da carne de porco e farinha aos tropeiros, também forneciam o milho em grão ou moído em moinhos para as mulas. Nesse último caso, tratava-se da moagem mais grosseira existente, que, no Vale do Paraíba, era chamada, significativamente, de quirerão ${ }^{50}$.

É difícil haver melhor exemplo da complexa interdependência entre os muitos elementos que compõem um sistema agrário do que a relação existente entre a agricultura comercial, os gêneros de abastecimento e as vias de comunicação antigas. No caso do Centro-Sul, essa interdependência parece, à primeira vista, aproximar-nos das teses buarqueanas sobre as relações entre o milho e a vida em trânsito. E, de certo modo, elas estão ali, mas não exatamente do modo que o grande estudioso formulou.

Novamente, não se trata aqui de postular relações causais diretas, tentando estabelecer primazias essenciais, um tanto deterministas. Trata-se sim de apontar a quase impossibilidade de fazê-lo, dadas as intrincadas inter-relações, as múltiplas dependências que pautavam o desenvolvimento dos sistemas agrários algo, às vezes, só possível por meio de uma análise histórica de longa duração.

Ainda que exageradamente estendidas, as considerações acima não seriam nunca capazes de esgotar o tema. Assim, intentam apenas mostrar o quanto ainda há de incerto sobre o variado "mosaico de formas de produção" outrora existente nas diferentes regiões brasileiras. E um dos mais promissores campos para novas pesquisas é, justamente, a investigação dos diferentes recursos e técnicas pelos quais se conformaram tais agriculturas ainda pouco conhecidas. Trata-se, como escreveu Fernand Braudel, de contar a história de sistemas agrários cujos funcionamentos eram extremamente complexos; sem deixar, no entanto, que um elemento predomine sobre os demais, pois nessa história, "tudo tem seu lugar, plantas, animais e pessoas" 51 .

E máquinas! poderíamos acrescentar à fala do mestre - em ousadia só justificável por seus fins ilustrativos. Porque raros foram os moinhos d'água brasileiros construídos em outras zonas que não essa ampla faixa do interior do país. Foi apenas dentro de seus incertos limites que sua faina incessante contribuía tanto para a alimentação de homens e mulheres quanto para a de seus animais - engordando porcos, aves domésticas ou preparando a ração das tropas de mulas. 
A complexa conjunção de fatores que tornaram os moinhos um fato tão incrustado nas paisagens rurais do Centro-Sul, impõe-se em definitivo ao se considerar que não há nenhuma causa meramente técnica capaz, sozinha, de explicar sua ausência nas demais regiões brasileiras. A mecânica hidráulica presente nas moendas de açúcar, por exemplo, era muitas vezes mais sofisticada do que a dos moinhos de fubá. E mesmo as desvantagens dos sítios nordestinos, desprovidos de cursos d'água acidentados, poderiam ser facilmente contornadas com a construção de pequenas represas ou barragens - técnicas que os séculos de dominação moura vulgarizaram por toda península ibérica ${ }^{52}$. Nem mesmo a ausência de ferro para engrenagens e fixação das partes ou a de boas pedreiras para as mós podem ser alegadas. No caso destas últimas, a presença de mós de trapiche, comuns em muitos engenhos de açúcar, já invalida o argumento ${ }^{53}$.

Em suma, apenas nas regiões em que todos os múltiplos fatores conseguiram se entrelaçar favoravelmente foi que os moinhos hidráulicos espraiaramse pelo território brasileiro. E a inventividade das formas, que encontram seus donos para continuar ainda hoje dispondo de seus velhos moinhos - mesmo em vista do desaparecimento das florestas nativas, da escassez de fabricantes de mós ou da míngua das águas dos ribeiros - é a prova maior da sua importância em nossas paisagens culturais.

Os moinhos de trigo e a "grande moagem" colonial:

Há um contraste notável entre a rapidez que marca a difusão dos moinhos a partir de sua adaptação ao milho e a letargia e circunscrição características da primeira fase da história dos moinhos hidráulicos no Brasil. Se nas páginas acima se procurou compreender os motivos por trás dessa rápida e ampla difusão, cabe agora discriminar as razões de tão lento avançar em seus primórdios. E ao fazê-lo, encontram-se regimes de moagem muito distintos em funcionamento em cada época, tanto em escala de produção como no uso econômico. E o que distingue claramente a moagem mais antiga é a escala muito maior em que operou, mesmo levando em consideração sua limitação à uma região e época muito específicas da América portuguesa.

Não são conhecidos registros de moinhos hidráulicos no primeiro século de colonização, sendo somente no século XVII que foram construídos os primeiros exemplares na colônia. Além disso, somente há menções esporádicas a moinhos d'água operando fora da capitania de São Vicente antes do início do século XVIII. A moagem de cereais seiscentista foi um fenômeno, exclusivamente, vicentino. E, mais particularmente, do planalto da capitania, pois foi somente no entorno das vilas localizadas na "serra-acima" que o velho maquinismo europeu se fazia presente. Cabia, então, a eles a tarefa de moer o trigo - cereal cuja presença em São Paulo sempre fora destacada tanto por antigos cronistas, como pelos historiadores locais. 
54. Ver Sérgio Buarque de Holanda (1957, p. 224-225).

55. Para um balanço crítico da historiografia sobre o período colonial em São Paulo, ver Ilana Blaj (2002, p. 39-85).

56. Ver John Monteiro (1994, p. 99-104).

57. Ibidem (p. 116-117).

58. Ibidem (p. 121).
A historiografia paulista (bem como os historiadores da técnica) sempre tendeu a postular uma continuidade entre esses primevos moinhos paulistas e os posteriores moinhos caipiras. Já Sérgio Buarque de Holanda via na posterior difusão dos moinhos, a partir do século XVIII, um exemplo de adaptação que os novos contextos coloniais impunham à difusão das velhas técnicas europeias. Só ao abandonar seu antigo papel de farinar o trigo, cultivo logo malogrado, e passar a moer o milho - gramínea nativa e de grande importância na colônia - que o moinho d'água passou a ter maior destaque na geografia humana do futuro país ${ }^{54}$.

Embora o quadro geral não se afaste muito do postulado de Holanda, é errôneo considerar que os moinhos de milho brasileiros apresentariam qualquer filiação com seus equivalentes seiscentistas em São Paulo. Ainda que essa hipótese se imponha fortemente no âmbito de abordagens difusionistas, ela parece não resistir a uma análise da técnica presente nas discrepâncias existentes entre os moinhos empregados em cada época. Essa diferenciação era devida, antes de tudo, aos diferentes contextos econômicos a que ambos os cultivos respondiam em seus tempos.

Ao contrário do ideal corrente no século passado, hoje sabemos que a cultura do trigo na São Paulo seiscentista cumpria funções muito distintas da suposta policultura de subsistência típica do povoamento do Planalto Paulista ${ }^{55}$. Tratava-se, sobretudo, de uma lavoura comercial alicerçada sobre a exploração da escravidão indígena e na conformação de um fundo agrário, que remontam à política desenvolvimentista de Dom Francisco de Souza, governador da repartição Sul da colônia na primeira década do séc. XVIII5. Nesse contexto, a produção do trigo nas vilas do Planalto surge como um dos mais rentáveis meios de inserir as elites locais nos circuitos mercantis do Atlântico. E não se tratava de uma produção pequena, mas sim de amplas searas que podem ter somado um montante anual entre 120 e 170 mil alqueires de farinhas de trigo - postas à venda, sobretudo, nas praças de Santos e Rio de Janeiro ${ }^{57}$. O recurso à moagem local cumpria um papel estratégico nesse comércio, já que as grandes distâncias eram o principal gargalo do sistema.

A travessia da Serra do Mar era, sem dúvida, o ponto mais crítico. Em uma época em que o Caminho do Mar se resumia a uma picada que só podia ser transposta por carregadores a pé, enviar à marinha o trigo já moído garantia uma folga indispensável na margem de lucro para os colonos de "serra-acima". Possuir um moinho hidráulico era, portanto, um empreendimento comercial de grande monta $^{58}$. Dificilmente, portanto, esses equipamentos se filiariam aos rústicos moinhos caipiras.

Se tais disparidades já tornavam improvável uma filiação entre os dois tipos de moagem, a descoberta das ruínas de um antigo moinho de trigo em Santana do Parnaíba, em 2013, evidenciou a grande diferença entre os dois processos. $O$ moinho em questão foi construído na década de 1620, e seus proprietários estiveram sempre ligados, direta ou indiretamente, aos grandes produtores de trigo de Parnaíba, a vila com os maiores trigais da capitania no século XVII. Embora o estado ruinoso da edificação não permita maiores detalhamentos sobre o seu maquinismo, faz-se claro que se tratava de um equipamento de grande porte. Na realidade, a robustez 
de sua alvenaria de pedra - técnica de rara utilização no passado colonial da região -, por si só, indica a imponência desse equipamento (Figura 14) e o volumoso trabalho a que era destinado 59 .

Ainda que seja preciso aguardar futuras pesquisas arqueológicas para se obter uma compreensão completa das soluções técnicas adotadas no moinho do Sítio do Morro, há nele alguns elementos que indicam diferenças consideráveis em relação aos pequenos moinhos de fubá. Em primeiro lugar, deve-se apontar a provável existência de um jirau de armazenamento, o que o pé-direito elevado das paredes permite inferir - conforme o desenho reconstitutivo procura demonstrar (Figura 15). Seria uma disposição muito útil para um moinho de grande porte, já que permitiria estocar sacas de farinhas e o "trem do moinho" - utensílios como pás, medidas de maquia, picadeiras e picões para as mós, além de peças e ferramentas para rápidos reparos. E embora quase toda essa equipagem também fosse utilizada nos pequenos moinhos, nunca se agenciava neles um espaço próprio, como parece ter sido o caso aqui. Em contrapartida, jiraus ou quartos específicos para estocagem de farinha e do trem do moinho são elementos comuns aos grandes moinhos europeus do mesmo período 60 .

Outro aspecto a indicar o grande volume de farinhas produzido no Sítio do Morro faz-se ver pela posição de um grande bloco de pedra dentro da parede em que se posicionava o moinho propriamente dito. Embora se desconheça ainda os detalhes, é certo que ali se apoiava um sistema de reforço para os barrotes do assoalho - no ponto sob a grande mó que servia de pouso para a pedra de cima.

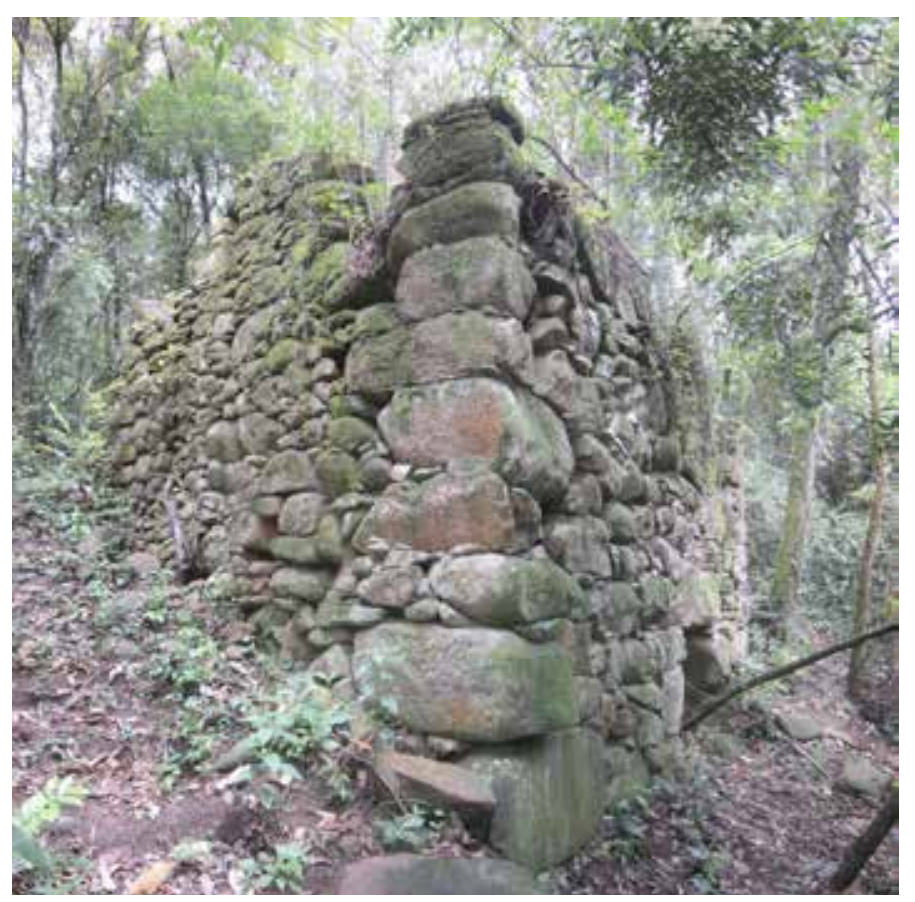

Figura 14 - Ruínas do moinho do Sítio do Morro, em Santana do Parnaíba, SP. Fotografia de Victor Hugo Mori, 2013.
59. Ver Francisco de Carvalho Dias (2014).

60. Em Portugal, tais disposições são típicas de moinhos intermediários, ver Ernesto Veiga de Oliveira; Fernando Galhano e Benjamim Pereira (1983, p. 211).

Annals of Museu Paulista. v. 23. n.1. Jan.-Jun. 2015.

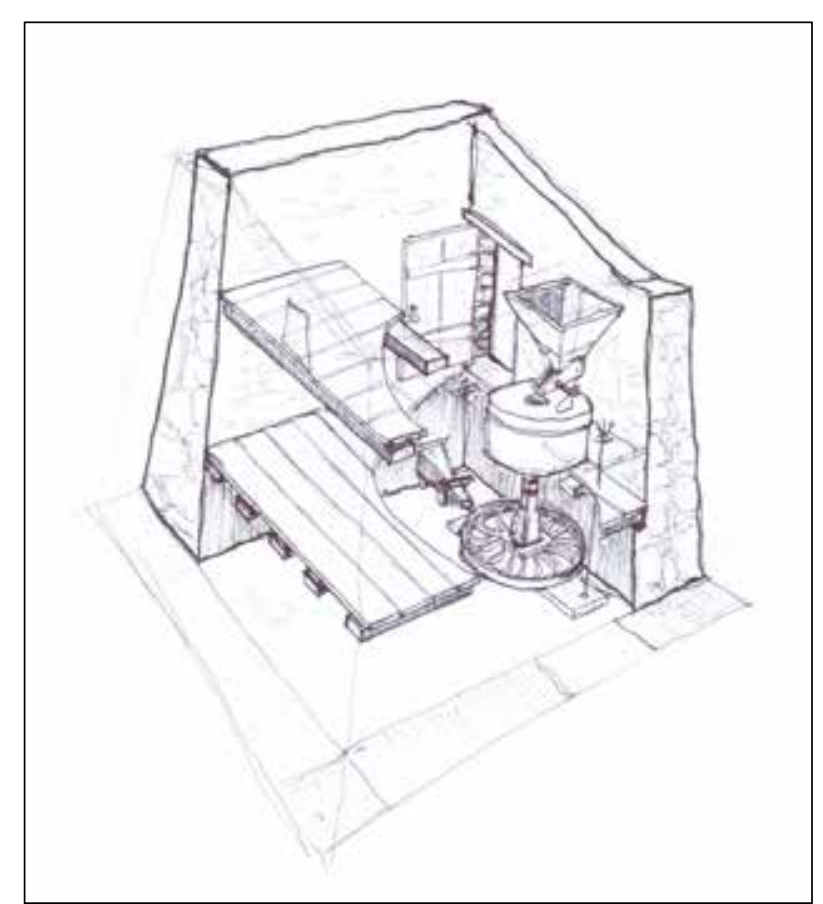

Figura 15 - Reconstituição hipotética das ruínas do Sítio do Morro. Desenho do autor. 
61. Para evidências consistentes de uma dieta alimentar mais diversificada em São Paulo durante o período colonial, ver Rafaela Basso (2008). Para usos e técnicas envolvidas no beneficiamento da mandioca e do milho em São Paulo no mesmo período, ver Francisco de Carvalho Dias de Andrade (2010, p. 114124 e 131-136).

62. Ver Rafaela Basso (2011, p. 68-73).

63. Exemplares dessas moendas manuais são ainda encontrados em antiquários - originárias normalmente de antigas fazendas de Minas Gerais. O Museu de Artes e Ofícios de Belo Horizonte mantém um exemplar desse equipamento, que muito raramente variava em suas formas.
Ao contrário dos moinhos menores, onde as mós se apoiam sobre uma "mesa" de madeira, aqui o pouso se apoiava diretamente no assoalho, em solução também usual nos moinhos europeus de maior porte - a posição da grande pedra no interior da parede, bem como a da linha do antigo assoalho são apontadas na (Figura 16). Ainda que, até o momento, não se tenha encontrado as pedras pertencentes ao moinho no sítio, sabemos que se tratava de mós de tamanho invulgar. Há muito se conhecem alguns exemplares de mós congêneres, todos pertencentes a antigas propriedades seiscentistas da região - o que permite uma aproximação segura -, e sobre os quais voltaremos a falar mais à frente.

Sendo evidente a discrepância entre os maquinismos, somente se poderia alegar que a técnica em si (a moagem do milho em mós giratórias) teria sido aprendida em São Paulo e depois difundida para o resto do país. Contudo, não há nenhuma evidência de que o milho tenha sido moído em São Paulo durante o século XVII. Ainda que essa ideia esteja implícita nos argumentos de Sérgio Buarque de Holanda, novos estudos em história da alimentação vêm questionando a prevalência de uma "civilização do milho" em São Paulobl. O consumo do milho não só se dava em concomitância a diversos outros alimentos, como havia grupos populacionais inteiros que não tiveram no cereal americano senão um alimento secundário e ocasional.

Mesmo entre as camadas populacionais em que o consumo do milho como alimento-base é um dado certo, não se encontra sinal algum de que era consumido moído, muito menos que a moagem era feita nos mesmos moinhos de trigo. A própria inexistência de uma palavra de origem portuguesa ou indígena para o milho moído é um sinal de que ele não existia em São Paulo antes da introdução maciça da escravidão negra, processo que só ganha força ao longo do século XVIII. Teriam imperado aqui os hábitos culturais herdados. Como apontou a historiadora Rafaela Basso, grande parte da população escravizada presente nos tijupares das fazendas paulistas era de procedência guarani, que teria continuado a preparar e consumir o milho de acordo com o costume tribalo2.

Outro argumento a reforçar a tese é a inexistência da moagem doméstica em São Paulo no período. Não é conhecida qualquer referência, nos inventários post-mortem seiscentistas, das pequenas moendas braçais utilizadas para o consumo doméstico de farinhas, ainda que não tenham sido uma alfaia rara em outros contextos coloniais. Mesmo em Minas Gerais, durante os sécs. XVIII e XIX, era comum encontrar moendas manuais tanto em casas urbanas como rurais, onde eram usadas para moer o milho (Figura 17/63. Se em terras paulistas o caráter comercial da cultura do trigo impunha fortes restrições às moendas domésticas, elas desapareciam totalmente ao se passar ao cereal americano. E ainda assim, a ausência da moagem doméstica prevalece, indicando que o milho não foi consumido moído em São Paulo de forma significativa.

Ainda que se considerem outros tipos de restrições, elas ainda são insuficientes para esclarecer esse problema. Sabemos, por exemplo, que havia algumas proibições para a posse e operação de moinhos nas colônias. Mas elas 


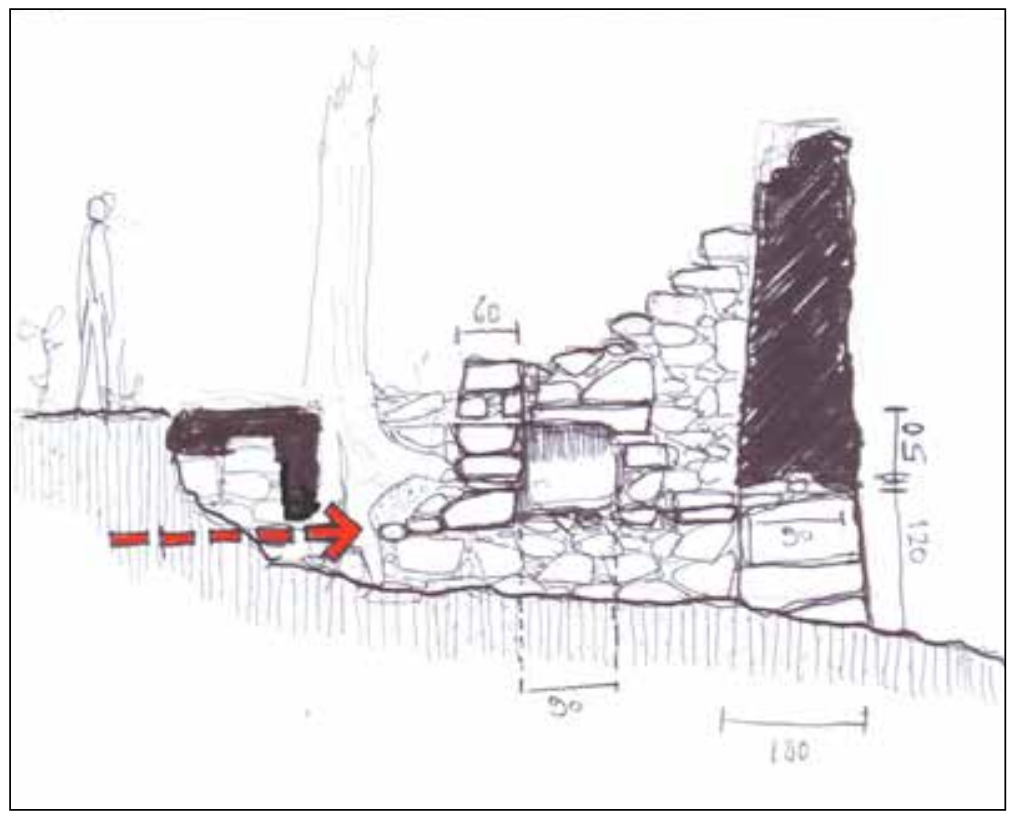

Figura 16 - Corte das ruínas mostrando a posição da grande pedra que ajudava a suportar as mós do moinho. Desenho do autor.

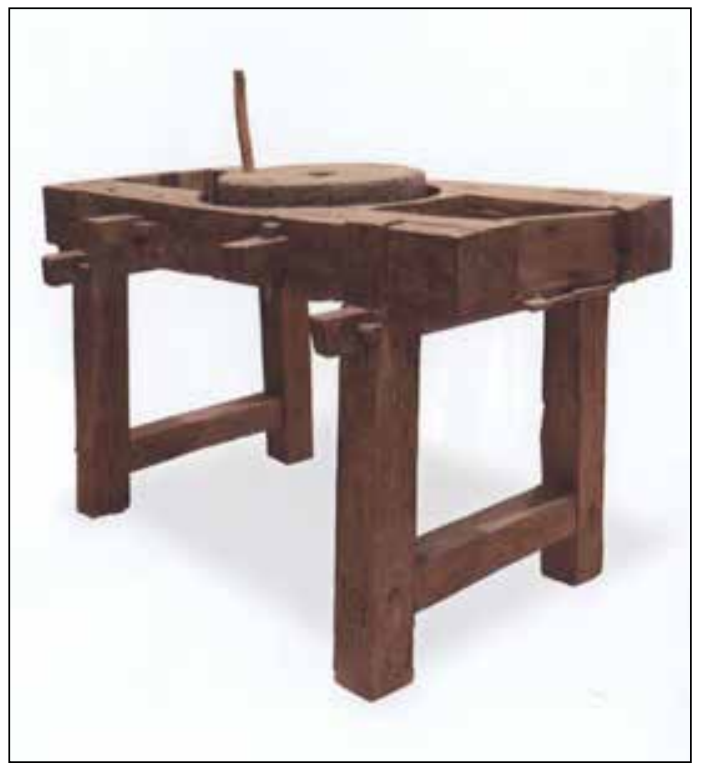

Figura 17 - Moenda manual para fazer fubá. Século XIX, madeira e pedra, coleção particular. Fonte: Emanoel Araújo (2013). incidiam, costumeiramente, sobre o beneficiamento de produtos agrícolas comerciais. E mesmo no caso em que comercialização e subsistência eram fins comuns a um mesmo cultivo, a legislação estabelecia atenuantes. Foi este o caso dos Açores, onde o beneficiamento do trigo a ser vendido era privilégio de moinhos senhoriais, mas pequenas moendas braçais de uso exclusivamente doméstico eram de posse livre ${ }^{64}$.

Os argumentos apresentados acima ajudam a consolidar a existência em São Paulo, durante o século XVII, de uma moagem de maior porte, originada do caráter comercial próprio ao cultivo do trigo na capitania. A moagem seiscentista em São Paulo, na realidade, teria sido o único momento em que houve no Brasil colonial uma grande moagem de cereais, conforme esse termo costuma ser utilizado no contexto europeu 65 .

Os moinhos da vila de São Paulo: da moagem urbana à moagem rural

Se na questão da adaptação das mós rotatórias para a moagem do milho a legislação colonial parece ter tido pouca ou nenhuma influência, em outros aspectos desses primeiros tempos da moagem no Brasil, sua influência foi decisiva. Desse modo, mesmo que o caráter comercial da lavoura do trigo tenha contribuído muito para a baixa difusão dos moinhos, o aspecto econômico não era o único fator nessa equação. A peculiar situação administrativa da capitania parece ter influído fortemente na questão com consequências importantes para os estabelecimentos urbanos e rurais nos quais a moagem se fazia presente.
64. Ver Ernesto Veiga de Oliveira; Fernando Galhano e Benjamim Pereira (1983, p. 32).

65. Não se pretende aqui uma comparação, em termos de volume e técnica, entre a moagem colonial e a "grande moagem" europeia da Baixa Idade Média e inícios da Idade Moderna tendo em vista a distância abissal existente aí entre as duas. Entre essas, mesmo assim, há algumas similaridades em termos de organização econômica e administrativa das técnicas, como certa centralização na posse dos moinhos por leis restritivas e/ou distorções econômicas e $\mathrm{o}$ fator determinante da comercialização das farinhas em mercados urbanos algures. Em ambos os casos, tais pressões foram determinantes para a configuração de moinhos de maior sofisticação técnica e capacidade operativa. Sobre a grande moagem na Europa no período referido ver Abbott Payson Usher (1993, p. 242-244). 
66. Ver Pedro Taques de Almeida Paes Leme ([s.d.], p. 159).

67. Cf. Actas... (II, p. 363).

68. Cf. Idem (II p. 377).

69. Não há menção ao "asento" ou "quintal" do moinho, pois toda a ampla faixa de terrenos que hoje forma os bairros de Casa Verde e do Limão já pertencia a Amador Bueno, por meio de seu casamento com a filha de Salvador Pires, sesmeiro na região. A menção a "mea legoa" nos autoriza a supor que o moinho dos Buenos se localizasse próximo à atual Av. Imirim - região em que o leito do Mandaqui passa a cortar os terrenos mais acidentados e onde nascem alguns de seus formadores.

70. Ver Manuel da Fonseca (1932, p. 106).

71. Ver John Monteiro (1994, p. 113).
Por ser uma capitania donataria em São Vicente, o monopólio da moagem vigorou até 1709, quando a capitania foi comprada pela Coroa. Como fora estipulado desde a carta foral de Martim Afonso de Souza, nenhum morador da capitania poderia possuir um moinho sem a autorização do donatário - ou da câmara, a quem era delegada a função de distribuir tais licenças ${ }^{66}$.

A antiga documentação camarária paulistana guarda algumas atas de sessões e registros de doação de datas de terras para a instalação dos primeiros moinhos no termo da vila no século XVII. Esses moinhos paulistanos foram construídos a partir da década de 1610 e eram intimamente vinculados ao ambicioso projeto de Dom Francisco de Souza de criar aqui "uma segunda Potosi". A instalação dos primeiros moinhos de trigo na vila de São Paulo, portanto, visava viabilizar a empresa agroindustrial encabeçada por Dom Francisco. Desse modo, compreendese a localização um tanto anômala do primeiro moinho, cuja instalação autorizada pela Câmara, em 1614, concedeu, além da licença do uso das águas do riacho Mubuquisaba, uma data de 60 braças em quadra para o "sítio do moinho" 67 . $\bigcirc$ equipamento teria pertencido a João Fernandes Saavedra e era localizado no caminho de Jeribatiba - possivelmente, nas proximidades do engenho de ferro do Ibirapuera, peça-chave nos planos do governador.

Não se sabe ainda se o moinho de Saavedra chegou a ser construído, mas caso o tenha sido, teve uma influência restrita ao bairro de Santo Amaro, que esteve longe de se destacar na produção de trigo da região. Os maiores trigais localizavam-se nos bairros rurais que foram se formando na margem direita do Tietê, "a banda dalém", e, principalmente, na região à jusante da confluência com o Pinheiros, já no rumo dos sertões de Barueri e Parnaíba. Em 1616, Amador Bueno requereu autorização da câmara para construir um moinho no córrego Mandaqui, na "outra banda do rio grande mea legoa pella terra demtro" 68 . A câmara concede a licença mediante o pagamento de uma taxa anual de dois vinténs ${ }^{69}$. $\bigcirc$ moinho dos Buenos foi, com certeza, um equipamento importante em seu tempo. A antiga fazenda do Mandaqui é citada já por Manuel da Fonseca entre as grandes propriedades de seu tempo, contando com numeroso plantel de índios administrados ${ }^{70}$.

O moinho instalado por Amador Bueno no Mandaqui apontava o padrão que posteriormente a moagem adquiriria nos bairros rurais triticultores: o de moinhos de rodízio senhoriais que tiravam vantagem de sua boa implantação no terreno para suprir a ausência de mecanismos mais sofisticados e visavam manter o beneficiamento e comercialização do trigo sob controle de um grupo restrito de vizinhos. Trata-se dos mesmos princípios que parecem ter regido também a construção e a operação do moinho do Sítio do Morro, em Santana do Parnaíba. E ambos os casos aproximamse do que foi se tornando o padrão da moagem seiscentista - principalmente durante o apogeu da triticultura vicentina, ocorrido entre as décadas de 1630 e $1680^{71}$.

Na vila de São Paulo de Piratininga, contudo, esse tipo de moinho foi uma exceção nos primeiros anos da moagem. Dispor de moinho em terras próprias, e ainda a quilômetros de distância do ramal de caminhos que tinham a sede da vila como tronco, só era acessível a poucas pessoas. Não por acaso, a São Paulo 
do início do século XVII, foi a vila cuja paisagem urbana foi mais fortemente marcada pela presença de moinhos hidráulicos no século XVII. Ainda que Santana do Parnaíba (e talvez Taubaté) tenham tido moinhos em seus termos, foi a vila de São Paulo que conheceu o maior número de moinhos operando no rocio da vila ${ }^{72}$.

Na mesma ocasião em que Amador Bueno requereu a licença para usufruir das águas do Mandaqui, Cornélio de Arzão e Manuel João Branco também foram à câmara requisitar privilégios semelhantes no Anhangabaú. $\bigcirc$ primeiro declarou a intenção de "fazer hu moinho em hu asento que esta no ribeiro que vai de santo antonio abaixo de san bento"73. A referência à ermida de Santo Antonio e ao convento beneditino certifica ser mesmo o Anhangabaú o ribeiro escolhido por Arzão. Bem próximo ao Mosteiro de São Bento, o Anhangabaú recebia o reforço das águas do córrego do Acu, o que fazia desse ponto um dos mais vantajosos para a instalação das pás de um moinho. Ainda que de pouca monta, o reforço das águas do Acu deveria ser de fundamental importância no moinho de Arzão, já que ali o Anhangabaú corria quase em mesmo nível ao Tamanduateí, conforme se vê nos antigos mapas da cidade (Figura 18).

Já no caso de João Manuel Branco - que requereu à câmara licença para fazer logo dois moinhos - a descrição contida nos registros é um tanto confusa, mas alguns preciosos e raros documentos iconográficos permitem aferir sua localização no córrego do Bexiga. Não há dúvidas quanto à sua localização no Anhangabaú, pois estão ambas as máquinas assinaladas no desenho da vila de São Paulo que acompanha mapa de Alessandro Massaii, "CAPITANIA. DE.S.VICENTE". Ocupam eles o mais à esquerda do desenho, onde se distinguem as casas dos moinhos, acompanhadas das legendas "moinho de mel joam" (Figura 19). Ambas as casas dos moinhos estão dispostas sobre o curso d'água referido como "anhangavábahu"74. A altura em que os moinhos estão postos no córrego, bem como a clara inflexão apresentada pelo seu curso, indica que não se localizavam no Anhangabaú propriamente dito, mas sim em um de seus formadores da margem esquerda, os córregos do Saracura e do Bexiga.

A confirmação de que se trata do córrego do Bexiga é possível pelo cotejamento com outra rara peça iconográfica, o "Dezenho por îdea da çîdade de Saõ Pavlo", de autoria desconhecida, mas feita entre 1765 e 1775. Esse importante desenho é o melhor registro visual da cidade de São Paulo anterior ao programa de construções públicas e remodelamento arquitetônico que teve início no governo do Morgado de Mateus ${ }^{75}$. É um valiosíssimo documento sobre o aspecto da cidade não só na época em que foi feito, mas fiel também a formas mais antigas.

O ritmo de transformação da cidade era lento o suficiente para que ambos os moinhos de Manuel João ainda conseguissem ter algum destaque na composição do desenhista. No canto inferior mais à direita da composição, aparecem as duas casas dos moinhos já incorporadas a uma chácara então existente no local - conforme se vê na Figura 20. A disposição do terreno permite distinguir claramente os formadores do Anhangabaú: o ltororó na parte de cima (identificado como o Anhangabaú propriamente dito pelo desenhista) e o Saracura
72. A existência de moinhos de trigo no rocio da vila de Taubaté fica subtendida a partir de relato de Pedro Taques de Almeida Paes Leme. Faltam, contudo, quaisquer outras referências mais sólidas sobre o assunto. Ver Pedro Taques Almeida Paes Leme ([s.d.], p. 150). Já em Santana do Parnaíba, há referências a moinhos operando dentro de terras do rocio, aonde chegou a existir uma Rua do Moinho.

73. Cf. Actas....(II, p. 369).

74. O desenho de Massaii traz para os topônimos tupis uma tradução em português. No caso do ribeiro, o sentido referido por Massaii é "agoa do rosto do diabo". Trata-se de um étimo, ao que parece, ainda desconhecido até agora nas tentativas de discernir a etimologia do termo. Ao sentido registrado por Massaii, poderia-se remeter as formas anhangá $+t o b a ́+b u$.

75. Ver Nestor Goulart Reis Filho (2004, p. 235). 
logo abaixo. Os dois cursos têm seu encontro assinalado logo a jusante dos moinhos, onde posteriormente seria construída a ponte do Lorena. Em meio as elevações do terreno traçadas entre os dois riachos pelo autor anônimo, podemos inferir o talvegue do córrego do Bexiga - onde, em um ponto mais alto, o moinho a montante ia buscar as águas, que eram, em seguida, direcionadas para a máquina mais abaixo. Uma disposição, inclusive, em concordância com o tracejado ligando um moinho ao outro no desenho de Massaii.

Com essas referências em mente, torna-se mais fácil esclarecer a descrição contida na carta de datas de 1616, na qual Manuel João Branco declara sua intenção de:

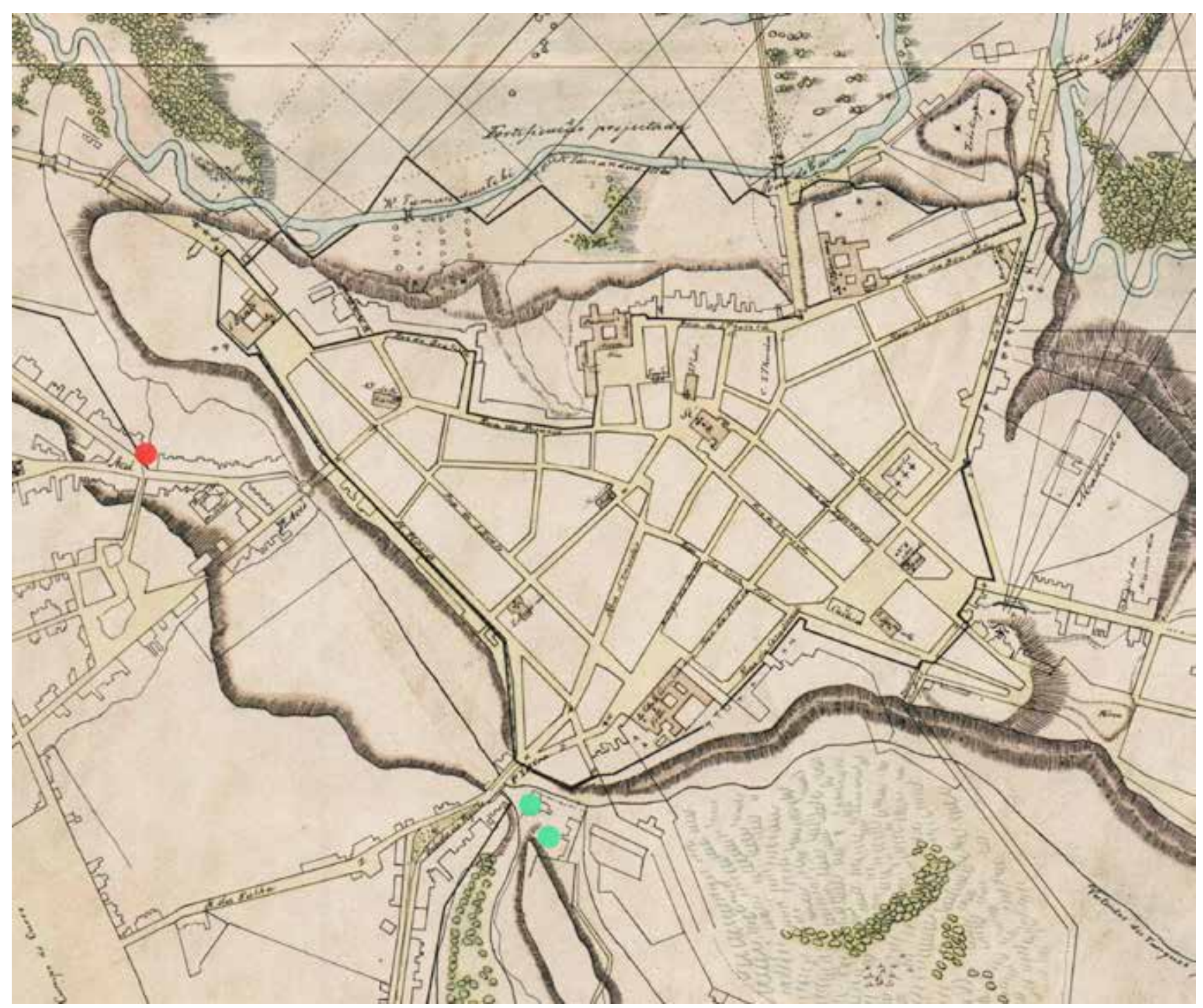

Figura 18 - Possível localização dos dois moinhos de Manoel João Branco (em verde) e de Cornélio de Arzão (em vermelho). José Jacques da Costa Ourique. Carta da capital de São Paulo, 1842, nanquim sobre papel, 648x877cm. Acervo do Arquivo Histórico do Exército. 


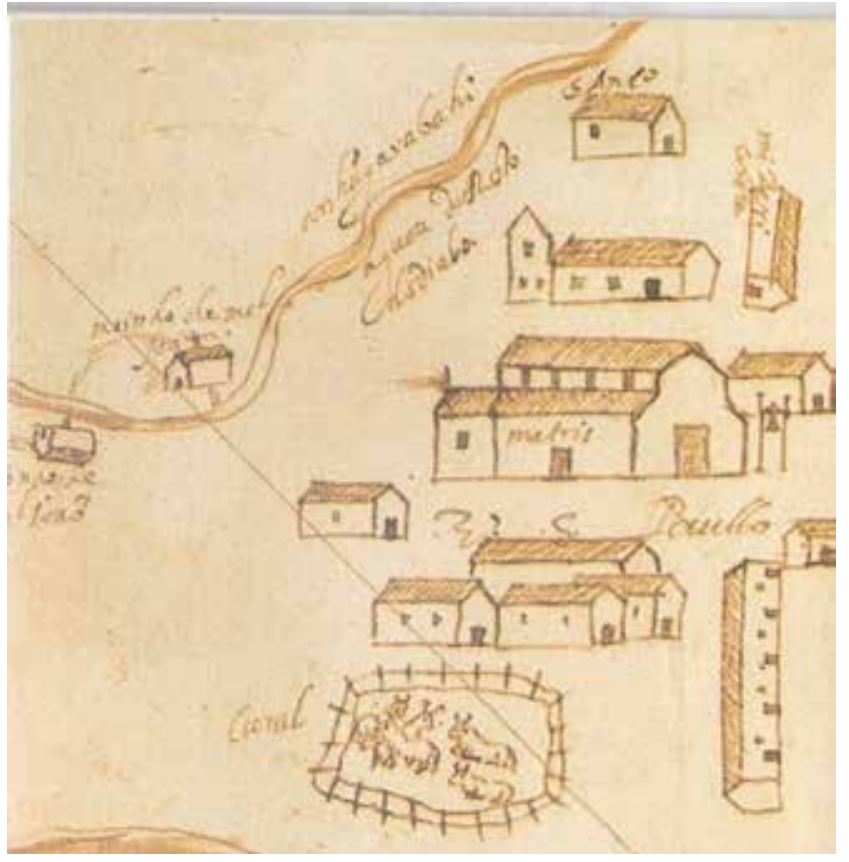

Figura 19 - Detalhe de desenho da vila de São Paulo em que se pode ver os dois moinhos de Manoel João Branco no córrego do Bexiga, um dos formadores do Anhangabaú. Alessandro Massaii. Capitania de S. Vicente, ca. 1616, tinta aquarelada sobre papel, $28 \times 40 \mathrm{~cm}$. Acervo da Real Academia de História de Madri.

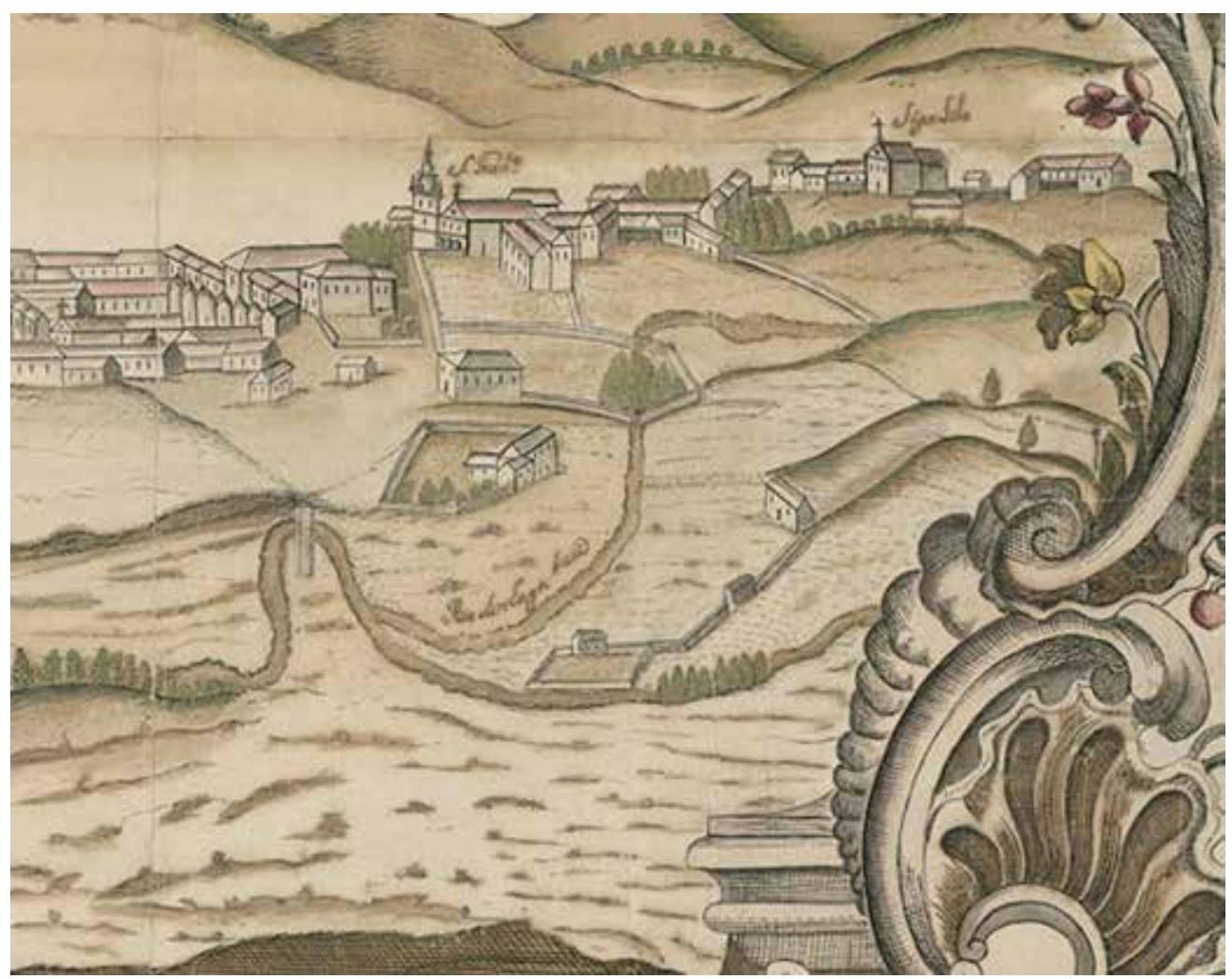

Figura 20 - As duas casas dos antigos moinhos de Manoel J. Branco no córrego do Bexiga. Autor anônimo, detalhe do Dezenho por îdea da çidade de Saô Pavlo, 1765/1775, nanquim sobre papel, $74 \times 58 \mathrm{~cm}$. Acervo da Biblioteca Nacional (disponível em: <bndigital.bn. br>). 
76. O confuso teor poderia ser adaptado nos seguintes termos: [fazer dois moinhos em uma mesma água que, saindo do cabouco, é conduzida a outro moinho, ambos na banda além da de Bartolomeu Gonçalves]. Essas águas nascem na tapera de Diogo Gonçalves Lasso - com um braço na banda além e outro na banda de Bartolomeu Gonçalves. Cf. Actas...(II, p. 374). Sabe-se que Bartolomeu Gonçalves tinha sua casa "atraz de Santo Antonio (...) no caminho que vae para os Pinheiros", ou seja, na margem direita do Anhangabaú, ou mais propriamente dito, no trecho final do Itororó. A banda dalém seria, portanto, justamente o lado onde está o córrego do Bexiga. Seriam o Itororó e o Bexiga os braços mencionados como nascentes na tapera de Diogo Gonçalves. Cf. Cartas... (VI, p. 15-16).

77. Ver Francisco de Paula Dias de Andrade (1966, p.62-63).

78. Cf. José Carlos Vilardarga (2010, p. 154).

79. A penúria técnica da vila, nos primeiros tempos, fora tanta que seria errôneo crer que haveria ali gente capacitada para construir moinhos, senão os mais rudimentares. Não é possível corroborar o juízo de Fernão Cardim que atribuía a ausência de grandes searas no planalto em 1585 à falta de moinhos para moer o trigo. Ver Fernão Cardim (1997, p. 161).

80. Ainda está por ser escrita a história da contribuição das levas de artesãos qualificados que chegaram à vila de São Paulo no período de 25 anos que vai da parada da frota de Valdez em Santos, em 1581, à chegada de Dom Francisco, em 1608. A crônica antiga e pesquisas afins nos "fazer dous moinhos em hua agoa saindolhe do caboulo a outra parte fazer outro da banda dalém de Bertolomeu Glz as quais agoas nascem na tapera de Dioguo Glz Lasso da banda dos Pinheiros, hú da banda dalém, houtro da banda de Bertolameu Glz e teras pera hu quinta|"76

A menção ao "cabouco" que conduziria a água de uma parte à outra se justifica plenamente nos trâmites da legislação ibérica colonial, já que conflitos decorrentes da superexploração de rios e ribeiros foram constantes em Portugal e na Espanha. Principalmente durante os meses secos do verão mediterrânico, a baixa dos rios ocasionava acirradas disputas entre donos de moinhos ou entre moleiros e agricultores que dependiam da mesma fonte de água para irrigar seus campos. Desse modo, considerando que Cornélio de Arzão instalava concomitantemente um moinho "abaixo de sam bento", era mister que os maquinismos Anhangabaú acima operassem sem prejuízo para o do flamenco, ou seja, reaproveitando a mesma água e despejando-a novamente no curso do córrego.

A construção de moinhos hidráulicos no rocio da vila não fazia deles um bem ou edifício urbano, já que era o uso e não a localização que definia o caráter de uma construção na legislação colonial. Assim, lugares como currais, áreas de pesca, equipamentos de beneficiamento agrícola eram todos considerados como edificações rurais - mesmo quando localizados dentro dos limites do rocio ou em área já arruada e edificada ${ }^{77}$. Ainda assim, a presença de moinhos de trigo operando em terras da câmara, ao menos em São Paulo, adquire, aos olhos de um observador atual, ares de verdadeira atividade urbana, como se faz ver no "Dezenho por îdea".

Um último aspecto que deve ser apontado na história desses primeiros moinhos paulistanos é o de terem sido empreendimentos capitaneados por "homens mecânicos". Tanto Manuel João Branco quanto Cornélio de Arzão integravam a comitiva de técnicos em mineração de Dom Francisco de Souza ${ }^{78}$. Eram, portanto, plenamente capazes de erguer um bom moinho d'água, já que a maior parte dos maquinismos empregados na mineração e produção do ferro dependia da força hidráulica. No caso de Amador Bueno da Ribeira, cabe lembrar que seu patronímico resulta da incorporação da alcunha do pai, Bartolomeu Bueno, carpinteiro da ribeira de Sevillha. Assim, ainda que Amador não tenha exercido o ofício de carpinteiro, é bem provável que não fosse leigo na arte.

Sabe-se que a vila de São Paulo contou com carpinteiros e ferreiros entre seus moradores desde seus primeiros anos; foram eles artesãos de qualificação muito inferior à dos mecânicos em questão ${ }^{79}$. Entretanto, parece claro que a existência da "grande moagem" no planalto, durante o século XVIII, só se fez possível com a chegada de artesãos qualificados como Arzão, Manuel João, Bartolomeu Bueno e tantos outros ${ }^{80}$.

A partir da segunda metade do século XVII, já durante o apogeu da economia do trigo, o exercício da técnica passou a depender fortemente de 
escravos artesãos pertencentes a oficiais livres que arrematavam obras, fossem públicas ou particulares. Nos primeiros anos do século XVII, todavia, o cenário fora em tudo diferente, e o saber técnico era, então, circunscrito a alguns poucos homens. E com o incremento da economia rural da região, tais homens, não raro, fizeram de seu "defeito mecânico" a base para sua elevação social nas vilas de "serra-acima" - como foi o caso dos Buenos, de Cornélio de Arzão e de Manuel João Branco.

Moinhos coloniais, técnicas mediterrânicas: a importância da terminologia

Dentre as maiores contribuições para a historiografia da técnica no Brasil, há de se destacar os importantes trabalhos dos arquitetos Ruy Gama e Júlio Katinsky, em que ambos procuram estabelecer as bases para uma terminologia das técnicas tradicionais no país ${ }^{81}$. Abordando os moinhos de fubá caipiras em particular, Katinsky apontou para o fato de que quase todos os elementos e partes dos moinhos têm nomes derivados do latim. No caso dos moinhos horizontais, a procedência latina da nomenclatura é ainda maior: rodízio (roticinus), veio (vena), eixo (axis), segurelha (cura), tempereiro (do verbo temperare), moega (modium) são alguns exemplos que podemos citar.

A terminologia presente nos moinhos hidráulicos brasileiros, ainda de acordo com Katinsky, é praticamente a mesma usada até hoje em Portugal. E notável também é a persistência morfológica dos termos mais importantes, que pouco variaram desde a Baixa ldade Média lépoca a partir da qual a nomenclatura técnica se fez mais frequente nos registros escritos). Mesmo no Brasil colonial, onde a ausência das rígidas normas das corporações de ofício poderia contribuir para uma maior desorganização do vocabulário, verifica-se a mesma persistência dos nomes herdados da Europa. No inventário de Manuel João Branco, o mesmo que instalara dois moinhos no Bexiga, redigido em 1643, foi inventariado outro de seus moinhos. $\bigcirc$ moinho foi encontrado pelos avaliadores já desmontado, condição que permitiu uma rara descrição mais pormenorizada das partes componentes do moinho. Além de aos jogos de mós, faz-se menção no documento aos "arcos de ferro do rodisio" a "um veio com a sua segurelha", atestando assim a circulação da terminologia latina desde os primórdios da moagem no Brasil ${ }^{82}$.

$\bigcirc$ outro único inventário conhecido que traz uma descrição mais detalhada dos elementos dos moinhos seiscentistas, contudo, apresenta um enigma de difícil solução. No inventário de Antonio de Souza Couto, aberto em Santana do Parnaíba, em 1652, foi avaliado "hu moinho con a caza cuberta de telha com dous siconis e duas picadeiras" 83 . $\bigcirc$ enigma em questão é o significado do termo "siconis", que não consta em nenhum dicionário de português ou espanhol, tanto antigo como moderno.

A resposta para esse problema aponta para a existência de cenários iniciais mais complexos na base da herança técnica brasileira do que a origem latina dos termos vem indicando. permitem relacionar, ao menos, a conclusão da igreja Matriz da vila por Cornélio de Arzão, o arruamento das ruas Direita e São Bento, cuja intersecção ortogonal era conhecida como "os quatro cantos" e o engenho de ferro de Ibirapuera.

81. Ver Ruy Gama (1982) e Júlio Roberto Katinsky (1985. p. 216-242).

82. Cf. Inventários...(XIII, p. 306).

83. Cf. Inventários...(XLIV, p. 247). 
84. Ver Ernesto Veiga de Oliveira; Fernando Galhano e Benjamim Pereira (1983, p. 150-153).

85. Cf. Joan de Corominas (1954, v. IV, p. 166, linha 28), Verbete SAETÍA.

86. Ver Joam de Corominas (1954, v. IV, p. 166, linhas 35-36) verbete SAETÍA.
Em uma análise morfológica do termo nota-se que sua raiz, provavelmente, deriva da palavra grega para "figo" (sykon/ бúкov) ou "figueira"

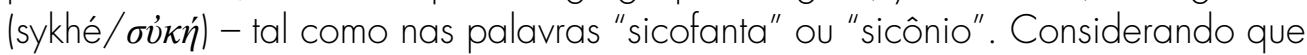
o termo registrado no inventário de Parnaíba está no plural, podemos aferir que o substantivo singular seria siconil. Estaria, portanto, ainda mais próximo do sykon grego, acrescentando-se apenas o sufixo il, próprio aos nomes de lugar ou depositório na língua portuguesa.

Mesmo que a procedência grega do termo seja bem provável, permanece ainda ignorado qual elemento do moinho nomeava. Sem falar que outra resposta se faz premente: uma vez que se trate de um elemento comum a qualquer moinho horizontal, por que não há nenhum outro registro do termo siconil, ou siconis na literatura especializada antiga e moderna?

A hipótese que aqui se levanta é que siconil seria um arcaísmo já em desuso no século XVII. E teria sido usado (talvez apenas localmente) para designar a seteira dos moinhos: o orifício pelo qual a água é direcionada ao rodízio, não raro acompanhado de um apetrecho regulador da força do esguicho.

A seteira é uma das partes dos moinhos horizontais que apresentam um grande número de soluções construtivas, recorrendo à carpintaria, à alvenaria de pedra ou ao cimento - nos exemplares mais novos. Entretanto, mesmo nos dois últimos casos, se recorre sempre ao uso da madeira para construir o regulador do jato, que arremata a estrutura sob a forma de torneiras, portinholas ou funis ${ }^{84}$. Exemplos de alguns tipos bem comuns de "seteiras" em Portugal podem ser vistos nos belos desenhos de Fernando Galhano (Figura 21).

Embora "seteira" seja de uso cotidiano em Portugal - e presente também na literatura especializada -, o termo é uma corruptela de formas mais antigas em nada relacionadas com o sentido de "seta" ou "flecha". O termo original é sétia ("setía" ou "sitía" na fala brasileira mais comum) e, ao contrário do termo "siconil", seu uso é amplamente distendido no tempo e no espaço. $\mathrm{Na}$ Espanha, "saetía" é palavra antiga (o primeiro registro data de 1543) e amplamente empregada com o mesmo fim, derivando também para a América durante a colonização ${ }^{85}$

Sétia ou saetía não seriam termos apenas de circulação ibérica. Seu aparecimento na península, inclusive, pode ter sido mais tardio, já que os primeiros registros surgem ao leste. A palavra saetie consta no francês já em 1246 (tendo sido talvez derivada de um similar occitânico) e a forma saettia foi registrada em Gênova, já em 1 101, marcando a primeira documentação do termo em uma língua românica ${ }^{86}$. Trata-se, portanto, de uma palavra de circulação mediterrânica cujos marcos cronológicos apontam para seu surgimento em forma romance no norte da ltália, difundindo-se daí para as costas ocidentais do grande mar interior.

A hipótese aqui proposta é que a difusão das formas derivadas do italiano saettia acabou por substituir o termo sinônimo siconil - que, como se verá adiante, pode dever seu uso em Portugal, ainda nos sécs. XVI e XVII, a circunstâncias históricas muito particulares ao país. 


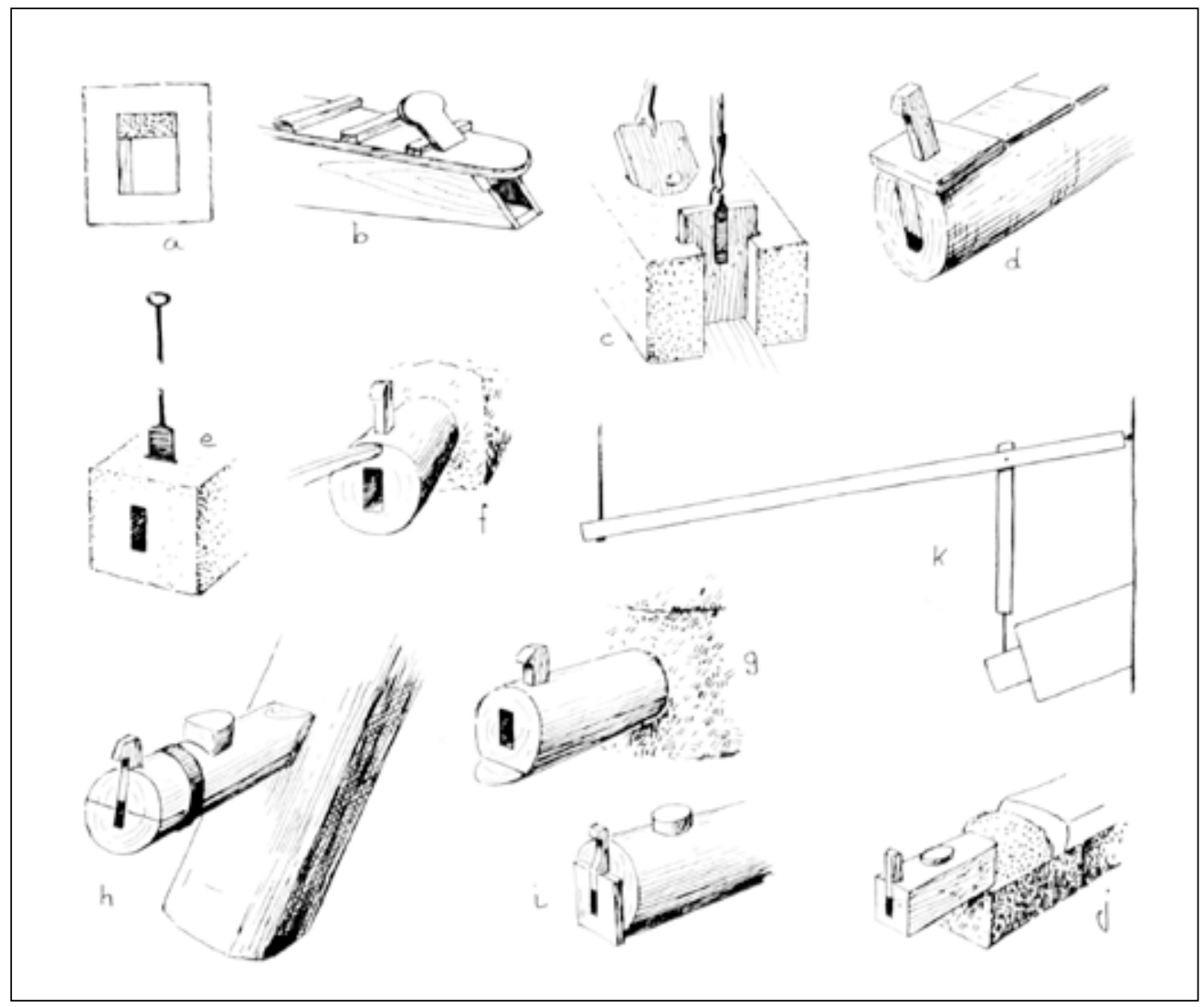

87. Apud Joam de Corominas (1954, p. 166, linhas 44-48) verbete SAETÍA.

Figura 21 - Tipo de seteiras portuguesas com dispositivos de regulagem da saída da água. Fernando Galhano. Seteiras, nanquim sobre papel, [s.d.]. Fonte: Fernando Galhano (1985).

Para recompor a trajetória histórica dessas palavras um tanto obscuras, faz-se necessário dizer que eram como termos náuticos - e não como nome de peça de moinhos - que as formas saettia/saete/saetía estão registradas nos documentos antigos. Há, inclusive, um curioso registro desse uso em uma das peças do dramaturgo espanhol Tirso de Molina (1579-1648), na qual consta uma vívida descrição da Lisboa de sua época e um amplo destaque é dado ao movimento do porto da cidade:

\footnotetext{
donde están de todo el orbe

barcas, naves, carabelas.

Hay galeras y saetías,

tantas, que desde la tierra

parece uma gran ciudad

adonde Neptuno reina. ${ }^{87}$
} 
88. Apud Joan de Corominas (1954, v. IV, p. 166, linhas 19-22) verbete SAETÍA

89. O latim sagütta seria, nesse caso, uma latinização das formas romances já circulantes no Mediterrâneo. Ver Joam de Corominas (1954, v. IV, p. 116, linhas 1-4) verbete SAETÍA.

90. Ibidem (p. 117, linhas 22-27) verbete SAETİA.

91. Cf. Ibidem (p. 117, linhas 27-31, verbete SAETÍA.

92. Cf. Joam de Corominas (1954, v. IV, p. 116, linhas 22-23) verbete SAETA.
A saetía espanhola, assim como as formas francesa e italiana, designava um tipo bastante particularizado de embarcação à vela de grande porte, mas ainda assim capaz de navegar em alta velocidade. Portanto, reconstituir a trajetória desse étimo e entender como ele substituiu um termo excêntrico de igual sentido só é possível por meio da compreensão da história da construção naval mediterrânica. $E$, nessa investigação etimológica, é impossível não levar em conta a contribuição dos árabes, cujo peso na formação da terminologia naval portuguesa é, desde há muito, conhecido. O movimento em direção à língua árabe permite enriquecer um pouco mais o olhar contemporâneo sobre as antigas técnicas de carpintaria brasileiras. Pode-se, desse modo, relativizar o peso de escolas de pensamento que sempre enfatizaram os aspectos autóctones de nossas tradições técnicas, relembrando o quão rica foi sua proto-história mediterrânica.

Não há grandes margens para dúvidas quanto à origem árabe das formas derivadas do italiano saettia, ideia defendida pela primeira vez pelo etimólogo espanhol Eguílaz y Yanguas, ainda no século XIX88. No entanto, o aspecto diretivo da função das "seteiras" nos moinhos de rodízio levou muitos etimólogos e estudiosos da técnica a derivar as formas sétia e saetía do latim sagitta (flecha) ${ }^{89}$. Ainda que a ideia de flecha adapte-se tanto ao uso do termo na carpintaria de moinhos como na naval, a procedência árabe foi habilmente estabelecida pelo grande etimólogo Joan Corominas. $\bigcirc$ étimo original é a palavra šaitîiya, usada no árabe para designar uma grande embarcação de velas latinas comum no Mediterrâneo islâmico entre o Baixo Medievo e o início da Era Moderna.

Não foi apenas na semelhante morfologia que o etimólogo espanhol alicerçou sua interpretação, tecendo outros argumentos muito pertinentes em prol da origem árabe do nome saetía. Primeiramente, grande parte dos termos náuticos, principalmente nos idiomas ibéricos, tem a mesma procedência. E mesmo que tal termo não exista no árabe clássico, Corominas lembra-nos de que esse léxico corresponde quase inteiramente às vozes contidas no Corão. E o árabe corânico é, sobretudo, uma língua do deserto, que prescinde de quaisquer termos náuticos que não os mais genéricos ${ }^{90}$.

Ainda de acordo com Corominas, seria o caráter de embarcação veloz que estaria na origem do termo árabe šaitîya. Para o etimólogo, o sentido estaria presente na raiz š-y-t. Trata-se de um radical muito profícuo nas línguas árabes, que pode designar tanto o verbo "arder", "queimar", como "arrebatar", "ir depressa"91.

Corominas não alude ao emprego do termo saetía na carpintaria de moinhos. Ele parece conhecer apenas a forma castelhana saetín, que faz derivar, essa sim, do termo latino para "flecha"92. Contudo, sabemos que sua aplicação aos moinhos é algo tão antigo quanto o primeiro registro da palavra no espanhol. E é o nome saetia, o único empregado por Pedro Juan de Lastanosa no mais importante tratado sobre mecânica do humanismo ibérico (Los Veintiún Libros de lós Ingenios y Máquinas, publicado em 1578). O emprego de termo igual por Lastanosa está longe de ser uma evidência menor, já que seus escritos sobre as 
técnicas de moagem são considerados como "a melhor descrição do desenho e construção de moinhos que chegou a nós antes do século XVIII"93.

A evidência fornecida por Lastanosa assegura que o termo saetía já continha os dois sentidos desde a época em que foi documentado na língua espanhola. Uma distância semântica tão grande para um mesmo termo demandaria que existissem alguma similaridade entre os dois artefatos que permitisse a derivação do nome de um para o outro. Trata-se de uma hipótese que ganha força quando a trajetória documentada do termo não autoriza localizar a eventual diferenciação semântica em épocas muito remotas da história da língua.

Desse modo, o melhor caminho para tentar resolver esse enigma é buscar quais as possíveis semelhanças entre os dois artefatos que permitiriam a partilha do mesmo nome. Distanciando-se aqui da interpretação de Joan Corominas, pretende-se buscá-los não no desempenho dos objetos nomeados, mas nas técnicas pelas quais eles eram fabricados. Sai-se, desse modo, da esfera do observador externo - a única na qual a questão do desempenho sempre tende a preponderar sobre as demais - e entra-se no universo das práticas e procedimentos construtivos, no qual outros fatores estão em jogo. Assim, não é tanto o resultado final da técnica humana que deve ser o foco da busca, mas o processo pelo qual a técnica se realiza na forma de artefato. Quase como nos jogos - nos quais as regras importam tanto quanto o resultado - é preciso aqui ceder às propriedades dos materiais, às ferramentas e às performances dos corpos o espaço que thes cabe na formação da terminologia histórica das técnicas.

E a interpretação que surge dessa mudança metodológica é tão intrigante quanto esclarecedora. Assim, as formas espanholas saetía/saetín/saetilla e as portuguesas sétia/setía/seteira seriam mesmo derivadas do árabe, como afirma Corominas em exame de sua estrutura morfológica. Contudo, o seu sentido não estaria no radical $\check{s}$-y-t, mas na terminação tin - que o vocábulo espanhol saetín e o português setía, bem como o sitía do falar brasileiro souberam conservar melhor. $\bigcirc$ vocábulo tin é o termo árabe para "figo", presente também de forma ainda mais notável em at-tin, nome para a figueira. Assim, os termos românicos poderiam ecoar vozes árabes referente ao tipo da madeira e às suas técnicas de beneficiamento utilizadas na fabricação tanto da embarcação como da peça do moinho. Ao substantivo at-tin poderia ser acrescentada alguma preposição ou outro elemento não verbal ainda indeterminado94.

$\bigcirc$ termo at-tin não se refere, entretanto, à figueira mediterrânea mais comum, a Ficus carica, cuja madeira era tão pouco prestimosa que rendeu até o ditado português: "lenha de figueira, rija de fumo, fraca de madeira"95. A F. carica sempre foi uma árvore cultivada principalmente pelo seu fruto, e sua madeira só era aproveitada de maneira secundária. Tanto é que Plínio não faz menção ao uso do lenho da figueira. E em Teofrasto encontra-se outra vez um destaque maior ao seu préstimo como combustível do que para a carpintaria ${ }^{96}$.

Há, todavia, outra variedade de figueira já famosa na Antiguidade pela notável resistência e leveza de sua madeira, características que fizeram dela um
93. Cf. Zala, Javier (2000, p. 63). A extensa obra de Lastanosa, intitulada Los Veintiún Libros de lós Ingenios y Máquinas, dedica dois de seus livros à mecânica de diversos tipos de moinhos. Estudos recentes têm apontado que apesar do ostracismo ao qual foi relegado, é muito provável que tenha servido como fonte de muitas informações para o Le diverse et artificiose machines de Auguste Ramelli, obra seminal para a historiografia da técnica ocidental.

94. A existência do termo árabe شجر : التين (saj'r at-tin = árvore de figos) pode apontar alguns caminhos. Mais promissor, contudo, seria uma possível junção do nome التين com o termo شعاع (sāja = viga, trave). Não apenas a semelhança fonética seria maior, mas também indicaria a necessidade de esquadrejar os lenhos de uma árvore cujo tronco é bastante irregular e os ramos, tortuosos. São hipóteses, no entanto. Somente especialistas no idioma poderiam emitir qualquer juízo em definitivo.

95. Cf. Sebastião Almeida Oliveira (1944, p. 137).

96. Ver Theophrastus (1990, v. I, p. 453). 
97. Apesar da homonímia, o F. sycomorus não guarda relação com o sicômoro da Europa nórdica, uma espécie de plátano (Acer pseudo-platanus).

98. Cf. Pliny, the Elder. Natural history (1986, v. IV, p. 130-133).

99. Ver Alfred Lucas (2003, p. 506-507).

100. Cf. Bíblia... (Isaías, 9:10).

101. Ver Jacob Galil; Dan Eisikowitch (1968, p. 74558). recurso precioso para os carpinteiros do Mediterrâneo: o sicômoro (Ficus sycomorus $\left.\right|^{97}$. Originário provavelmente da África tropical, era cultivado desde os tempos pré-dinásticos no Antigo Egito, por onde se deu sua difusão pela costa oriental do mar interior. O grande prestígio que sua madeira gozava na Antiguidade fez com que, diferentemente da figueira, merecesse comentários elogiosos de Plínio, que assim a descreveu:

$\bigcirc$ Egito tem também muitos tipos de árvores não encontradas em outros lugares, sobretudo uma figueira consequentemente chamada de figueira egípcia. (...) A madeira dessa figueira é de um tipo singular e uma das mais uteis que há. Tão logo ela é cortada, ela é posta em um alagadiço e primeiramente afundará, mas após algum tempo começará a boiar. Demonstra-se, pois, que a umidade não the afeta, pois ela que faz afundar todas outras madeiras, drena a seiva desta. Quando ela começa a flutuar na superfície é o sinal de que a madeira está pronta para o uso ${ }^{98}$.

Como se percebe pelo relato do escritor romano, trata-se de uma madeira extremamente leve e resistente à umidade, propriedades que a tornaram um excelente material para a construção naval. E, no Egito, o sicômoro foi a principal madeira com a qual os primeiros barcos que navegaram sobre o Nilo foram construídos ${ }^{99}$. Posteriormente, com o processo de desflorestamento e a estabilização da remessa de madeiras importadas (como o cedro do Líbano e os pinhos do Egeu) o sicômoro perdeu o seu protagonismo nos estaleiros egípcios. Permaneceu, contudo, sempre às mãos dos carpinteiros locais, principalmente em períodos em que guerras ou turbulências políticas desorganizavam as redes mercantis. Além disso, o sicômoro também foi empregado na construção e, particularmente, na fabricação de sarcófagos.

Não apenas no Egito os sicômoros foram uma importante fonte de madeiras duráveis. Já nos tempos bíblicos seria ele um elemento importante no ambiente construído da Judeia. Uma passagem do Antigo Testamento ilustra bem o quanto sua madeira se fazia presente na vida na região: "Os tijolos caíram, mas construiremos com pedras lavradas; os sicômoros foram derrubados, substitui-losemos por cedros" 100

Estudos especializados demonstram que o sicômoro se tornou um recurso ainda mais importante para as sociedades do Mediterrâneo oriental após a conquista da região pelos árabes. Ao menos na região da Palestina - onde os hebreus mantiveram sempre alguma parcimônia no emprego de sua madeira e de seus frutos -, os sicômoros desempenharam ambas as tarefas muito mais intensamente para as populações árabes ali instaladas a partir do séc. VII da era cristã ${ }^{101}$.

A adoção da figueira egípcia pelos árabes deve ser compreendida, na realidade, como um pequeno, mas significativo, capítulo da absorção da riquíssima cultura helenística do Mediterrâneo pelos povos do deserto. Se as linhas gerais dessa história são bem conhecidas - principalmente nos seus reflexos no esplendor artístico e intelectual que marcou a cultura muçulmana nos séculos seguintes - suas 
linhagens mais "chãs" não receberam ainda a devida atenção. Até mesmo porque a aprendizagem das técnicas que o helenismo difundira pela região antecipou em muito o intercâmbio árabe com a cultura literária e filosófica herdada dos antigos gregos. No campo da carpintaria naval - cujas consequências tornaram-se, em longo prazo, das mais profícuas que se têm notícia na história das técnicas -, as trocas iniciaram-se tão logo as primeiras grandes cidades costeiras foram capturadas, em meados do séc. VII ${ }^{102}$. Já a grande atividade de reunião e tradução dos manuscritos gregos para o árabe só tomará verdadeiro impulso a partir da fundação de Bagdá, em 752, já sob o califado dos Abássidas ${ }^{103}$.

Longe de terem sido eles dois movimentos estranhos um ao outro, estudos recentes têm indicado que foram processos menos estanques do que se pensava. Tanto os estaleiros como as bibliotecas de mesquitas e palácios foram lugares-chave para a transmissão da cultura helenística para o mundo árabe. $\bigcirc$ principal ponto em comum, em ambos os casos, foram os agentes que intermediaram a aproximação muçulmana com a cultura mediterrânica: cristãos falantes tanto do grego como do árabe. E os cristãos (coptas no Egito, siríacos na Síria e em Bagdá) ganharam destaque nesse cenário devido à própria organização de suas comunidades ao leste, nas quais o grego permaneceria por séculos como principal idioma da cristandade.

Se nas primeiras investidas árabes ao mar a frota ainda era egípcia - e a tripulação que a conduzia se compunha por marujos alexandrinos em sua maioria -, em poucos anos, dois grandes estaleiros funcionavam no Egito. $\bigcirc$ principal era localizado na própria Alexandria e o outro, em Al-Qusayr, no Mar Vermelho ${ }^{104}$.

De especial importância foram esses estaleiros egípcios para 0 aprendizado das técnicas de construção e navegação de grandes embarcações. Foram lá também que os árabes devem ter travado o primeiro contato com a madeira do sicômoro, passando a empregá-la nas embarcações que construíam. A própria localização dos estaleiros medievais árabes parece ter tido uma relação direta com a disponibilidade de estoques florestais nas proximidades. Assim, as ribeiras egípcias tornavam-se ainda mais estratégicas, pois dispunham de acesso seguro não só aos sicômoros, mas também a outras madeiras locais, como acácias e lebeks - além de palmeiras e lótus usados para a cordoaria ${ }^{105}$.

A importância dos estaleiros egípcios só fez crescer quando o palco da expansão militar do império migrou da costa levantina para o norte da África, no final do século VII. Ao fundarem a cidade de Túnis após a destruição definitiva de Cartago, em 693, o então governador do Egito para lá mandou mais de 1000 carpinteiros de ribeira cópticos para povoarem a nova cidade e construírem cem navios de guerra para o governante local Musa lbn Nusayr. Em 704, quando já podia contar com sua frota, Ibn Nusayr iniciou a conquista do Magreb, além de uma série de investidas à Sicilia, Sardenha e Baleares. Suas campanhas culminaram, em 712, no primeiro aporte de frotas árabes na Espanha, logo após a batalha de Guadalete, marco inicial da dominação moura na Península ${ }^{106}$.
102. A precocidade - talvez se devesse falar em primazia - da carpintaria naval nessa história deveu-se à rápida criação de uma marinha árabe que atendesse às demandas da expansão militar e protegesse as redes mercantis. A tomada da Síria e do Egito, entre 639 e 642 , impôs aos conquistadores a criação de uma marinha de guerra para fazer frente às contrainvestidas do Império Bizantino, ideia implementada por Mu'âwiya quando subiu ao posto de governador do Egito, no ano de 645. Em menos de dez anos, a frota árabe foi capaz de derrotar os navios de Constantino II, na épica Batalha dos Mastros, um feito que nunca teria sido alcançado não fosse o aprendizado propiciado junto aos cristãos e semitas helenizados. Ver Hamilton Alexander Rosskeen Gibb. (1960, v. VIII, p. 808-811) verbete SAFINA.

103. Ver Franz Rosenthal (1994, p. 5-9).

104. Ver John Block Friedman e Kristen Mossler Figg (2000, p. 437-439).

105. Ainda que uma náutica mais modesta tivesse lugar no Mar da Arábia, uma costa com a qual as tribos maometanas sempre tiveram pouco contato, era certo que $\mathrm{t}$ in ha m a penas conhecimentos muito rudimentares de técnicas navais. A carpintaria naval de embarcações com cavernas era a eles desconhecida, só tendo tomado contato com esse tipo de navios de grande porte ao alcançarem $o$ Mediterrâneo. Ver Josef W. Meri (2006, p. 739-741).

106. Ver David Abulafia (2003, p.159-160). 
107. Ver March Bloch (2001, p. 136).

108. Ver Joel Serrão e Antonio Henrique Oliveira Marques (1993, p. 163).

109. O inventário de Antonio da Souza Couto (nascido na freguesia de Cernadelo, em Lousada, no norte português) traz poucos elementos que possam esclarecer algo sobre a circunscrição do termo a uma região específica de Portugal ou da península. Ainda que, atualmente, a região norte de Portugal conserve muitos termos técnicos de moinhos não encontradiços no restante do país, ainda não se dispõe de elementos que possam estender esse cenário para épocas tão recuadas da história.

110. Ver Antonio Henrique Oliveira Marques (1968, p. 194).

111. Nesse sentido é instigante notar o quanto a pronúncia portuguesa de "cortaçao" se aproximaria do latim corticeus, que significa "feito de cortiça", "feito da casca (de árvore)".
Acostumado a usar o sicômoro para obras que demandavam madeiras resistentes à "corrupção das águas", os carpinteiros acabaram por derivar a voz náutica šaitînya para designar a parte dos moinhos em que a resistência à umidade era mais premente. E mesmo que o $F$. sycomorus tenha sido uma árvore cuja presença na Península lbérica sempre foi incomum (para não dizer, excêntrica) sua madeira era de tal forma importante para a carpintaria árabe que a referência permaneceu, ainda que truncada. Os termos ainda correntes nas línguas ibéricas sétia/saetía e suas várias corruptelas seriam um testemunho do uso frequente do $F$. sycomorus pelas populações árabes. Como tão bem ensinou March Bloch, só raramente as palavras conseguem acompanhar as constantes mudanças nas coisas que nomeiam ${ }^{107}$.

A procedência árabe dos termos sétia/setía/saetía não seria um caso isolado. Ao contrário, estaria em conformidade com a maioria das antigas técnicas hidráulicas ibéricas, legadas também pelos antigos conquistadores mouros. Na verdade, é opinião compartilhada pela maioria dos historiadores que, mesmo o moinho hidráulico sendo conhecido já na época romana, sua difusão pela península só ocorreu após as invasões muçulmanas ${ }^{108}$. O clima seco e redes de drenagem insuficientes que caracterizam extensas áreas do território peninsular eram uma dificuldade incontestável. E sua superação só foi possível a partir da disseminação de sofisticadas técnicas hidráulicas introduzidas pelas propriedades agrícolas sob senhorio árabe. Não por acaso, um dos mais marcantes fatos das paisagens rurais ibéricas, o inteligente desenho de canais que conjugam campos irrigados, moinhos e jardins, só surgiu após alguns séculos de presença moura.

Resta ainda um último aspecto por esclarecer. Se os argumentos acima permitem reconstituir as tramas e agentes que relacionavam a técnica de construção de moinhos hidráulicos à carpintaria naval mediterrânica, pouco foi dito sobre o lugar do nome "siconil" nesse percurso. A própria excentricidade do termo indica o caminho a ser seguido. Não registrado em nenhum dos antigos dicionários até aqui consultados e também ignorado pela bibliografia especializada (em Portugal e no Brasil), é provável que fosse já um arcaísmo quando foi redigido em Parnaíba, no séc. XVIII09.

nome siconil seria, na verdade, um vestígio do emprego pelos artesãos medievais portugueses da nomenclatura herdada dos carpinteiros muçulmanos, que então ainda guardavam um forte apego ao léxico grego característico dos estaleiros egípcios. Dos navios construídos em Túnis, por conseguinte, não desembarcaram apenas tropas armadas e a corte de lbn Nusayr, mas também os primeiros carpinteiros árabes que traziam todo o acúmulo de técnicas aprendidas nos estaleiros de Alexandria e Qusayr.

Empregando a mesma lógica dos argumentos anteriores, existe uma forte possibilidade de que o termo cortaçao, encontrado por Oliveira Marques em um documento do século XIV, fosse o antigo nome latino para a sétia ou setía ${ }^{110}$. A palavra proviria da voz latina corticem (casca) ${ }^{111}$, cujas propriedades são similares o suficiente das da figueira, autorizando um uso análogo para as seteiras dos 
moinhos. Nesse sentido, cabe lembrar que a madeira do sobreiro era uma das mais utilizadas na carpintaria naval portuguesa. Outra hipótese é que o termo latino fosse referente a um tipo bem rudimentar de seteira - no qual a regulação da água se faz apenas na sua entrada no moinho e não no escape do esguicho, como pode ser visto nos exemplos da (Figura 22). Trata-se de uma hipótese em acordo, inclusive, com a importância da cultura árabe para a sofisticação das técnicas hidráulicas ibéricas, uma vez que vincula o surgimento de seteiras mais sofisticadas ao uso dos termos "siconil" e "setía".

No contexto brasileiro, onde a tradição de carpintaria mediterrânica foi enriquecida com algumas centenas de espécies de árvores da Mata Atlântica, a construção de uma setía obedecia aos mesmos parâmetros. Assim, foi sempre de madeiras resistentes à água, como a cabreúva, a cangerana, a canela-preta, angárajado, que eram feitas as setías dos moinhos caipiras - que contavam, via de regra, com reguladores de água na saída (Figura 23).

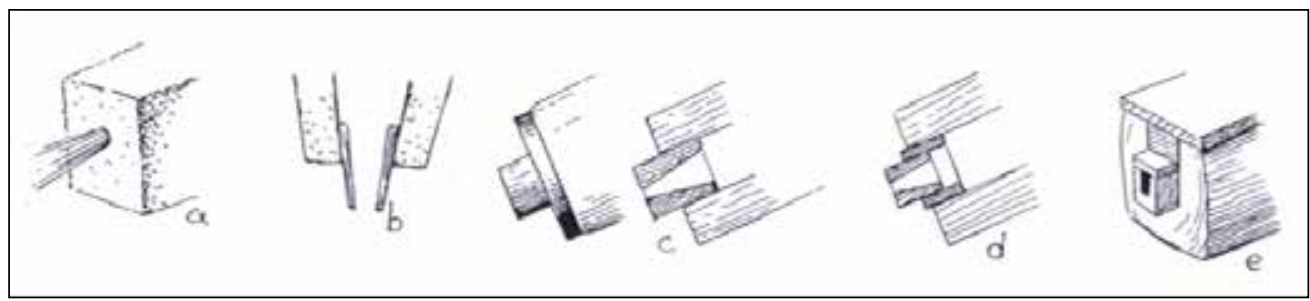

Figura 22 - Seteiras sem dispositivos de regulação da saída de água. Desenho de Fernando Galhano. Fonte: Ernesto Veiga de Oliveira; Fernando Galhano e Benjamim Pereira (1983).

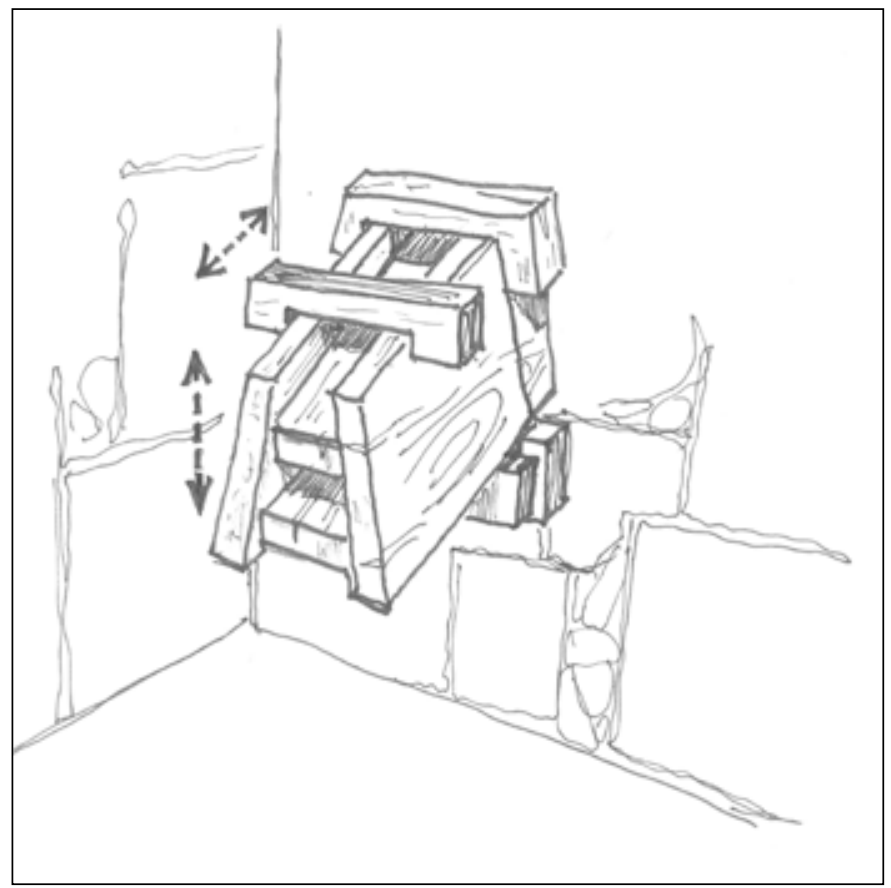

Figura 23 - Desenho de setía encontrada em moinho em Silveiras, SP. Desenho do autor. 
112. Mesmo a tratadística árabe, seja nas traduções das obras dos mecânicos alexandrinos seja em estudos de autores árabes, teria tido uma influência na cultura técnica ibérica. Foi, todavia, um fenômeno mais tardio, refletindo a intensa atividade literária própria das grandes capitais muçulmanas como Bagdá e Damasco e reforçada pela criação de bibliotecas em todos os rincões do império.

113. Ver João Leal (2000, p. 37-39 e 197-223).
A verdadeira extensão dos reflexos da terminologia técnica helenística na formação da cultura técnica ibérica ainda está para ser determinada. À primeira vista, no entanto, é crível postular que a ela logo se sobrepuseram outras correntes de saberes técnicos oriundos das mais diversas origens ${ }^{112}$. De qualquer forma, enquanto a circulação mediterrânica foi dominada pelos muçulmanos, inúmeras foram as correntes de saberes que transitavam nas mesmas carreiras mercantis e frotas militares, diversificando as bases helenísticas de sua cultura técnica. Foi como parte desse movimento de longas durações que se deu a conversão do antigo léxico grego para o idioma vernáculo.

Posteriormente, ainda que os detalhes possam nunca ser esclarecidos, da mesma dinâmica circulatória emergiram as formas romances derivadas da voz árabe šaitîya que acabaram por substituir o arcaísmo helênico siconil. A própria cronologia das formas romances de šaițîya, fornecida por Corominas, não deixa dúvidas de sua difusão a partir somente do séc. XII. Seu surgimento primeiramente em Genova vincula-o diretamente às empresas comerciais que ganham força na região do mar Adriático após as primeiras Cruzadas.

O que se procurou aqui demonstrar nessas linhas é que, no âmbito do artesanato, poucos são os anacronismos maiores do que classificar a cultura técnica dos antigos ofícios apenas por critérios apropriados aos artefatos aos quais dão origem. Assim, por mais que a classificação entre carpintaria de ribeira, carpintaria de máquinas, carpintaria de construção, marcenaria seja de grande utilidade ao historiador, seria um erro supor que presidissem mais do que superficialmente o trabalho artesanal. Os carpinteiros antigos, na realidade, teriam se guiado por critérios totalmente diferentes. Na tentativa de discernir melhor quais seriam esses critérios, poucas são as ferramentas mais valiosas que um investigador dispõe do que o estudo cuidadoso da terminologia técnica dos antigos ofícios.

No caso brasileiro, uma investigação dessas seria ainda mais profícua. Discernir-se-ia melhor, assim, como se formaram as tradições técnicas de um país cuja formação foi determinada, desde seu início, pela presença de saberes oriundos de quatro continentes diferentes. Acatados os argumentos aqui apresentados, mesmo a ideia de uma matriz portuguesa soa já um tanto inadequada, demandando ao historiador das técnicas um juízo crítico em relação aos estudos sobre o tema em Portugal - fortemente enviesados pelo salazarismo ${ }^{113}$. Assim, o que a historiografia brasileira se acostumou a referir-se como a matriz técnica lusa, seria antes parte de uma herança maior, forjada ao longo dos séculos no espaço do Mediterrâneo. Nem mesmo sua transposição para a América teria se dado exclusivamente através de colonos portugueses, incorporando agentes de diversas origens. Como pesquisas futuras podem vir a mostrar, pode não se tratar de percursos peculiares ao ofício da carpintaria de máquinas. Pelo contrário, seria uma característica comum à grande parte das técnicas que, originárias do Velho Mundo, aqui participaram da construção do território brasileiro. 
Em 1938, Luiz Saia andava às voltas com o estudo que the fora encomendado por Mário de Andrade sobre a Aldeia de Carapicuíba, um dos primeiros bens tombados pelo SPHAN em São Paulo. O relatório seria encaminhado pelo intelectual paulista a Rodrigo Mello Franco de Andrade, diretor do SPHAN no Rio de Janeiro, a fim de credenciar o jovem arquiteto ao cargo de chefe do $4^{\circ}$ distrito do serviço. $\bigcirc$ estudo sobre a Aldeia cumpriu seus objetivos: Mário de Andrade conseguiu a transferência que pleiteava ao Rio de Janeiro, e Luiz Saia tornou-se chefe do serviço em São Paulo e nos estados do sul do país.

Embora nunca tenha sido publicado, o estudo de Luiz Saia permaneceu sendo uma referência para todas as intervenções realizadas pelos técnicos da instituição ao longo dos anos. E, em 1996, durante as obras de restauro que então se realizavam no local, o arquiteto Victor Hugo Mori resolveu tirar a prova uma pequena anedota relatada no estudo de Saia referente ao cruzeiro existente no terreiro da aldeia. Em sua descrição do cruzeiro, o ex-diretor do SPHAN entremeia o relato de um dos residentes no local:

Debaixo de sua base (refeita com tijolos pelos moradores alguns anos antes da identificação do bem pelo SPHAN), informa meu amigo Vergilo, filho e morador de Carapicuíba, tem um 'segredo'. É uma pedra de moinho que foi 'do tempo dos índios'. Quando construíam a nova base de tijolos um tio do informante descobriu a pedra num lugar que existia um taquaral, enterrada no leito do riacho Carapicuíba, que passa uns duzentos metros além da aldeia. Combinaram um mutirão para trazer e enterrar aquilo ali debaixo porque 'acharam que era uma beleza'114.

Ao ser retirada a fiada de tijolos que conformava um pequeno pedestal quadrado sobre a base propriamente dita, o técnico do IPHAN ali encontrou o "segredo" dos antigos moradores, conforme o relato de Luiz Saia indicava. Tratavase mesmo de uma antiga mó de moinho, medindo mais de um metro de diâmetro e com a superfície inteiramente coberta por um padrão um tanto confuso de entalhes (Figura 24).

São hoje compreensíveis os motivos pelos quais o então diretor do SPHAN não se preocupou em conferir se o relato era verdadeiro ou não. Em uma época em que a atuação do SPHAN se caracterizava pela abordagem estetizante do restauro de bens históricos, um artefato técnico tão ordinário como uma mó não despertava mesmo grandes atenções. Mas desde sua "redescoberta" por Victor Hugo Mori, a grande mó encontra-se hoje exposta aos olhos do público, continuando a servir de base para o cruzeiro central da aldeia. E hoje, à luz do conhecimento disponível, ela é seguramente reconhecível como parte de um dos antigos moinhos de trigo do século XVII.

Identificar uma mó usada para moer o trigo não é uma tarefa difícil. As pedras fabricadas para esse fim contaram sempre com um padrão intricado de sulcos entalhado em sua superfície de contato. Como o segredo para se obter uma 
115. Um curioso exemplo de outros modos para controlar a operação da moagem foram quadrinhas rimadas de claro apelo mnemônico. Uma quadrinha desse tipo consta em um tratado norteamericano do final do séc. XVIII, que procurava guiar os ritmos de alimentação da máquina e a aberturado do vão entre as mós, que pode ser traduzida nos seguintes termos: "Se o giro é coisa larga,/ Bota mais peso e carga;/ Mas se o giro é devagar,/ Peso e carga irás baixar." No original: "If the motion be too great,/ Then add a little feed and weight; But if the motion be too slow,/ Less feed and weight will let her go." Cf. Oliver Evans (1821, p. 268).

116. O erguimento de cruzeiros sempre foi realizado no Brasil conforme uma série de preceitos e recomendações oriundos da legislação eclesiástica católica. As cruzes não só deveriam estar levantadas do chão, como deveriam ser construídas com "a perfeição e ornatos possíveis nos lugares públicos", conforme consta nas Constituições primeiras do arcebispado da Bahia. Ver Sebastião Monteiro da Vide (2010, p. 399).

117. Sobre a relação entre a triticultura colonial e o tipo de casa rural mais comum em São Paulo durante o período colonial, ver Francisco de Carvalho Dias de Andrade (2014).

118. Ver Oliver Evans (1821, p. 263). farinha de qualidade estava na eficiência na condução dos grãos do centro para a periferia das mós, cabia aos sulcos otimizar esse percurso. Ainda que grande parte do sucesso da moagem dependesse da rotação proporcionada pelo rodízio do moinho, o modo como os grãos eram, primeiramente, quebrados e depois reduzidos à farinha propriamente dita, era a tarefa própria das mós.

Mesmo os mais rústicos moinhos dispunham de alguns outros recursos para controlar a moagem, que serviam, inclusive, para fabricar farinhas dos mais diversos graus de qualidade. Um exemplo era o sistema conhecido como "alevadouro", em Portugal, e como "tempereiro", no Brasil, que permitia regular o espaço existente entre uma mó e outra (ver Figura 6). Ainda assim, eram expedientes apenas auxiliares, que nunca tiveram a mesma importância que os desenhos de sulcos nas faces das mós ${ }^{115}$.

Foi o protagonismo das mós nessa matéria que levou ao desenvolvimento, desde remotíssimos tempos, de alguns padrões de desenhos recorrentes em suas faces de contato. E, sem dúvida, foi esse singular trabalho de cantaria que despertou a admiração dos antigos moradores de Carapicuíba a ponto de the reputarem a dignidade necessária para servir de base ao cruzeiro ${ }^{116}$.

Mesmo sem compreenderem o significado histórico que tinha a mó recuperada do ribeiro Carapicuíba, é impossível não ver certo cuidado protetor na decisão de seus moradores em fazer da pedra a base do novo cruzeiro da aldeia. E ainda que se possa atribuir a seus esforços um fundo religioso sincrético (implícito no caráter secreto do ato), a velha mó mantém-se em boas condições - fato que não encontra muitos paralelos, mesmo no caso de mós pertencentes a guardiões mais qualificados.

E, com efeito, é difícil pensar em um bem cultural que tem sofrido tanto as consequências da obliteração de seus antigos sentidos. Dado serem as mós sempre feitas com rochas de incrível resistência, toda a dificuldade de sua conservação tem residido na ausência de atribuição de valor. Mesmo mós de trigo como as de Carapicuíba - que vêm ganhando importância como evidência das mais raras sobre a economia das casas bandeiristas de São Paulo - seguem ainda desprezadas por grande parte dos entusiastas do tema ${ }^{17}$. Na verdade, rara a evidência material melhor - se não de casas bandeiristas, ao menos da dinâmica econômica característica a elas - do que uma velha mó de trigo, como a que havia na antiga sede da fazenda do Jaraguá, em São Paulo, propriedade já existente desde o século XVII (Figura 25). Tendo essas questões em vista, apresentam-se abaixo algumas explicações sobre as principais características das antigas mós de trigo e suas funções na moagem do cereal.

Os padrões mais comuns para garantir um bom farinar do grão de trigo dividem a superfície da mó em oito, dez ou mais partes, semelhantes a gomos. Cada gomo, por sua vez, apresenta uma série de sulcos entalhados paralelamente ao sulco-mestre. $\bigcirc$ mesmo padrão é repetido na outra pedra do par, só que em sentido contrário. Assim, com a rotação da andadeira, os sulcos e saliências de ambas as mós operam como lâminas de uma tesoura, garantindo um fino farinar do grão de trigo em seu movimento centrífugo do olho para as bordas da mó ${ }^{118}$. 
A disposição correta dos sulcos torna-se mais decisiva conforme os grãos aproximam-se da borda da mó. Então já reduzidos a partículas muito pequenas, a força centrífuga já não atua sobre eles com a mesma intensidade, aumentando o risco de demorarem-se demais sob o peso das pedras ("engasgando" ali dentro) ou de ficarem "queimados" pela fricção excessiva119. Eram, portanto, esses problemas que o design dos sulcos procurava resolver por meio de suas muitas variações. Os moleiros também atribuíam aos sulcos o papel de facilitar a entrada de ar no interior das mós, mitigando o calor gerado pela fricção ${ }^{120}$.

Sulcos entalhados já eram utilizados antes mesmo da invenção de mós giratórias, que mantiveram e adaptaram os padrões geométricos à sua forma circular. Na realidade, cada novo modo de agenciar o emprego da força muscular, humana ou animal, nos moinhos da Antiguidade, correspondeu a uma adaptação das formas das mós e dos sulcos em suas faces. Nem mesmo a invenção dos moinhos hidráulicos conseguiu por um fim a esse desenvolvimento - ainda que a obrigatoriedade do uso de pedras redondas daí advindas tenha refreado quase totalmente o aperfeiçoamento dos desenhos.

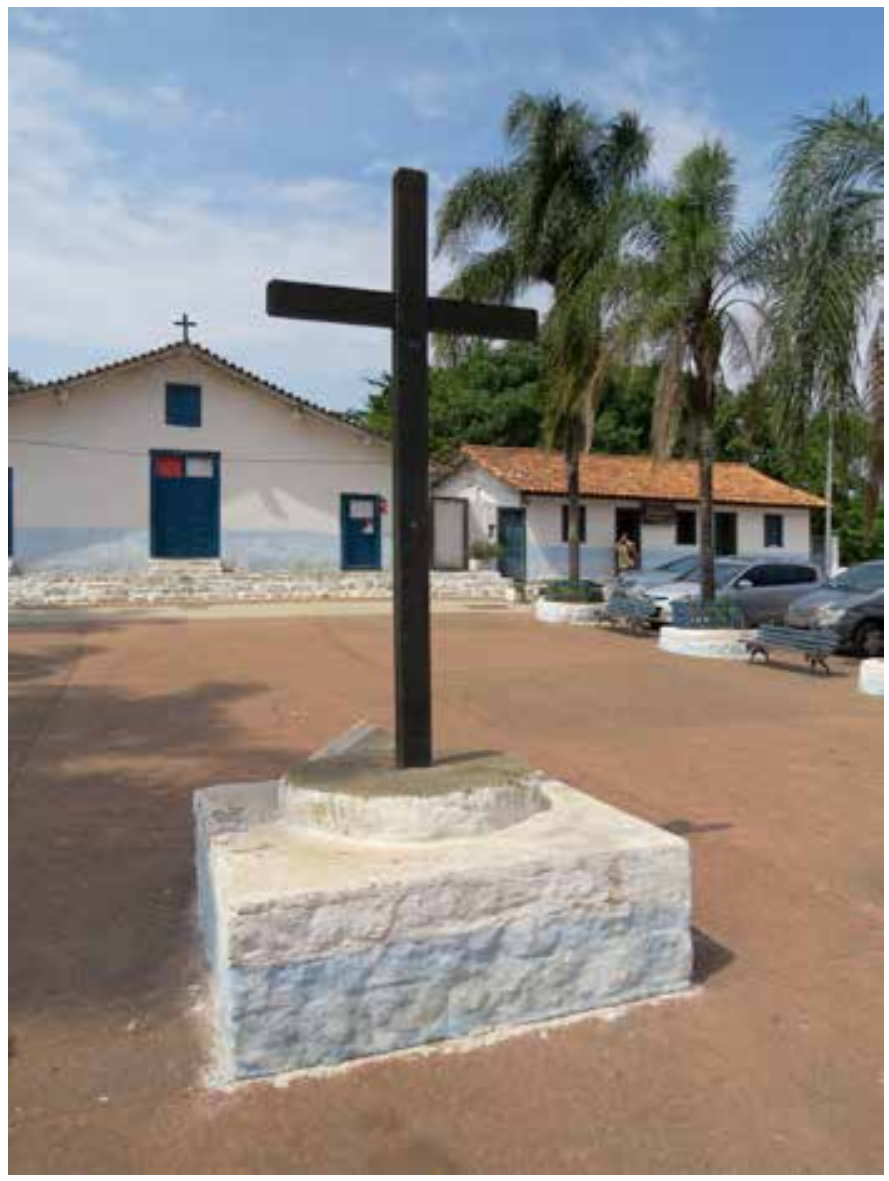

Figura 24 - Antiga mó de moinho na base do cruzeiro da Aldeia de Carapicuíba, SP. Fotografia de Fernando Siviero. 2014.
119. Ibidem (p. 260 e 261).

120. Ibidem (p. 259).

Annals of Museu Paulista. v. 23. n.1. Jan.-Jun. 2015.

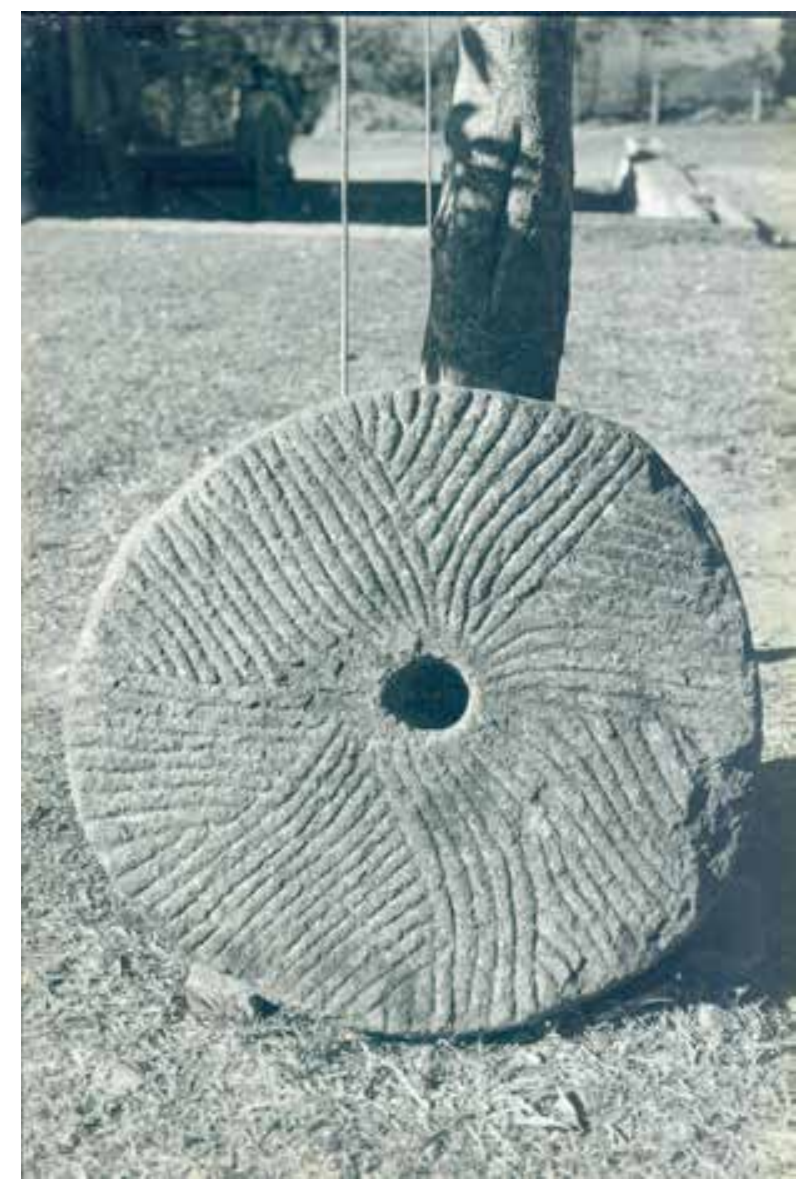

Figura 25 - Mó de trigo da antiga fazenda do Jaraguá. Germano Graeser. ca. 1940. Acervo do IPHAN-SP. 
121. A incrível estabilidade das formas das mós circulares pode ser devida mais a um intenso esforço de eficiência e padronização do que a uma difusão mais "espontânea". Os célebres moinhos romanos de Barbegal, na França, podem ter contribuído em muito para a padronização das mós dos moinhos hidráulicos. Localizados em uma região na qual abundavam rochas apropriadas para a fabricação de mós, as ruínas de Barbegal abrigavam fragmentos de mós com desenhos tão variados que justificam a hipótese de terem sediado um grande "campo de testes" para o desenho de mós, durante a Antiguidade Tardia. Ver Wayne Lorenz; Phillip Wolfram (2007, p. 62-67).
A estabilidade que se verifica nas formas das mós é tanta, que padrões surgidos na Antiguidade eram ainda usuais, mesmo que de forma secundária, nas mais diferentes partes do globo até o limiar da industrialização ${ }^{121}$. Essa estabilidade morfológica faz-se ver, por exemplo, no caso do exemplar existente no Sítio do Pe. Inácio, em Cotia (Figura 26). O pouso, ou mó de baixo, apresenta o mesmo padrão de sulcos de mós que datam do fim do Império Romano. Trata-se, de fato, de um padrão de desenho bem arcaico, surgido a partir de oito sulcos-mestres radiais que definem gomos de mesmo número, cada um deles apresentando sulcos auxiliares próprios.

Esse padrão foi perdendo cada vez mais espaço para desenhos mais sofisticados que, aumentando o número de gomos para dez, doze ou dezesseis e traçando seus sulcos em linhas espiraladas, forneciam farinhas mais aprimoradas. Mesmo assim, foram encontrados em conjunto por eras, como pode se ver no retrato de ambos os tipos nas duas ilustrações de moinhos feitas por Stradanus (Figuras 27 e 28). Trata-se de uma solução surgida durante a Idade Média, de origem holandesa ou alemã. E ainda que tenha sido o tipo mais utilizado a partir da ldade Moderna, sua difusão na Europa mediterrânica pode ter se dado mais tardiamente, conforme as mós importadas foram se fazendo ali acessíveis.

Ainda assim, foram localizados em São Paulo alguns exemplares que ostentam esse padrão, remontando eles também à época da triticultura colonial na região. O mais interessante, sem dúvida, é o que foi encontrado na Serra do Itapeti, em Mogi das Cruzes. É uma peça, provavelmente, um pouco mais recente do que as mós de Cotia, e o refinamento de seu desenho é facilmente reconhecível mesmo ao olhar pouco familiarizado com o assunto (Figura 29).

Entre um e outro modelo de desenho de mós houve, como não poderia deixar de ser, inumeráveis variáveis ao longo do tempo e do espaço. Contudo, suas linhas eram sempre definidas por regras que não se afastavam muito daquelas que regiam a confecção dos dois casos mais comuns. Configuravam essas regras verdadeiros sistemas tão engenhosos como funcionais e visavam assegurar o traçado correto do padrão. É de particular interesse notar que os dois princípios presentes em cada regra divergem um do outro. O padrão mais antigo é baseado em um sistema modular, e o outro se guia por princípios derivados da geometria dos círculos.

O primeiro sistema, claramente de acordo com o sistema modular derivado do corpo humano descrito por Vitrúvio, está implícito no desenho da mó do sítio do Padre Inácio (Prancha I). Consegue-se aferir sua aplicação na peça por meio das pequenas marcas redondas que restaram em uma das saliências contíguas a um sulco-mestre. São, ao todo, 16 marcas, às quais correspondem exatamente ao mesmo número de saliências no gomo contíguo. Tais marcações foram feitas, portanto, para auxiliar o canteiro no trabalho de refazer a picagem, tarefa que consistia em refazer o entalhe dos sulcos já gastos pelo constante atrito. Mas é possível ir além: se tomarmos a distância média entre as 16 marcações existentes e as prolongarmos em direção ao centro da mó, encontraremos exatamente o número de 20 medidas; ou 40 se considerarmos o diâmetro da circunferência 


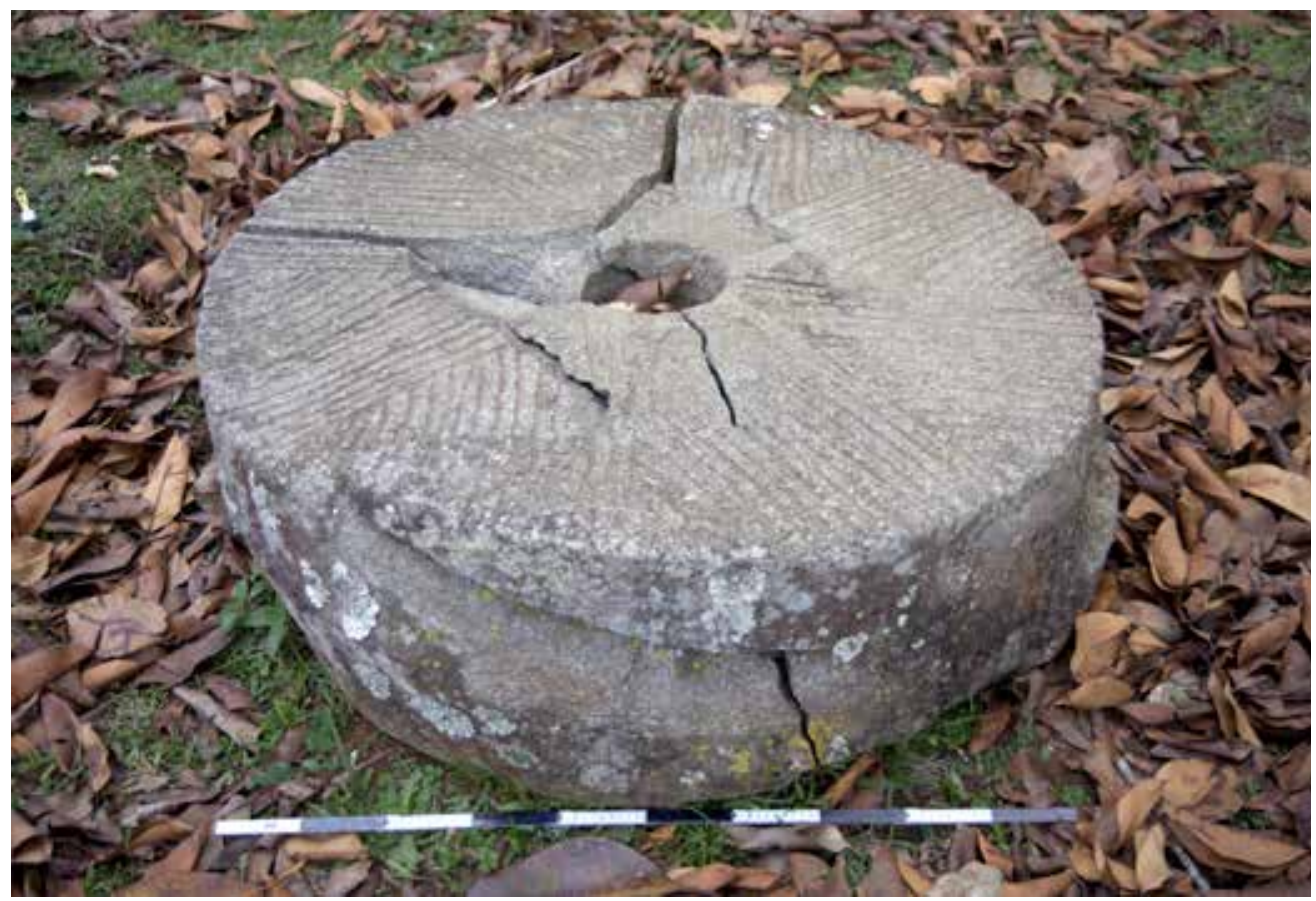

Figura 26 - Mó de baixo do Sítio do Pe. Inácio, em Cotia, SP. Fotografia de Eduardo Costa, 2011.

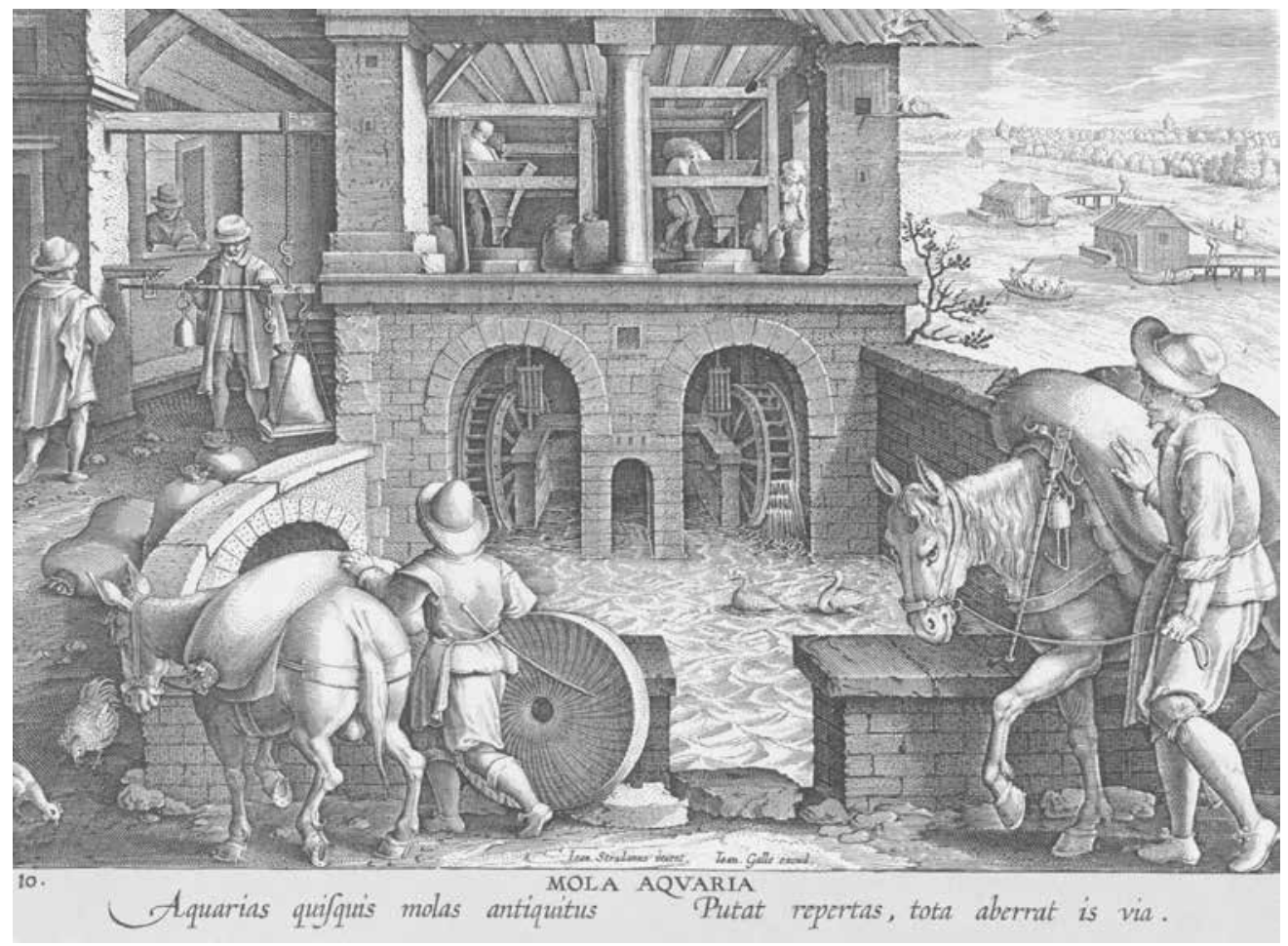

Figura 27 - Ao primeiro plano, no centro da imagem, vê-se uma grande mó com padrão de entalhes mais moderno. Jan Van der Straet (Stradanus). Mola Aquaria, gravura integrante do livro Nova Reperta, 1600. 


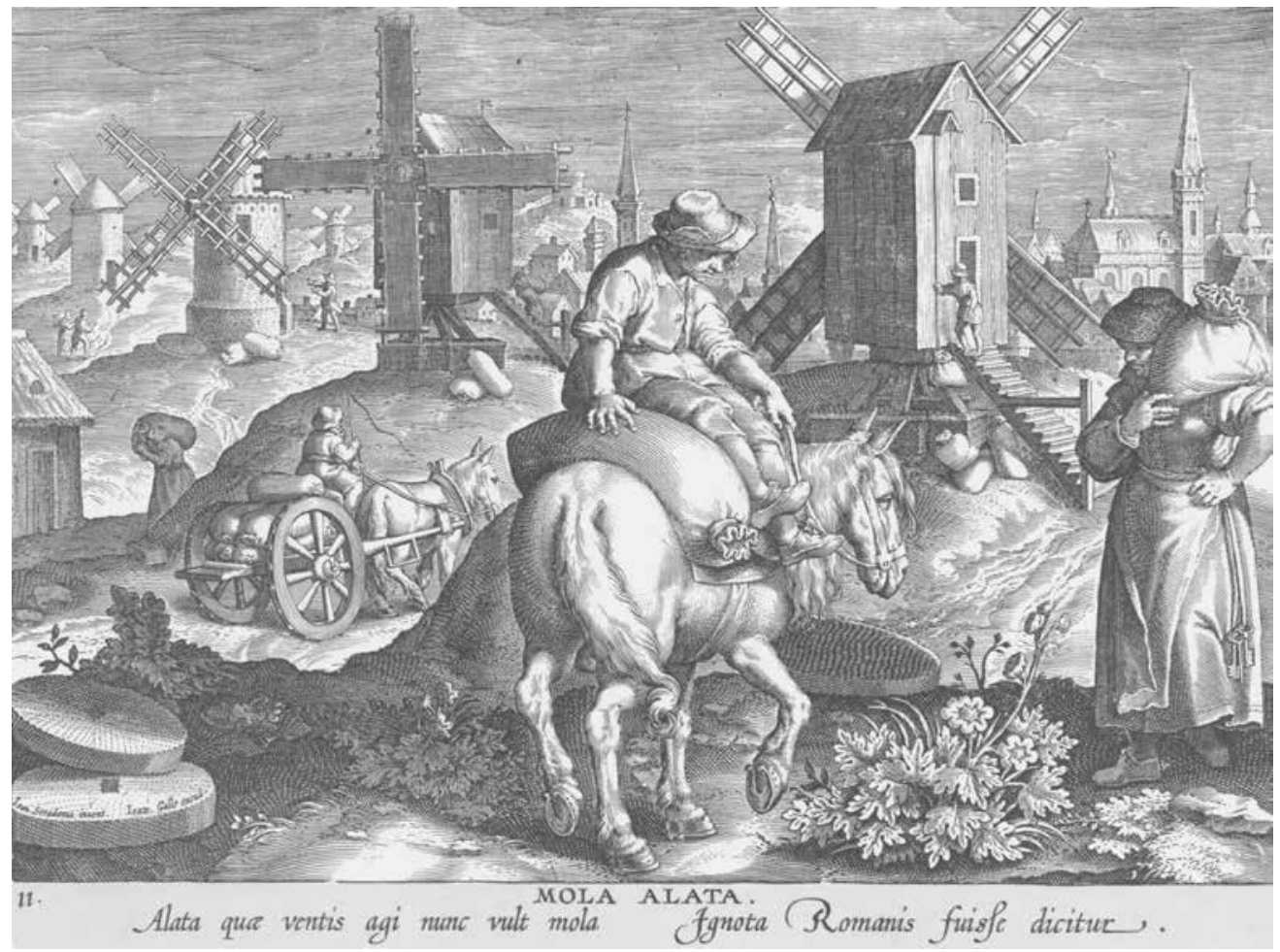

Figura 28 - No canto inferior esquerdo, vê-se duas mós ainda com o padrão romano. Jan van der Straet (Stradanus). Mola Alata, gravura integrante do livro Nova Reperta, 1600.

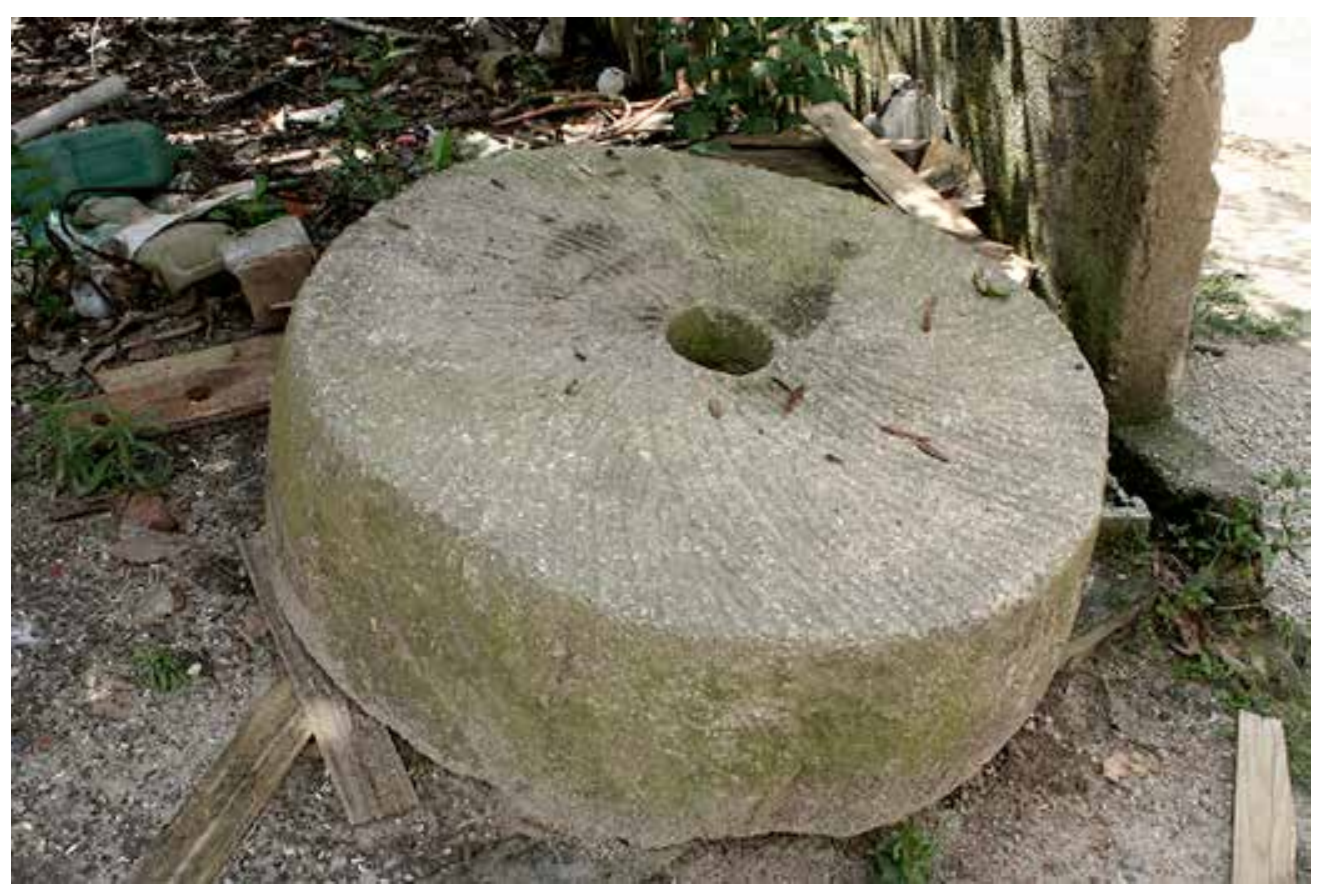

Figura 29 - Mó de moinho localizada na Serra do ltapeti, Mogi das Cruzes, SP. Fotografia de Eduardo Costa, 2009. 


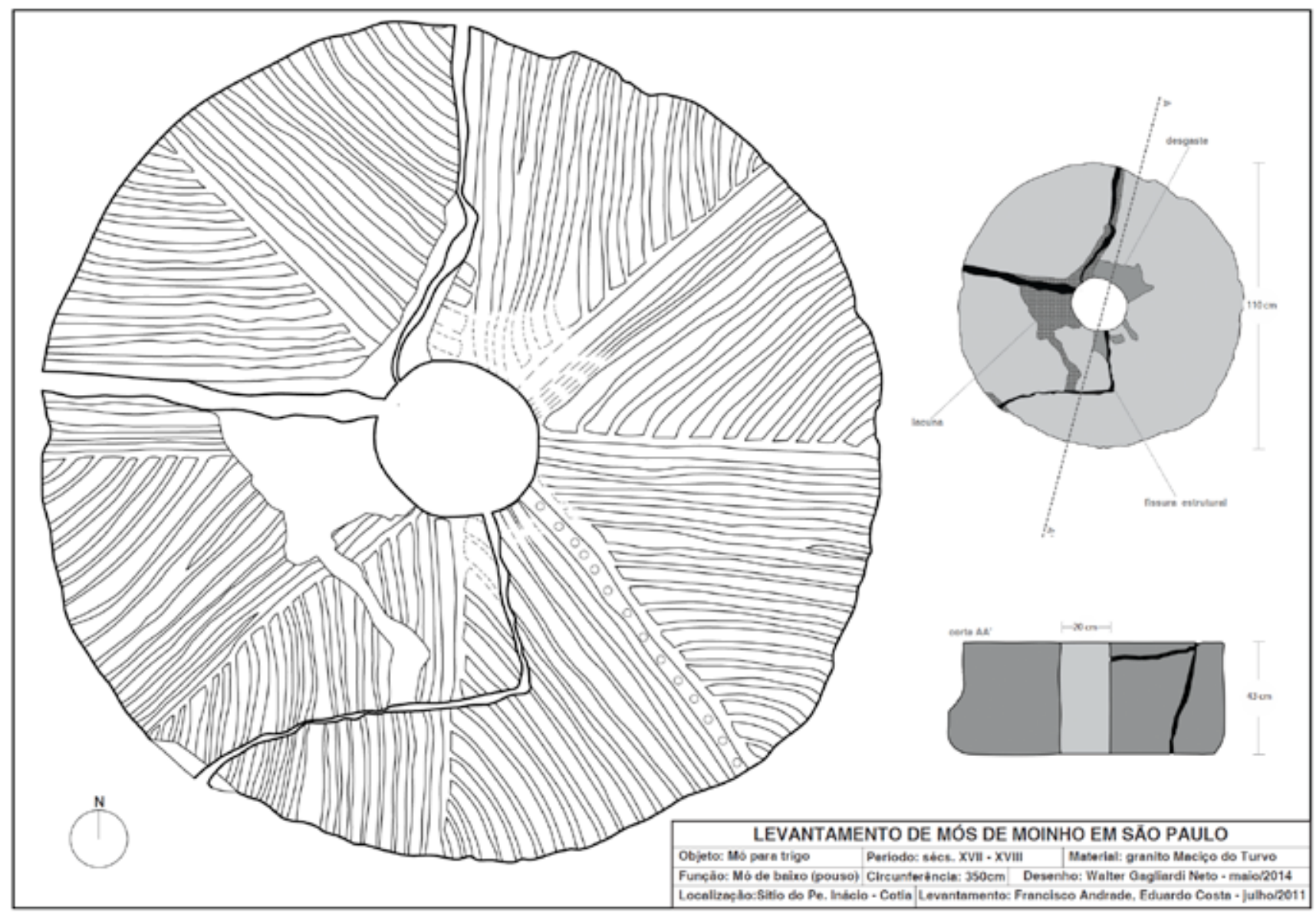

Prancha I - Mó de moinho (pouso) localizada no sítio do Padre Inácio, Cotia, SP. Desenho de Walter Gagliardi Neto (2014).

(igual a $110 \mathrm{~cm}$, ou um passo). Ou seja, a medida-base para todo o design do padrão é 2,75 cm, ou seja, a polegada.

Já o padrão mais recente aumenta o número de gomos para multiplicar a ação trituradora das "tesouras" acionadas pela rotação da mó de cima. Passa também a ter linhas curvas com vistas a compensar a diminuição da força centrífuga exercida sobre os grãos próximos às bordas das pedras - justamente onde ela é mais necessária, uma vez que os grãos já quebrados ficam menos sujeitos à sua influência. É o sistema presente nas peças localizadas na serra do ltapeti, que contavam, originalmente, com 12 gomos.

As diferenças presentes nesse desenho foram introduzidas para que se obtivessem os melhores ângulos de curvatura das linhas. E lançavam mão de pequenas circunferências riscadas à giz a partir do olho da mó para determinar os ângulos mais apropriados conforme cada caso. A erudição presente nesse sistema era tanta que a difusão de mós com sulcos em espiral deu margem para o aparecimento, nos tratados técnicos sobre moagem, de capítulos inteiros dedicados apenas às mós e ao melhor modo de desenhar seus sulcos ${ }^{122}$.
122. Dadas às complexidades das operações e as inúmeras variáveis que deveriam ser levadas em conta, é duvidoso que tais tratados conseguissem transmitir com exatidão regras que assegurassem uma moagem de boa qualidade. Para as regras por trás do traçado espiralado dos sulcos, ver Oliver Evans (1821, p. 260264). 
123. A discrepância entre as alturas do pouso e da andadeira já era um fato antigo em Portugal, onde um documento de 1358 descreve pares de mós de alturas diferentes. Em mais um aspecto as mós de trigo de São Paulo assemelham-se às suas congêneres portuguesas: ambas nunca excederam os 120 centímetros de diâmetro. Diferentemente de outros países europeus onde os maiores moinhos podiam ter mós de 2 metros de diâmetro, em Portugal mesmo os maiores moinhos nunca dispuseram de pedras desse porte.

124. Em inventários do séc. XVII, há menções a jogos de mós com "grandes faltas" advindas de desgaste $\mathrm{e}$ pancadas. No inventário de Manuel João Branco, um jogo novo de mós foi avaliado com preço menor por ter a pedra "de cima faltas grandes que para se endireitar se lhe hão de botar fora três dedos de pedra pouco mais ou menos". Inventários... (1921, XIII, p. 306-307).

125. Ver Ernesto Veiga de Oliveira; Fernando Galhano e Benjamim Pereira (1983, p. 359).

126. Ibidem (p. 358).
As diferenças entre os dois tipos não ficavam apenas no modelo de desenho que apresentavam. O maior esmero presente no entalhe dos sulcos da mó da serra do Itapeti (Prancha II) também é um indicativo de seu melhor desempenho na moagem, em comparação com as mós de Cotia. Nesse último caso, a distância existente entre um sulco e outro fica, na média, entre 1,5 e 3 centímetros, enquanto na mó do ltapeti tal distância fica sempre entre 1,5 e $2 \mathrm{~cm}$. Mesmo sendo uma diferença muito pequena, a existência de uma folga por demais espaçada entre um sulco e outro era a principal causa de um farinar grosseiro.

Não apenas nos desenhos dos sulcos que as mós de trigo coloniais se filiam às suas matrizes europeias. A diferença de tamanho entre 0 pouso e a andadeira também se verifica nos casos em que se preservaram ambas as peças do par. No caso do sítio do Pe. Inácio, a andadeira mede $14 \mathrm{~cm}$ de altura e seu pouso, $43 \mathrm{~cm}$. Nas mós da serra do Itapeti, o pouso tem $40 \mathrm{~cm}$ de altura, ao passo que andadeira tem exatamente a metade. $\bigcirc$ porte exagerado dos pousos em relação às andadeiras justifica-se pela necessidade de fixidez exigida para uma melhor rotação da mó de cima, sem que se corra o risco de fraturar a pedra ${ }^{123}$. No tocante ao diâmetro de ambas as peças, os dois pousos apresentam medidas ligeiramente maiores que as mós de cima. A discrepância, contudo, seria resultado de reparos feitos após fraturas nas andadeiras, já que pancadas oriundas do mau balanceamento das mós faziam parte das rotinas dos moinhos de qualquer espécie ${ }^{124}$.

Principalmente em função do desgaste do padrão de sulcos, impunha-se, que periodicamente, as estrias fossem refeitas para garantir um farinar mais fino. A refeitura dos entalhes era sempre feita utilizando-se ferramentas como picões e picadeiras, motivo pelo qual tal tarefa foi sempre chamada de repicagem das mós. O intervalo entre uma picagem e outra variava de acordo com o volume do trabalho de cada moinho. Nos moinhos menores, principalmente de uso comunal de pequenas aldeias, muitas vezes, a repicagem era feita apenas uma ou duas vezes por ano ${ }^{125}$. Mas nas zonas mais densamente povoadas, a periodicidade da repicagem chegava a ser definida nos regimentos dos ofícios redigidos pelos conselhos municipais ${ }^{126}$. Era normalmente incumbência dos próprios moleiros, mas a figura do andarilho que ia de uma paragem para outra oferecendo seus serviços de repicagem chegou a ser comum em alguns países da Europa.

Já no caso de São Paulo, durante o período colonial, nada se conhece de documentação a respeito. Todas as afirmações partem dos poucos exemplares já identificados de velhas mós em antigas localidades triticultoras da ex-capitania vicentina. Mas o exame atento de algumas peças ajuda a esclarecer alguns aspectos dessas rotinas da operação de grandes moinhos de trigo.

Nos casos em que se dispõe das duas peças do par, verifica-se que apenas os pousos permaneceram fiéis às regras do traçado dos sulcos. As andadeiras apresentam certo "desleixo" para com os princípios estipulados inicialmente. É algo que se verifica facilmente no caso da andadeira do Padre Inácio, na qual se perde totalmente o simples padrão romano adotado por seu par (Prancha III). Mesmo as mós da serra do Itapeti apresentam indícios, ainda que 


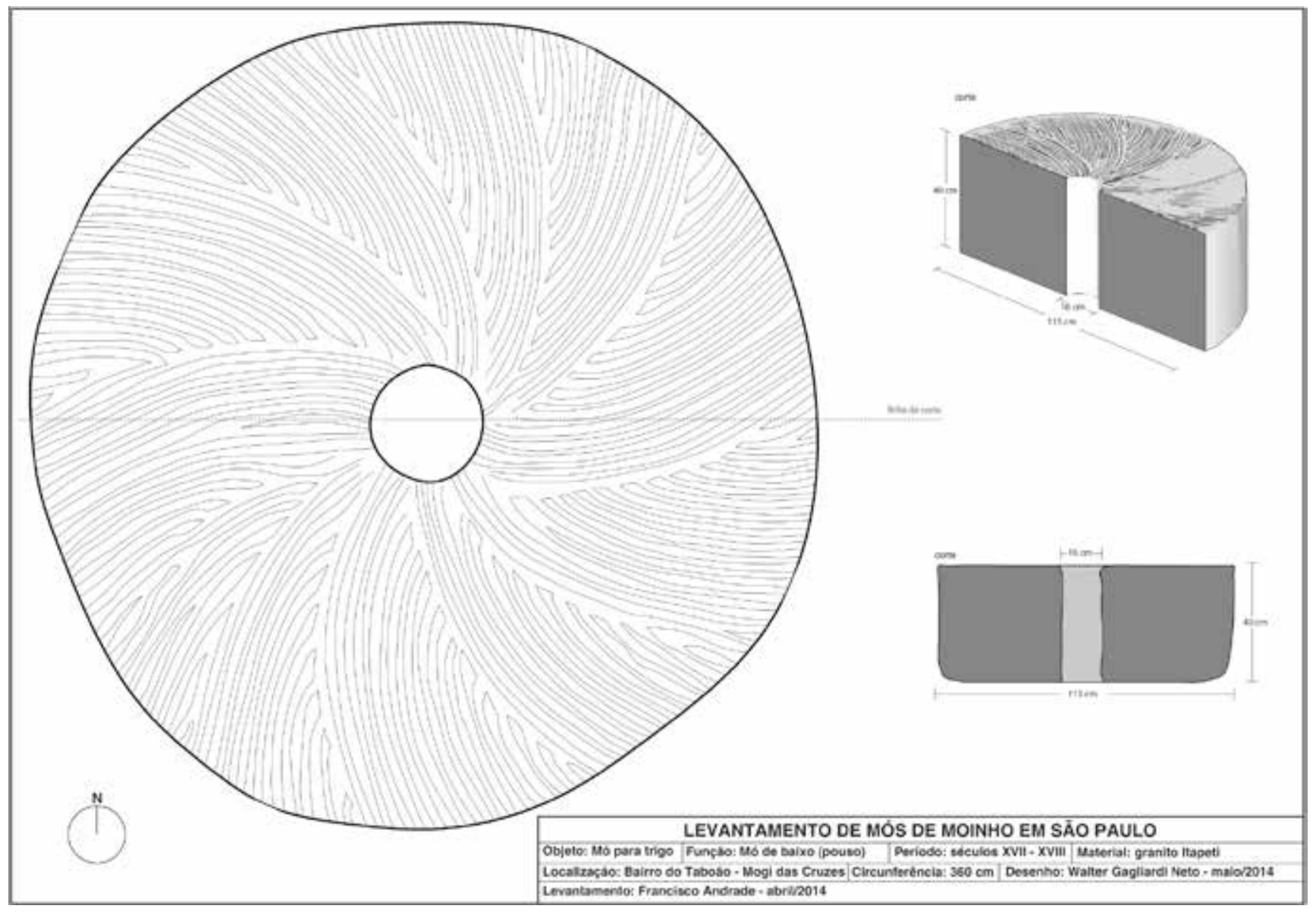

Prancha II - Mó de moinho (pouso) localizada na Serra do Itapeti, Mogi das Cruzes, SP. Desenho de Walter Gagliardi Neto (2014).

mais discretos, de dificuldade em seguir os padrões iniciais. Mesmo que a andadeira novamente apresente as maiores discrepâncias (Prancha IV), nota-se que as porções oés-sudoeste e leste do pouso apresentavam anteriormente mais gomos, toscamente rearranjados em número menor após uma repicagem (ver Prancha II).

Ainda assim, as discrepâncias verificadas nos exemplares acima descritos não se comparam com o completo desarranjo dos sulcos da mó que serve de base para o cruzeiro de Carapicuíba. Mesmo quando comparada à andadeira do sítio do Pe. Inácio, a mó de Carapicuíba surpreende pela aparente falta de qualquer padrão no tracejado de seus sulcos. Nesse caso, além da direção das linhas aparentemente definida a esmo, chama a atenção as interrupções e quebras abruptas de seu traçado, como pode ser visto na sua elevação (Figura 30).

$\bigcirc$ que uma análise mais cuidadosa demonstrou, no entanto, é que tais quebras são vestígios de repicagens anteriores. Ao procurar recompor os padrões mais antigos, foi possível identificar dois padrões bem distintos. Conforme se vê na (Figura 31 ), um dos padrões se aproximaria do das mós do ltapeti (em laranja), já o outro (em verde) parece seguir desenho semelhante ao da mó do sítio do Padre Inácio. 


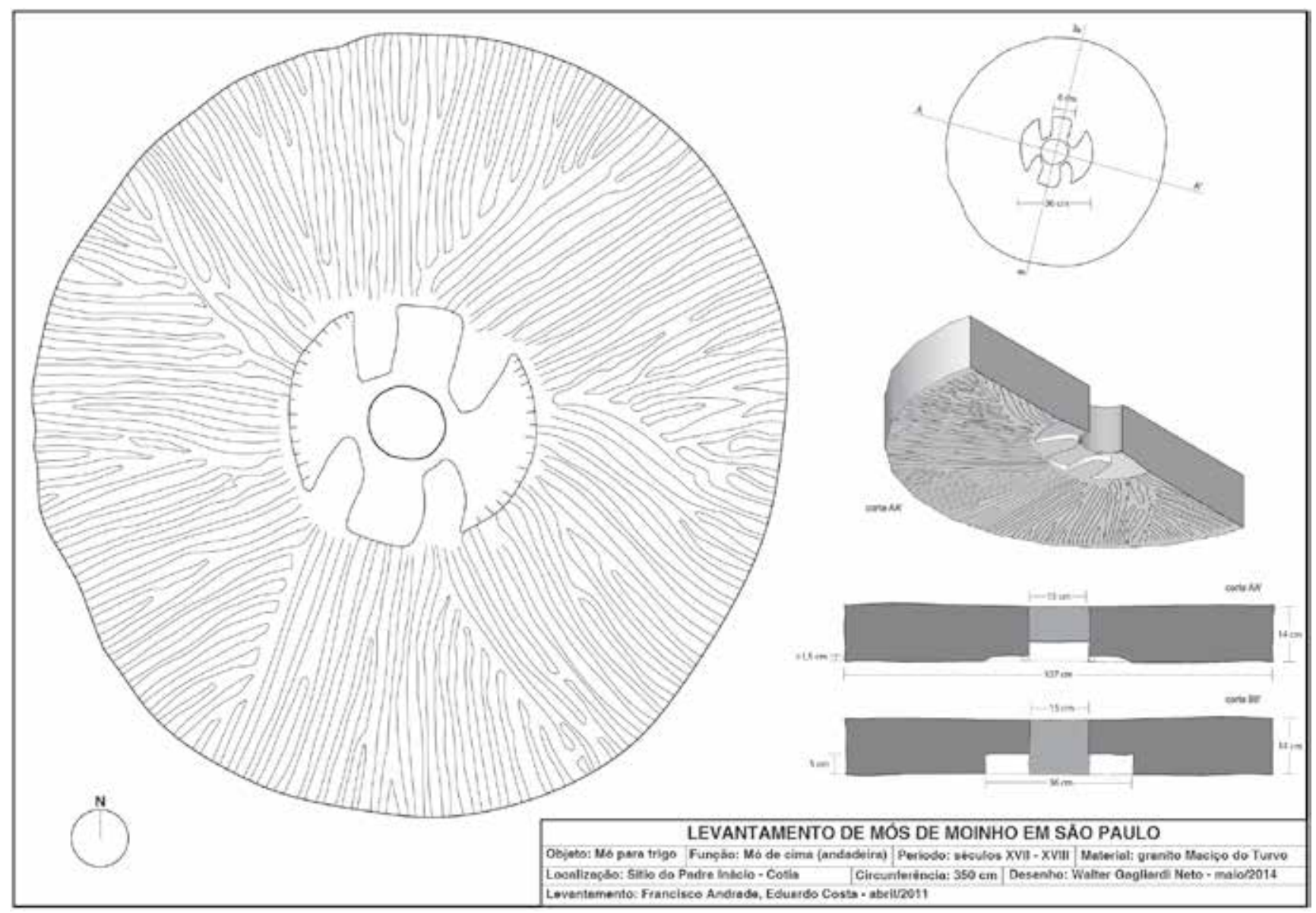

Prancha III - Mó de moinho (andadeira) localizada no sítio do Padre Inácio, Cotia, SP. Desenho de Walter Gagliardi Neto (2014).

127. A busca por rochas duráveis, capazes de suportar os esforços próprios aos trabalhos de moagem, fez-se ver desde os mais remotos tempos. $\mathrm{E}$ no tempo de Plínio, o Velho, as mós eram já quase sinônimo de rochas resistentes, conforme se vê em uma das passagens da História natural: "Nenhuma outra pedra é mais durável do que as de mós; pois, como também se vê em relação às madeiras, é característico de pedras de outros tipos serem incapazes de suportar chuva, sol ou o rigor do inverno". Ver Pliny, the Elder (1986, v. X, p. 108111). Conforme a moagem foi se sofisticando, a importância de dispor de mós de boa qualidade quadro que surge daí é dos mais interessantes, pois se percebe que as bruscas interrupções das linhas e sua direção quase errática são, na verdade, uma acomodação aos padrões anteriores, conforme o exercício de sobreposição dos três padrões demonstra (Figura 32). Esquecidas as regras que guiavam a ordenação dos sulcos, pouco restava ao artífice - certamente um índio ou mameluco ali morador - senão tentar se adequar aos traçados cujos vestígios pôde distinguir na superfície já gasta da peça que então trabalhava.

Diante dessas evidências é tentador atribuir às mós coloniais de São Paulo uma origem metropolitana e enxergar no paulatino desarranjo de seus desenhos a incapacidade da mão de obra local em reproduzir a geometria europeia. Tal afirmação estaria de acordo tanto com a velha tese sobre a penúria técnica da colônia como também com o regime de grande especialização que caracterizou o fabrico de mós na Europa desde a Antiguidade ${ }^{127}$. $O$ postulado não encontraria, contudo, qualquer evidência sobre a qual pudesse se sustentar. Pois todas as mós de trigo identificadas até agora em São Paulo foram fabricadas com granitos comuns nos locais onde atualmente se encontram, conforme confirmam os breves exames de 


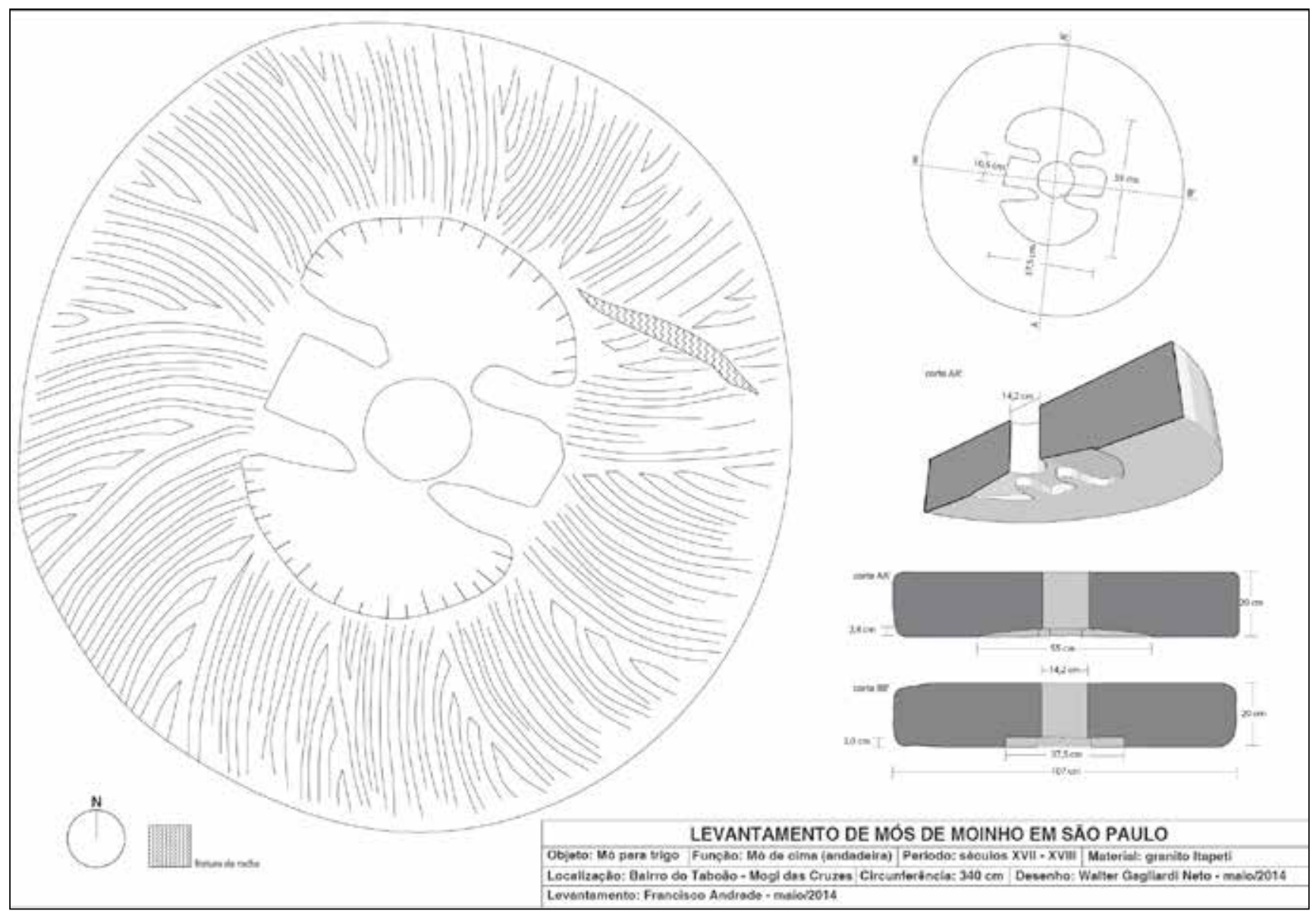

Prancha IV - Mó de moinho (andadeira) localizada na Serra do ltapeti, Mogi das Cruzes, SP. Desenho de Walter Gagliardi Neto (2014).

suas constituições geológicas que se pôde realizar ${ }^{128}$. Desse modo, tais pedras são mais uma evidência do elevado nível técnico que possibilitou o surgimento de uma agricultura comercial no planalto paulista durante o século XVII. Somente com a derrocada final da triticultura na região, a partir do último quartel dos Seiscentos, é que os saberes técnicos envolvidos nas mais sofisticadas operações da moagem foram se desorganizando, conforme pode ser visto no exemplo da mó de Carapicuíba.

No âmbito da especialização no fabrico de mós, toda a Europa conheceu a divisão existente entre pedras destinadas a moagem do trigo e aquelas voltadas para a moagem de cereais de importância secundária na alimentação humana. Em Portugal, esses diferentes usos fizeram notória a divisão entre "mós alveiras" e "mós secundeiras"129. As "mós alveiras" só produziam farinhas de trigo alvas, sendo as únicas que chegavam a ser importadas de outros países, usualmente, da França. Já as "mós secundeiras" eram utilizadas apenas para moerem o centeio, a aveia ou o milho-miúdo. Eram também chamadas de "barroqueiras", por serem feitas de pedras granulosas, ou "barrocas" e eram feitas exclusivamente de pedras locais, principalmente do granito tão abundante no norte do país ${ }^{130}$. reforçou ainda mais a especialização dessa indústria. Algumas regiões que dispunham de jazidas apropriadas e boas condições de transporte logo dominaram o mercado da grande moagem, exportando suas mós por distâncias relativamente longas. Entre as regiões exportadoras, cabe destacar algumas cidades da Holanda, a região de Colônia, na Alemanha e, sobretudo, a região de Fertesous-Jouarre, nas proximidades de Paris. Estudos recentes têm demonstrado que a aquisição ou encomenda de um par de mós chegava a somar $1 / 3$ do custo de construção de um moinho. $\mathrm{O}$ alto investimento faz-se 


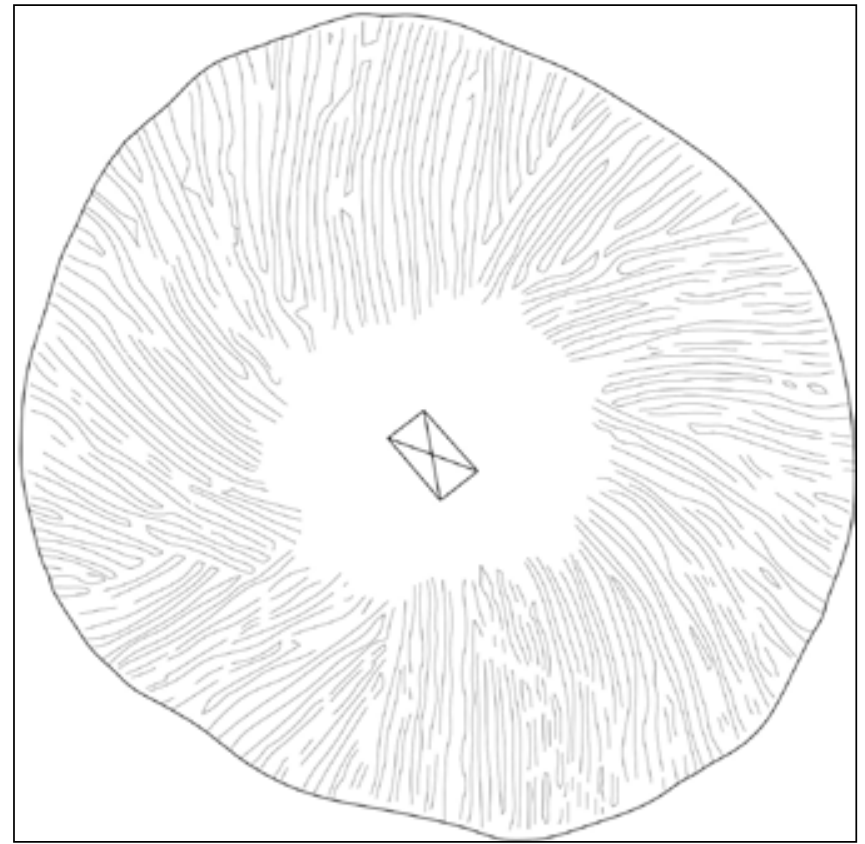

Figura 30 - Elevação do padrão de sulcos da mó da Aldeia de Carapicuíba. Desenho de Walter Gagliardi Neto, 2014.

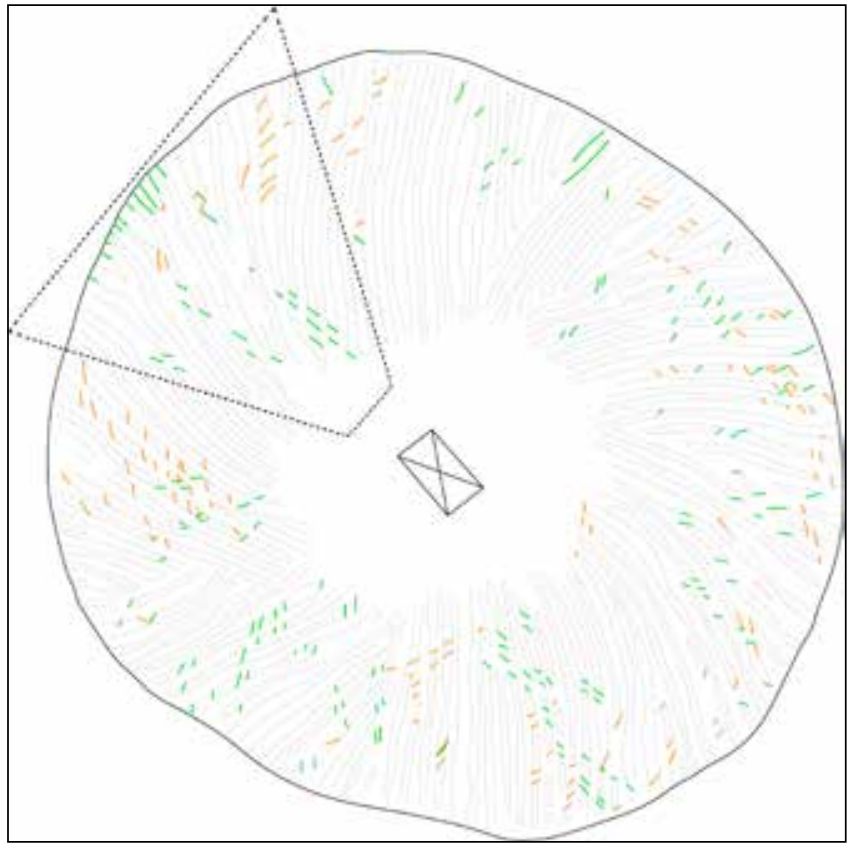

Figura 31 - Elevação da mó de Carapicuíba com a reconstituição de picagens anteriores com outros padrões de sulcos. Desenho de Walter Gagliardi Neto, 2014.

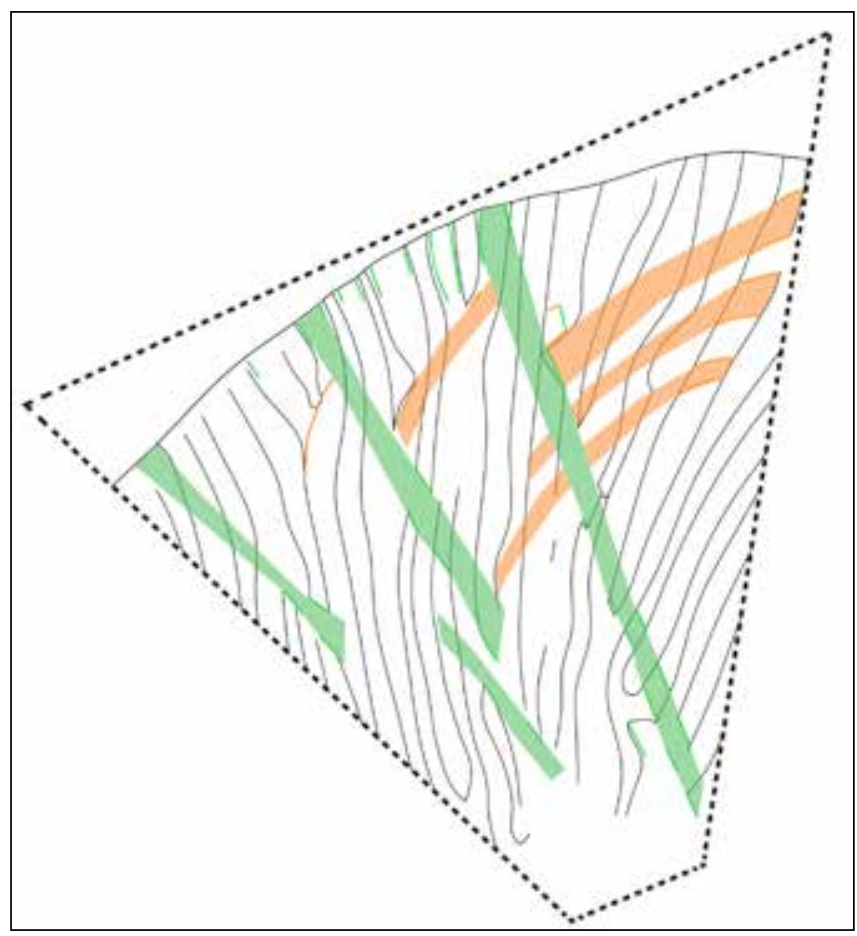

Figura 32 - Detalhe de parte da mó de Carapicuíba, SP, em que se evidencia acomodação do padrão atual a padrões mais antigos. Desenho de Walter Gagliardi Neto, 2014. 
As "mós secundeiras" portuguesas tem uma importância ainda maior para a classificação das técnicas de moagem brasileiras, pois todas as mós utilizadas nos moinhos de fubá aqui existentes foram um desenvolvimento das mós europeias de cereais secundários. Quando o milho americano passou a ser beneficiado em moinhos hidráulicos, adaptou-se o padrão de mós secundeiras para esse uso. Assim, em conformidade com suas congêneres portuguesas, as mós para milho apresentam apenas alguns poucos sulcos ou mesmo não exibem sulco algum. Em contrapartida, ostentam, em suas superfícies pequenas, rasas cavidades apenas picotadas pelo uso do picão ou do ponteiro ${ }^{131}$.

extenso território no qual as mós de milho são encontradas no Brasil faz com que qualquer tentativa de as caracterizar esbarre em dificuldades enormes. De maneira oposta ao caso das raras mós de trigo paulistas, sua recorrência através de ampla zona do território nacional dificulta qualquer avaliação mais firmemente alicerçada. Mesmo sabendo que ainda é preciso a reunião de levantamentos ainda por serem feitos tanto em São Paulo como em outros estados, dois breves comentários podem ser feitos sobre o assunto.

Primeiramente, parece ter existido uma relação direta entre o número de sulcos existentes nas mós de moinhos de milho e o tamanho da demanda a que eles precisavam atender. Tal relação foi primeiramente conhecida a partir do depoimento de um canteiro que ainda fabricava mós por encomenda na cidade de Boa Esperança, em Minas Gerais. Durante suas explicações sobre as técnicas que aplicava no fabrico de mós, o canteiro, que desconhecia os padrões usados na moagem do trigo, discordou da regra de talhar muitos sulcos na face das pedras, ainda mais muito próximos uns dos outros. Mós com muitos sulcos não seriam capazes de produzir bom fubá, já que quanto mais sulcos tiverem, mais rapidamente os grãos de milho serão expelidos de seu interior. Ao aumentar a quantidade de "canjiqueiras" - como são chamados os sulcos em Minas Gerais -, o fubá ficaria muito grosso. Seria, portanto, um fubá pouco saboroso, cujo aspecto grosseiro seria o completo oposto do fubá "mimoso", como é carinhosamente nomeado o fubá mais fino na fala caipira.

As explicações fornecidas pelo canteiro de Boa Esperança ajudam a explicar uma característica de mós de milho de origem mais antiga. Diferentemente das pedras dos moinhos caipiras mais recentes, que costumam apresentar entre três e quatro sulcos em suas faces (ou mesmo não apresentam sulco algum), mós mais antigas tendem a ter mais sulcos. Embora seja tarefa das mais difíceis datar uma mó de milho antiga com precisão, são sempre peças com muitos sulcos que se encontram nas antigas fazendas paulistas do século XIX.

É possível que a discrepância existente entre o número de sulcos das mós oitocentistas e o das dos moinhos caipiras atuais possa ser explicada a partir dos parâmetros fornecidos pelo canteiro mineiro. Mós com muitos sulcos fornecem um fubá grosseiro, mas aumentam a capacidade operatória dos moinhos - à custa da qualidade do produto obtido. Se esse é um ônus que os pequenos sitiantes não parecem ter precisado suportar, o mesmo não pode ser dito sobre o universo alimentar nas grandes fazendas paulistas do século XIX. ainda mais compreensível quando se considera que um grande moinho podia inutilizar um par de mós de baixa qualidade em um ou dois anos de uso. Ver John Langdon (2004, p. 162-175).

128. Em consulta a bibliografia especializada disponível, encontraram-se inúmeras semelhanças entre os aspectos visíveis nos granitos utilizados $\mathrm{e}$ as formações rochosas mais comuns na região em questão. No caso das mós do Sítio do Pe. Inácio, elas são em tudo semelhantes ao granito Maciço do Turvo. Ver Yociteru Hasui (1975, p. 169). Já as mós da serra do Itapeti são feitas de um granito muito semelhante ao da descrição efetuada para o granito Itapeti. Ver Adriana Alves (2009, 29-30). O granito utilizado na mó de Carapicuíba é muito semelhante ao granito Pirituba, característico do entorno da cidade de São Paulo e largamente empregado nas obras da capital a partir da primeira década do século XX.

129. Essa diferenciação também é referida no mesmo documento português de 1358 citado por Oliveira Marques, no qual há menção a "mós trigueiras" e "mós segundeiras". Cf. Antonio Henrique Oliveira Marques (1968, p. 194).

130. Ver Ernesto Veiga de Oliveira; Fernando Galhano e Benjamim Pereira (1983, p. 364).

131. O aspecto irregular que a superfície da mó adquire ao ser lavrada com o picão tornou comum em certas regiões portuguesas o uso da designação mó barroqueira, com o sentido de "granulosa", "porosa" "piçarrenta". 
132. O tamanho diminuto da mó confirma a sua origem no século XIX, já que há uma correspondência direta, nos moinhos horizontais, entre o tamanho da mó e o tamanho do rodízio. Como a fazenda Pirahy encontrase em um incomum e amplo terraço existente às margens do córrego de mesmo nome, um moinho de grande porte não encontraria ali uma implantação adequada. Somente com a invenção de geradores elétricos ou de motores a diesel, essas limitações topográficas foram superadas, época em que a fazenda começou a dispor de pedras maiores. Assim é quase certo atribuir a essa pequena mó uma origem oitocentista.
No apogeu das grandes lavouras oitocentistas em São Paulo, havia um número elevado de escravos cuja alimentação diária era baseada no fubá. Não é de se surpreender, desse modo, que as maiores fazendas dispusessem de moinhos cujas mós com até 15 sulcos em suas faces forneciam uma solução fácil para atender a grande demanda alimentar do plantel de escravos. Portanto, somente mós mais recentes, fabricadas já no século passado - em um contexto de forte urbanização - tendem a apresentar poucos ou nenhum sulco. Já não havia então uma demanda tão grande de milho a ser beneficiado nas zonas rurais, e os pequenos sitiantes podiam se dar ao luxo de produzir um fubá de melhor qualidade em seus moinhos.

Essa é uma discrepância que pode ser claramente percebida ao se comparar duas mós similares em material e porte, mas fabricadas em épocas distintas. Uma mó feita de granito-rosa, com cerca de $50 \mathrm{~cm}$, faz parte do acervo da fazenda Pirahy, uma das mais antigas fazendas de açúcar existentes em ltu (Figura 33). Trata-se, certamente, de uma mó do século XIX, época em que a fazenda ainda mantinha seu destaque econômico ${ }^{132}$. Com a grande demanda que haveria ali, foi preciso recorrer a um alto número de sulcos na pequena área de sua face para dar conta de processar todos os grãos de milho necessários.

Muito distinta, quase de maneira oposta, é uma mó também de granitorosa encontrada na zona rural de Paraibuna, no Vale do Paraíba. A presença ali de uma mó de granito-rosa, rocha típica da região de ltu, indica que foi levada em meados do século XX, quando caminhões e carretas já transportavam os produtos das oficinas de cantaria existentes em Salto para áreas ainda mais distantes. Medindo $60 \mathrm{~cm}$ de diâmetro, a mó apresenta apenas três "canjiqueiras", o que confirma os princípios aqui apontados (Figura 34).

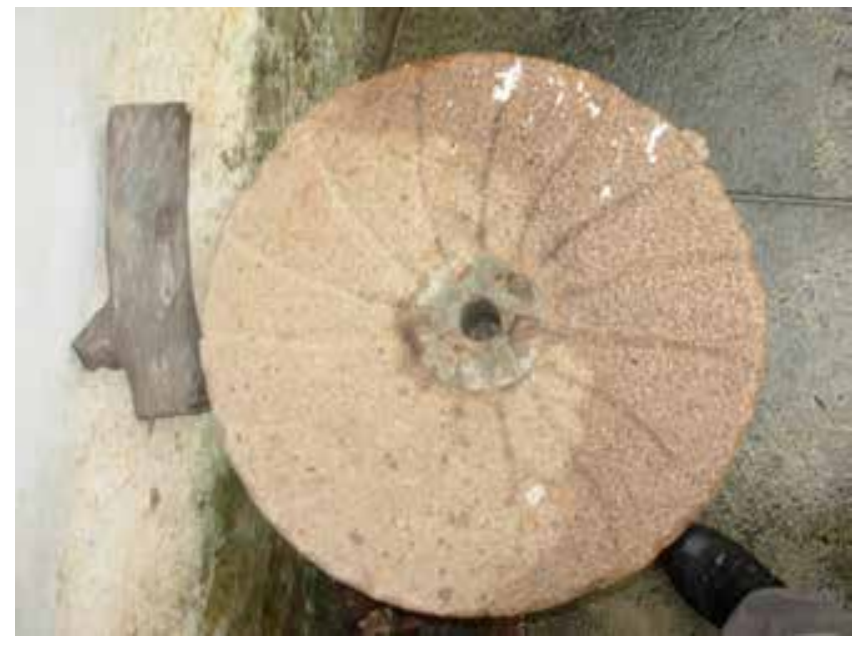

Figura 33 - Pequena mó da Fazenda Pirahy, em ltu, SP. A mó mede cerca de $50 \mathrm{~cm}$ de comprimento, mas apresenta 15 sulcos. Fotografia do autor, 2012.

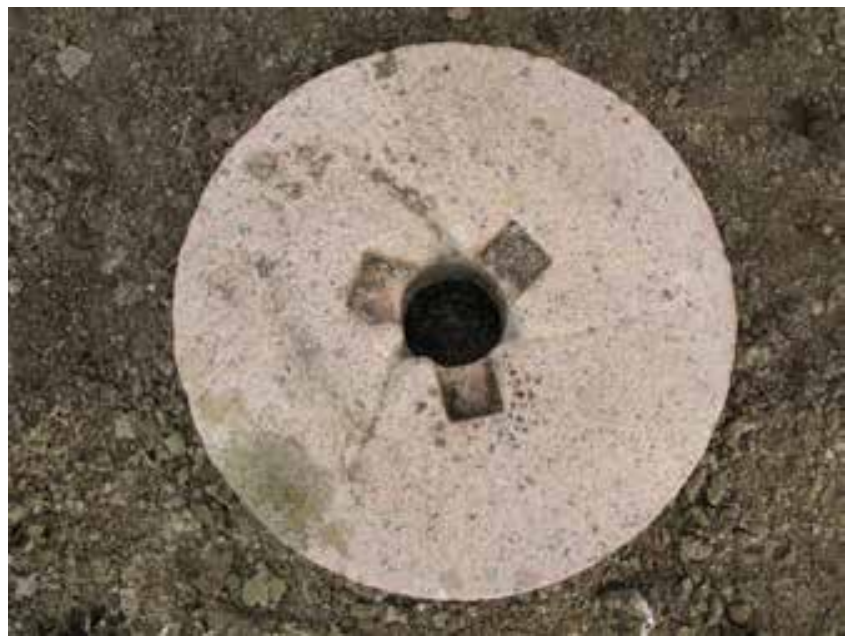

Figura 34 - Mó de Salto, SP, localizada em Paraibuna, no Vale do Paraíba. Fotografia do autor, 2012. 
No contexto dos pequenos moinhos que persistiram em suas lides através do século XX, cumpre destacar o relevante papel que os canteiros da cidade de Salto cumpriram no provimento de mós de boa qualidade. Tais peças são facilmente identificáveis pela cor rosada do granito de que são feitas, além de apresentarem, via de regra, formas e tamanhos padronizados. E respondem hoje pelo tipo de mós mais comumente encontradas nas zonas rurais de zona relativamente extensa. A principal razão da grande difusão das mós de Salto foi a presença da mão de obra especializada formada por canteiros imigrantes.

Ainda que a boa qualidade do granito-rosa seja conhecida desde os tempos coloniais na região, tendo sido ele empregado em muitas antigas fazendas das imediações, foi somente a partir do século XIX que a produção de peças de cantaria despontou. Com forte presença de imigrantes italianos, portugueses e espanhóis, o então distrito de Salto de ltu, onde imensos matacões de granito afloravam em pleno núcleo urbano, viu surgirem diversas oficinas e pedreiras (Figura 35). A maior parte dos canteiros de Salto eram imigrantes, a quem geralmente também pertenciam a maioria das oficinas ${ }^{133}$. Esses trabalhadores traziam da Europa uma forte tradição canteira cuja perícia e escala eram, até então, inéditas em São Paulo.

Através dessas considerações procurou-se estabelecer uma base mais ou menos consistente para uma classificação inicial das tipologias de mós encontradas no Estado de São Paulo. Assim, observando a Prancha V, podemos descrever os seguintes principais tipos de mós encontradas no território paulista:

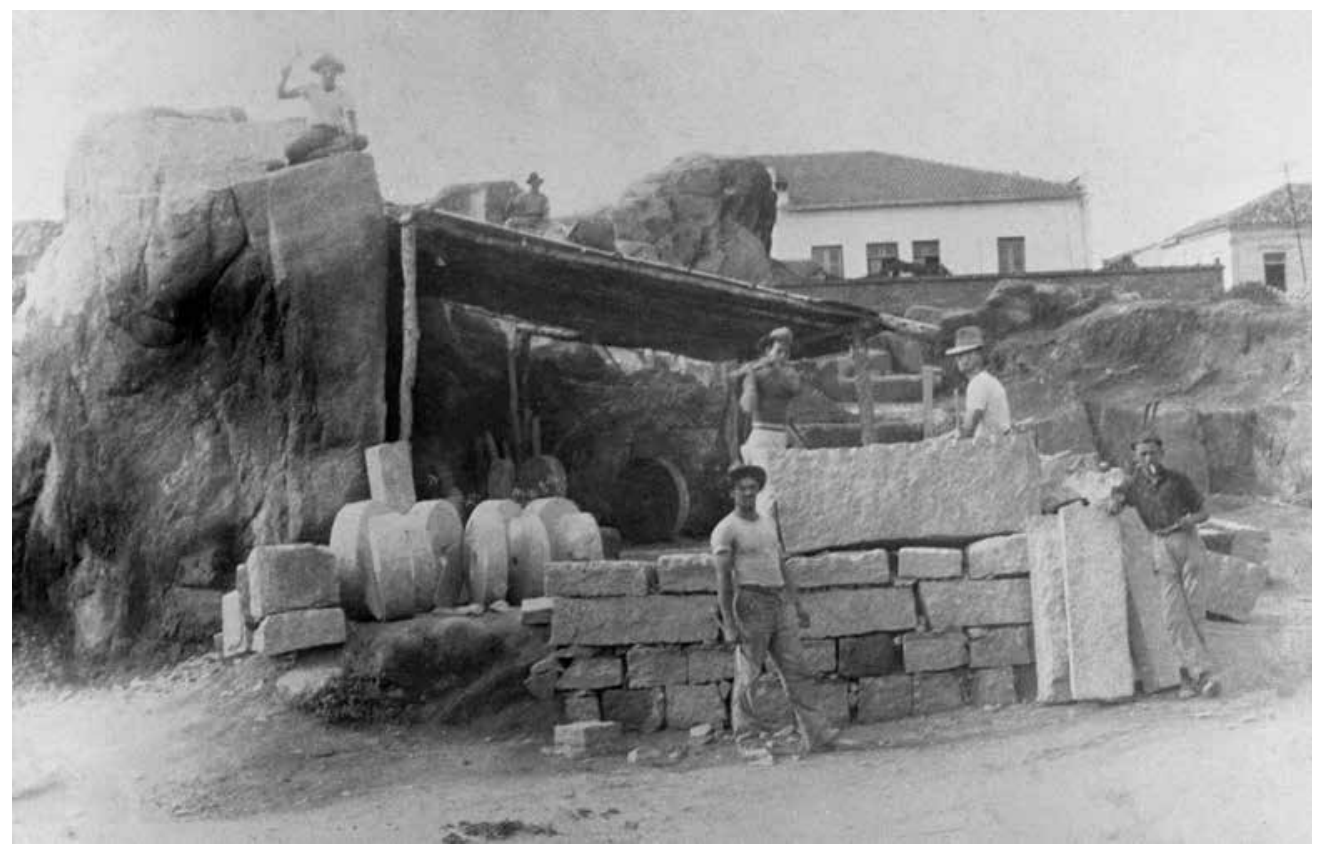

Figura 35 - Pedreira e oficina de cantaria no centro da cidade de Salto. Notar o conjunto de mós de diferentes tamanhos. Fotógrafo anônimo, 1921, negativo fotográfico, 5,5×5,5cm. Acervo do Museu da Cidade de Salto, Coleção Silvio Bologna.
133. Agradeço aqui a historiadora Gabriela Pontin Novaes, do Museu da Cidade de Salto, pelas informações sobre as oficinas de cantaria da cidade. 


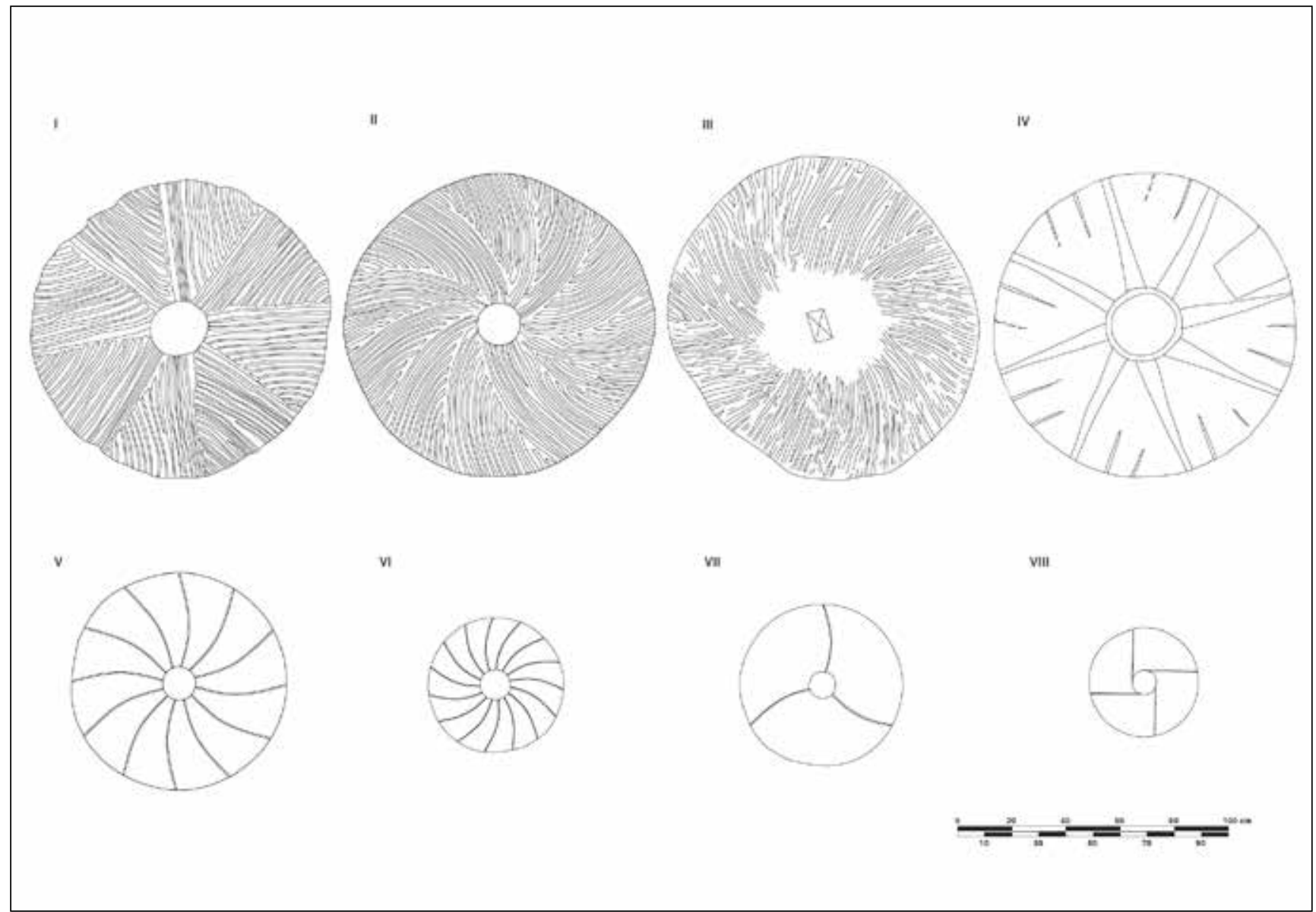

Prancha V - Principais tipos de mós encontradas no território paulista. Desenho de Walter Gagliardi Neto (2014),

I, II e III - São exemplos de mós utilizadas para a moagem do trigo. Não por acaso, estão localizadas todas nas proximidades da Região Metropolitana da Capital - área limítrofe do povoamento do planalto durante o século XVII, apogeu do cultivo do trigo em São Paulo.

IV, $V$ e VI - São essas mós utilizadas para a preparação do fubá de milho. Suas datações variariam entre o fim do século XVIII e a primeira metade do século XIX. Seriam exemplares bem antigos para essa tipologia, já que há indícios de que o fubá só ganhou importância na alimentação cotidiana em São Paulo com o aumento do fluxo de escravos africanos para a região da "serra-acima". As três mós foram encontradas na zona rural dos municípios de ltu e Piracicaba, região que concentrou a grande produção açucareira paulista do século XIX, alicerçada em grandes plantéis de escravos negros. Explica-se, desse modo, a presença incomum de doze $(\mathrm{V})$ ou quinze $(\mathrm{VI})$ mós de menores dimensões $(80$ e $50 \mathrm{~cm}$, respectivamente). 
VII e VIII - São essas pequenas mós de moinhos caipiras, localizadas ambas no Vale do Paraíba paulista. Além dos poucos sulcos, sua superfície é inteira trabalhada com o picão, comprovando o uso restrito para a fabricação do fubá de milho. Tais mós são as mais comuns em todo o interior do estado e facilmente identificáveis pela sua característica padronização de tamanho e material. São sempre feitas de granito-rosa, e seus diâmetros nunca se afastam dos dois, três ou quatro palmos. Sua padronização é um resultado típico da cultura organizacional europeia do trabalho artesanal. No contexto de forte urbanização da primeira metade do século XX, a produção de mós, nas oficinas de Salto, era um segmento dos mais desimportantes. Ainda assim, as peças de granito-rosa se espalharam pela ampla região que ia das zonas cafeicultoras de Ribeirão Preto e Araraquara até o Vale do Paraíba e sul de Minas Gerais.

Há que se acrescentar mais um tipo de mós nessa classificação, ainda que seja um tanto excêntrico: as mós vulcânicas importadas da Madeira e dos Açores. As "mós das llhas", como eram chamadas, eram feitas de basalto vulcânico - uma pedra facilmente identificável por sua extrema dureza, ainda que muito porosa, e de tom cinza-escuro (Figura 36). Essas pedras foram quase sempre limitadas ao Vale do Paraíba e a algumas antigas fazendas do litoral paulista, onde gozavam de um prestígio sem igual.

A razão de um apreço tão alto pelas mós das Ithas estaria no sabor mais acentuado do fubá por elas produzido. A composição extremamente rígida da rocha vulcânica impedia que a rotação das pedras soltasse partículas no fubá. Mesmo os mais resistentes granitos brasileiros não apresentam uma resistência tão eficaz ao atrito das mós.

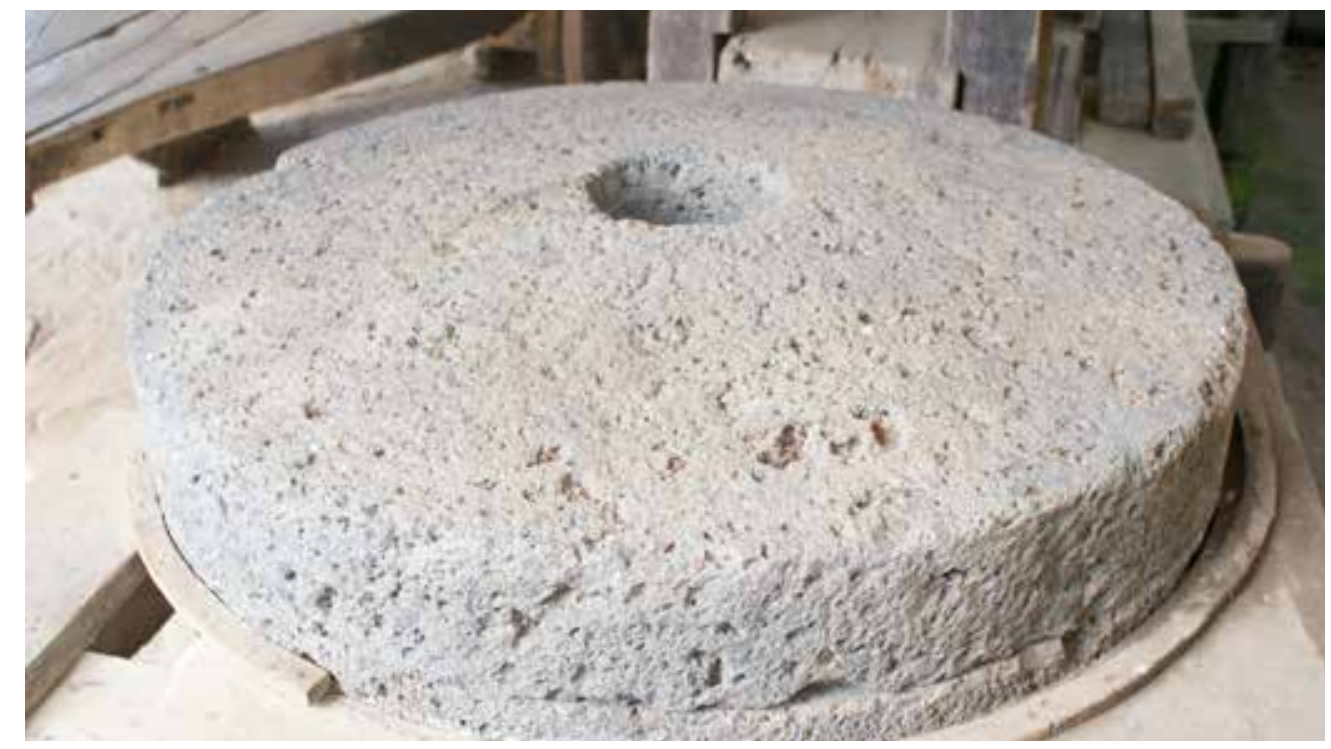

Figura 36 - Mó açoriana encontrada em um sítio de Bananal, SP. Fotografia do autor, 2013.

Annals of Museu Paulista. v. 23. n.1. Jan.-Jun. 2015. 
134. Cf. Almanak... (1871, p. 62, seção "Notabilidades"). As mós já eram fabricadas nos Açores em formas padrão de $1,1^{1 / 2}, 2,2^{1 / 2}, 3$, $3^{1 / 2}, 4,4^{1 / 2}, 5$ e $5^{1 / 2}$ palmos, tendo 4 ou 8 polegadas de altura.

135. Ver Luiz Cláudio M. Ribeiro (2006, p. 124-25).
A mó feita desse material começou a se fazer comum na segunda metade do século XIX, quando casas comerciais do Rio de Janeiro começaram a importá-las dos Açores. A partir de 1860, eram comuns anúncios feitos por casas comercias quando recebiam o carregamento encomendado. Na época, o seu uso principal, contudo, não estaria ligado à moagem do milho, mas sim ao despolpar do café. Conforme um anúncio de 1871 frisava, o despolpamento do fruto por meio de mós dos Açores era o melhor dos métodos, devido "ao lustre que apresenta, sem ter um só grão partido, livre de terra e mao cheiro"134. Ainda assim, outros usos poderiam ser feitos - principalmente o de moer o milho.

As décadas de 1860 e 1870, como ensina Luiz Claudio Ribeiro, foram o último momento em que técnicas de outros tempos se fizeram presentes no beneficiamento do café - o que, a partir dali, deu-se cada vez mais por novos e especializados maquinismos ${ }^{135}$. Quando sua utilização na produção do café viu-se obsoleta, as pedras açorianas voltaram-se exclusivamente para a moagem do milho.

É muito comum encontrá-las em moinhos ainda operantes no Vale do Paraíba. Em cidades como Bananal, Areias, São José do Barreiro, Vassouras, Barra do Piraí - lugares que prosperaram com o café nesse mesmo período - são mesmo bem comuns e ainda gozam de grande prestígio, até porque prescindem da repicagem.

\section{REFERÊNCIAS}

\section{FONTES PRIMÁRIAS IMPRESSAS}

ACTAS da câmara municipal da vila de São Paulo. São Paulo: Prefeitura Municipal, 1914. Vols. I, II e III.

CARTAS de datas de terra. São Paulo: Departamento de Cultura da Prefeitura Municipal, 20 vols. (1937-1940).

INVENTÁRIOS e testamentos: papéis que pertenceram ao $1^{\circ}$ Cartório de Órfãos da capital. São Paulo: Arquivo do Estado. 47 vols. (1920-1997).

SAIA, Luiz. A aldeia de Carapicuíba. Texto datilografado pertencente ao acervo da $9^{\text {a }}$ SR do IPHAN.

\section{LIVROS, ARTIGOS E DISSERTAÇÕES}

ABREU, Mauricio de Almeida. Geografia histórica do Rio de Janeiro, 1502-1700. Rio de Janeiro: Andrea Jakobsson Estúdio; Prefeitura do Rio de Janeiro, 2010.

AB'SABER, Aziz Nacib. Os domínios de natureza no Brasil: potencialidades paisagísticas. São Paulo: Ateiliê Editorial, 2003. 
ABULAFIA, David (Ed). The Mediterranean in History. Londres: Thames \& Hudson, 2003.

ALMEIDA, Aluísio de. Vida e morte do tropeiro. Rio de Janeiro: Martins, 1971.

ALVES, Adriana. Petrogênese de plútons graníticos do leste paulista: geocronologia, geoquímica elemental e isotópica. Tese (Doutorado) - Instituto de Geociências, Universidade de São Paulo, São Paulo, 2009.

ANDRADE, Francisco de Carvalho Dias de. A memória das máquinas: um estudo de história da técnica em São Paulo. Dissertação (Mestrado) - Instituto de Filosofia e Ciências Humanas, Universidade Estadual de Campinas, Campinas, 2011.

As ruínas do Sítio do Morro: um importante moinho de trigo da era das bandeiras. In: Arquitextos: Vitruvius, São Paulo, ano 14, n. 167.02, abr. 2014. Disponível em: < http://www. vitruvius.com.br/revistas/read/arquitextos/14.167/5182>.

ANDRADE, Francisco de Paula Dias de. Subsídios para o estudo da influência da legislação na ordenação e na arquitetura das cidades brasileiras. Tese (Doutorado) -Escola Politécnica, Universidade de São Paulo, São Paulo, 1966.

ARAÚJO, Emanoel. Arte, adorno, design e tecnologia no tempo da escravidão. São Paulo: Via Impressa, 2013.

BANDEIRA, Julio; LAGO, Pedro Corrêa do. Debret e o Brasil: obra completa, 1816-1831. Rio de Janeiro: Capivara, 2009.

BARROS, Manuel de Souza. Cercas nordestinas: traços ecológicos do sertão pernambucano. Recife: Secretaria de Educação e Cultura, 1985.

BASSO, Rafaela. Alimentação e sociedade: a vila de São Paulo, século XVII. In: Reunião Anual da SBPC, 60. Campinas, Anais...: Unicamp, Campinas, 2008.

A cultura alimentar paulista: uma civilização do milbo?. Dissertação (Mestrado) Instituto de Filosofia e Ciências Humanas, Universidade Estadual de Campinas, Campinas, 2011.

BÍBLIA de Jerusalém. São Paulo: Paulus, 2002.

BLAJ, Ilana. A trama das tensões: o processo de mercantilização de São Paulo colonial, 16811721. São Paulo: Humanitas; FAPESP, 2002.

BLOCH, March. Apologia da história, ou o ofício do historiador. Rio de Janeiro: Jorge Zahar Edições, 2001.

BRAUDEL, Fernand. Civilização material, economia e capitalismo: as estruturas do cotidiano. São Paulo: Martins Fontes, 1995.

CARRARA, Angelo A. Minas e currais: produção rural e mercado interno de Minas Gerais, 1674-1807. Juiz de Fora, MG: Ed. UFJF, 2007.

CARDIM, Fernão. Tratados da terra e da gente do Brasil. Lisboa: Comissão Nacional para as Comemorações dos Descobrimentos Portugueses, 1997. 
CARVAlHO, Maria C. W. (Ed.) Caminhos do Rio a Juiz de Fora. São Paulo: Marcos Carrilho Arquitetos, 2008.

CASTRO, Josué de. Ensaios de geografia humana. São Paulo: Brasiliense, 1966.

COROMINAS, Joan de. Diccionário crítico etimológico de la lengua castellana. Madri: Gredos, $1954.5 \mathrm{v}$.

COSTA, Antonio G. (Ed.). Os caminhos do ouro e a Estrada Real. Belo Horizonte: Ed. UFMG; Lisboa: Kapa, 2005.

EVANS, Oliver. The Young Mill-Wright and Miller's Guide. Filadélfia: M. Carey \& Son, 1821.

FLANDRIN, Jean-Louis; MONATANRI, Massimo. História da alimentação. São Paulo: Estação Liberdade, 1998.

FONSECA, Manuel da. Vida do venerável padre Belchior de Pontes da Companbia de Jesus da província do Brasil. São Paulo: Companhia Melhoramentos, 1932.

FRAGOSO, João Luis. Homens de grossa aventura: acumulação e hierarquia na praça mercantil do Rio de Janeiro, 1790-1830. Rio de Janeiro: Arquivo Nacional, 1992.

FREYRE, Gilberto. Nordeste: aspectos da influência da cana sobre a vida e paisagem do nordeste do Brasil. Rio de Janeiro: José Olympio, 1967.

FRIEDMAN, John Block; FIGG, Kristen Mossler. Trade, Travel, and Exploitation in Middle Ages: an Encyclopedia. Nova York: Routledge, 2000.

GALIL, Jacob; EISIKOWITCH, Dan. Flowering Cycles and Fruit Types of Ficus sycomorus in Israel. New Phytologist, Cambridge, v. 67, n. 3, 1968, p. 745-758.

GAMA, Ruy. Glossário. São Paulo: Fupam; FAU-USP, 1982.

Engenho e tecnologia. São Paulo: Livraria Duas Cidades, 1978.

GIBB, Hamilton Alexander Rosskeen (Ed.) Encyclopaedia of Islam. Londres: Brill, 1960. 28 v.

GOULART, José Alípio. Transportes nos engenhos de açúcar. Rio de Janeiro: Taveira, 1959.

Tropas e tropeiros na formação do Brasil. Rio de Janeiro: Conquista, 1961.

HASUI, Yociteru. Geologia da Folha São Roque. Boletim do Instituto de Geociências, São Paulo, v. 6, p. 157-183, 1975.

HOLANDA, Sérgio Buarque de. Caminhos e fronteiras. Rio de Janeiro: José Olympio, 1957.

KATINSKY, Júlio Roberto. Glossário dos carpinteiros de moinhos. In: GAMA, Ruy (Org.) História da técnica e da tecnologia: textos básicos. São Paulo: Edusp, 1985.

KLEIN, Herbert S. The supply of Mules to Central Brazil: the Sorocaba Market, 1825-1880. Agricultural History, Berkeley, v. 64, n. 4, p. 1-25, 1990. 
LANGDON, John. Mills in the Medieval Economy: England, 1300-1540. Nova York: Oxford Press University, 2004.

LEAL, João. Etnografias portuguesas, 1870-1970: cultura popular e identidade nacional. Lisboa: Dom Quixote, 2000.

LEITE, Serafim. História da Companbia de Jesus no Brasil. Belo Horizonte: Itatiaia, 2000.

LEME, Pedro Taques de A. Paes. Historia da capitania de S. Vicente. São Paulo: Editora Melhoramentos, [s.d.].

LINHARES, Maria Yedda de; SILVA, Francisco Carlos Teixeira da. História da agricultura brasileira: combates e controvérsias. São Paulo: Brasiliense, 1981.

LORENZ, Wayne; WOLFRAM, Phillip. The Millstones of Barbegal. Civil Engineering, Londres, v. 77 , n. 6 , p. $62-67$, jun. 2007.

LUCAS, Alfred. Ancient Egyptian Materials and Industries. Londres: Kessinger Publishing. 2003.

LUCCOCK, John. Notas sobre o Rio de Janeiro e partes meridionais do Brasil. São Paulo: Livraria Martins, 1942.

MACEDO, Jozé Norberto. Fazendas de gado no vale do São Francisco. Rio de Janeiro: Serviço de Publicação Agrícola, 1952.

MARQUES, A. H. Oliveira. Introdução à história da agricultura em Portugal. Lisboa: Cosmos, 1968.

MARQUESE, Rafael Bivar. Administração e escravidão: ideias sobre a gestão da agricultura escravista no Brasil. São Paulo: Hucitec, 2010.

MAWE, John. Viagens ao interior do Brasil. Rio de Janeiro: Zélio Valverde, 1944.

MENDONÇA, Antonio Manuel de. Memória econômico política da capitania de São Paulo, 1800. Anais do Museu Paulista, São Paulo, t. XV, p. 81-247, 1961. Série antiga.

MENESES, José Newton Coelho. O continente rústico: abastecimento alimentar nas Minas Gerais setecentistas. Diamantina, MG: Maria Fumaça, 2000.

MERI, Josef W. Medieval Islamic Civilization: an Encyclopedia. Nova York: Routlegde, 2006. $2 \mathrm{v}$.

MONTEIRO, John. Negros da terra: índios e bandeirantes nas origens de São Paulo: São Paulo: Companhia das Letras, 1994.

MOTA, Mauro, et. al. O bode no Nordeste. Recife: IJNPS, 1969.

OLIVEIRA, Ernesto Veiga de; GALHANO, Fernando; PEREIRA, Benjamim. Tecnologia tradicional portuguesa: sistemas de moagem. Lisboa: INIC, Centro de Estudos de Etnologia, 1983. 
OLIVEIRA, Sebastião Almeida. Folclore e outros temas. Limeira, SP: Gazeta de Limeira, 1948.

PLINY, the Elder. Natural History. Cambridge: University Press, 1986. $10 \mathrm{v}$.

PRADO JR., Caio. Formação do Brasil contemporâneo: colônia. São Paulo: Brasiliense, 1942.

PUNTONI, Pedro. A guerra dos bárbaros: povos indígenas e a colonização do sertão nordeste do Brasil, 1650-1720. São Paulo: FAPESP/Hucitec, 2002.

QUEIROZ, Maria Isaura Pereira de. Bairros rurais paulistas. São Paulo: Livraria Duas cidades, 1973.

REIS FILHO, Nestor Goulart. São Paulo: vila, cidade, metrópole. São Paulo: Bank of Boston, 2004.

RIBEIRO, Luiz Cláudio M. A invenção como ofício: as máquinas de preparo e benefício do café no séc. XIX. Anais do Museu Paulista: história e cultura material, São Paulo, v. 14, n. 1, jun. 2006.

ROSENTHAL, Franz. The Classical Heritage in Islam. Nova York: Routledge, 1994.

SANCHES, Marcos Guimarães. Sertão e fazenda: ocupação e transformação da serra fluminense entre 1750 e 1820. Revista do Instituto Histórico e Geográfico Brasileiro, Rio de Janeiro, v. 151, n. 366, p. 1-96, jan./mar. 1990.

SCHMIDT, Carlos Borges. O meio rural: investigações e estudos das suas condições sociais e económicas. São Paulo: Secretaria de Agricultura, Indústria e Comércio do estado de São Paulo. 1946.

SCHMIDT, Carlos Borges. O pão da terra. São Paulo: Arquivo Municipal da Cidade de São Paulo, 1956.

. O milho e o monjolo: aspectos da civilização do milho, técnicas, utensílios e maquinaria tradicionais. Rio de Janeiro: Ministério da Agricultura, Serviço de Informação Agrícola, 1967.

SCHWARTZ, Stuart B. Segredos internos: engenhos e escravos na sociedade colonial 15501835. São Paulo: Companhia das Letras, 1988.

SERRÃO, Joel; MARQUES, A. H. Oliveira (Dir.). Nova história de Portugal: das invasões germânicas a reconquista. Lisboa: Presença, 1993.

SOUZA, Bernardino José de. Ciclo do carro de bois no Brasil. São Paulo: Companhia Editora Nacional, 1958.

SOUZA, Laura de Mello e. Formas provisórias de existência: a vida cotidiana nos caminhos, nas fronteiras e nas fortificações. In: História da vida privada no Brasil: cotidiano e vida privada na América portuguesa. São Paulo: Companhia das Letras, 1997.

STRAFORINI, Rafael. No caminho das tropas. Sorocaba, SP: TCM, 2001.

THEOPHRASTUS, Enquiry into Plants, and Minor Works on Odours and Weather Signs. Cambridge: Harvard University Press, 1990. 2 v. 
TRINDADE, Jaelson Bitran. O agro ituano. In: TOSCANO, Walter (Org.). Diagnóstico geral da cidade de Itu para implantação de um programa de ação cultural. São Paulo: Condephaat, 1980. $4 \mathrm{v}$.

TRINDADE, Jaelson Bitran; URBAN, João. Tropeiros. São Paulo: Editoração Publicações e Comunicações, 1992.

USHER, Abbott Payson. Uma história das invenções mecânicas. Campinas, SP: Papirus, 1993.

VIDE, Sebastião Monteiro da. Constituições Primeiras do Arcebispado da Babia. São Paulo: Edusp, 2010.

VILARDARGA, José Carlos. São Paulo na órbita do Império dos Felipes: conexões castelhanas de uma vila da América Portuguesa durante a União Ibérica, 1580-1640. 2010. Tese (Doutorado em História Social) - Faculdade de Filosofia, Letras e Ciências Humanas, Universidade de São Paulo, São Paulo. 2011.

WERNECK, Luís Peixoto L. Breves considerações sobre a posição atual da lavoura do café. Almanak administrativo, mercantil e industrial do Império do Brasil para o anno de 1855, Rio de Janeiro, 1855.

ZALA, Francisco Javier Goicolea. Azudes, molinos y otros aspectos de "los veintíun libros de los ingenios y máquinas”. Revistas de Obras Públicas, Madri, n. 3.396, p. 59-68, mar. 2000.

Artigo apresentado em 06/04/2015. Aprovado em 17/05/2015. 